\title{
APLICAÇÃO DE UM SISTEMA DE CLASSIFICAÇÃO DE CARCAÇAS E CORTES E EFEITO PÓS ABATE DA QUALIDADE DE CORTES DE FRANGO CRIADOS NO SISTEMA ALTERNATIVO
}

\author{
MóNICA BEATRIz AlVARAdo HuALLANCo
}

\begin{abstract}
Dissertação apresentada à Escola Superior de Agricultura “Luiz de Queiroz”, da Universidade de São Paulo, para obtenção do titulo de Mestre em Ciências, Área de concentração: Ciência e Tecnologia de Alimentos.
\end{abstract}

P I R A C I C A B A

Estado de São Paulo - Brasil

Dezembro - 2004 


\title{
APLICAÇÃO DE UM SISTEMA DE CLASSIFICAÇÃO DE CARCAÇAS E CORTES E EFEITO PÓS ABATE DA QUALIDADE DE CORTES DE FRANGO CRIADOS NO SISTEMA ALTERNATIVO
}

\section{MÓNICA BEATRIz AlVARAdo HuALLANCO}

Engenheira Química

Orientadora: Profa. Dra. MARTA HELENA FILLET SPOTO

\begin{abstract}
Dissertação apresentada à Escola Superior de Agricultura "Luiz de Queiroz", da Universidade de São Paulo, para obtenção do titulo de Mestre em Ciências, Área de concentração: Ciência e Tecnologia de Alimentos.
\end{abstract}

P I R A C I C A B A

Estado de São Paulo - Brasil

Dezembro - 2004 


\section{Dados Internacionais de Catalogação na Publicação (CIP)}

DIVISÃO DE BIBLIOTECA E DOCUMENTAÇÃO - ESALQ/USP

\section{Alvarado Huallanco, Mónica Beatriz}

Aplicação de um sistema de classificação de carcaças e cortes e efeito pós abate da qualidade de cortes de frango criados no sistema alternativo / Mónica Beatriz Alvarado Huallanco. - - Piracicaba, 2004.

$82 \mathrm{p}$.

Dissertação (Mestrado) - - Escola Superior de Agricultura Luiz de Queiroz, 2004.

Bibliografia.

1. Abate 2. Análise de alimento 3. Análise sensorial 4. Bioquímica de alimento 5. Carcaça 6. Classificação 7. Corte de alimentos 8. Frango de corte 9. Qualidade I. Título

CDD 664.93

\section{"Permitida a cópia total ou parcial deste documento, desde que citada a fonte - O autor"}


A meus pais
Elard e Nora
pela vida, amor, incentivo e apoio

A meus irmãos

Elard, Patrícia e Erick

A Fernandita

pelo carinho e apoio 


\section{AGRADECIMENTOS}

À Profa. Dra. Carmen J. Contreras Castillo, pela amizade, orientação e incentivo fundamental para a realização deste trabalho.

À Escola Superior de Agricultura “Luiz de Queiroz” (ESALQ/USP), em especial ao Departamento de Agroindústria, Alimentos e Nutrição pela oportunidade para a realização deste trabalho.

Aos professores, funcionários e estagiários pelo carinho, amizade e colaboração na realização deste trabalho.

Ao CTC-ITAL, que permitiu a utilização de seus equipamentos para a realização deste trabalho.

A Korin Agropecuária Ltda e FRICOK, pela doação dos frangos para a realização deste trabalho.

A Ana Paula pela amizade e colaboração na realização deste trabalho.

E a todas as pessoas que diretamente ou indiretamente colaboraram para a realização deste trabalho. 


\section{SUMÁRIO}

Página

LISTA DE FIGURAS . . . . . . . . . . . . . . . . . . . . viii

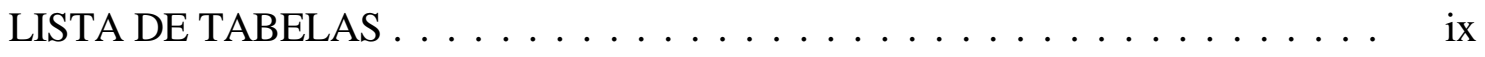

LISTA DE QUADROS . . . . . . . . . . . . . . . . . . . xi

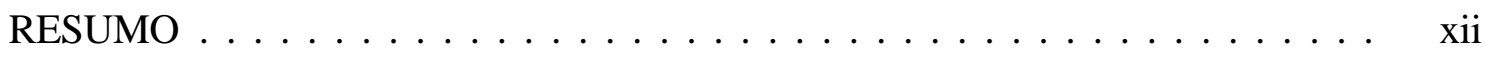

SUMMARY ........................ xiv

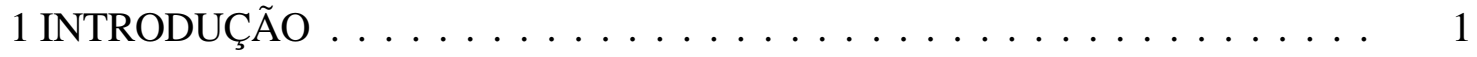

2 REVISÃO DE LITERATURA . . . . . . . . . . . . . . . . . . . . . 4

2.1 A avicultura Brasileira no mundo . . . . . . . . . . . . . . . . . . 4

2.2 A avicultura Brasileira . . . . . . . . . . . . . . . . . . . . 4

2.2.1 Sistema industrial ou convencional . . . . . . . . . . . . . . . 4

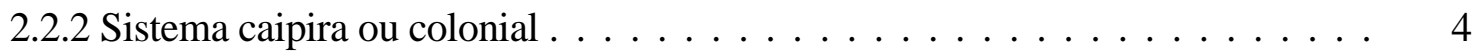

2.2 .3 Sistema alternativo . . . . . . . . . . . . . . . . 5

2.2.4 Sistema orgânico ou agro-ecológico . . . . . . . . . . . . . . 5

2.3 Classificação de carcaças e cortes de frango . . . . . . . . . . . . . 5

2.4 Atributos de qualidade da carne de frango $\ldots \ldots \ldots \ldots$

2.4 .1 Aparência . . . . . . . . . . . . . . . . . . . . . . . 12

2.4 .2 Textura $($ maciez $) \ldots \ldots \ldots \ldots \ldots \ldots$

2.4 .3 Sabor e aroma . . . . . . . . . . . . . . . . . . . . 17

3 MATERIAL E MÉTODOS . . . . . . . . . . . . . . . . . . 25

3.1 Classificação das carcaças e cortes . . . . . . . . . . . . . . . 25

3.1 .1 Conformação . . . . . . . . . . . . . . . . . . . . . 25

3.1 .2 Conteúdo de carne . . . . . . . . . . . . . . . . . . 26

3.1.3 Depósito e cobertura de gordura . . . . . . . . . . . . . . . 26 
3.1.4 Depenagem e resíduos de pele . . . . . . . . . . . . . . . . . . 30

3.1.5 Carne exposta, cortes, dilaceramento e ossos quebrados . . . . . . . . . . . . 30

3.1.6 Descolorações na pele, manchas e hematomas na carne . . . . . . . . . . . 30

3.2 Avaliação de atributos de qualidade . . . . . . . . . . . . . . . . . 33

3.2.1 Determinação do rendimento $\ldots \ldots \ldots \ldots \ldots$

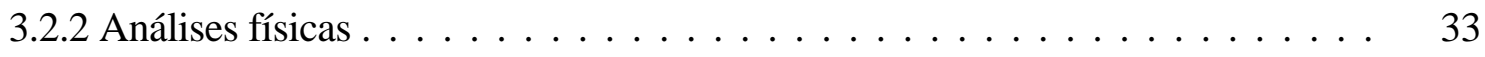

3.2.2.1 Cor instrumental . . . . . . . . . . . . . . . . . . . . 33

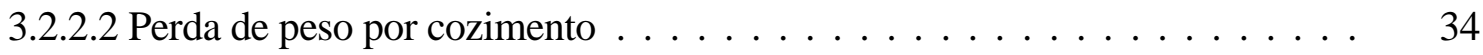

3.2.2.3 Força de cisalhamento . . . . . . . . . . . . . . . . . . . . . . 34

3.2.2.4 Capacidade de retenção de água (CRA) . . . . . . . . . . . . . . . . 35

3.2.3. Análises químicas . . . . . . . . . . . . . . . . . . . . . 35

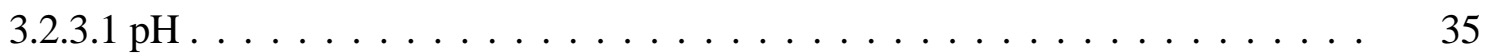

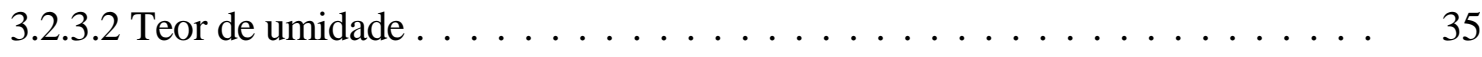

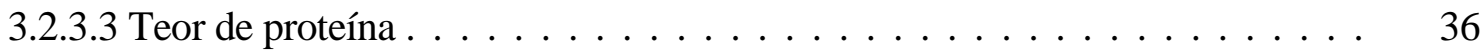

3.2.3.4 Teor de lipídeos . . . . . . . . . . . . . . . . . . . . . . 36

3.2 .3 Avaliação sensorial . . . . . . . . . . . . . . . . . . . . . . 36

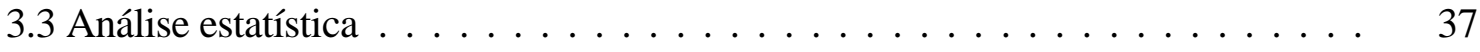

4 RESULTADOS E DISCUSSÃO . . . . . . . . . . . . . . . . . 38

4.1 Classificação de carcaças e cortes de frango . . . . . . . . . . . . . . . 38

4.1.1 Carcaças de frango . . . . . . . . . . . . . . . . . . . . . 38

4.1 .2 Cortes de frango . . . . . . . . . . . . . . . . . . 42

4.2 Avaliação de atributos de qualidade . . . . . . . . . . . . . . . . . 46

4.2 .1 Rendimento de carcaças . . . . . . . . . . . . . . . . . . . . . 46

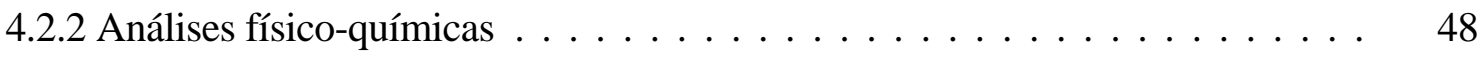

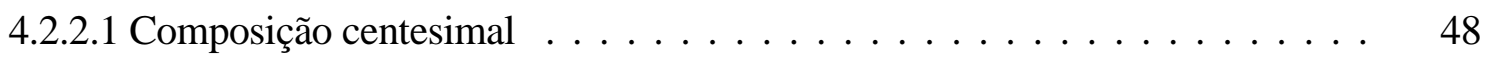

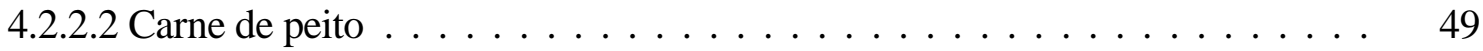

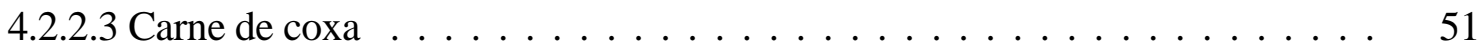

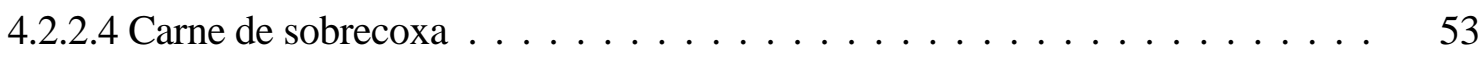

4.2 .3 Análise sensorial . . . . . . . . . . . . . . . . . . . . . 54 
4.2.4 Relação entre atributos de qualidade físico-químicas e análise sensorial . . . . . 56

5 CONCLUSÕES . . . . . . . . . . . . . . . . . . . . 66

REFERÊNCIAS BIBLIOGRÁFICAS . . . . . . . . . . . . . 68 


\section{LISTA DE FIGURAS}

Página

1 Amostragem das carcaças na linha após a depenagem . . . . . . . . . . . . . . 27

2 Amostragem dos cortes na área de cortes . . . . . . . . . . . . . . 27

3 Medição de defeitos com o gabarito de medições . . . . . . . . . . . . . . . . . . . 27

4 Gabarito de medições $(\mathrm{cm}) \ldots \ldots \ldots \ldots \ldots \ldots$

Gabarito de medições $(\mathrm{cm})$, continuação . . . . . . . . . . . . . . . . . . . . 29

5 Classificação de carcaças de frango . . . . . . . . . . . . . . . . . . . . 40

6 Classificação de corte de peito . . . . . . . . . . . . . . . . . . 43

7 Classificação de corte de coxa . . . . . . . . . . . . . . . . 43

8 Distribuição da porcentagem de água absorvida . . . . . . . . . . . . . . . . . . 47

9 Análise de correspondência para carne de peito . . . . . . . . . . . . . . . . . . 61

10 Análise de correspondência para carne de coxa . . . . . . . . . . . . . . . . . . 61

11 Análise de correspondência para carne de sobrecoxa . . . . . . . . . . . . . . . 62

12 Análise de correspondência das análises de carne de peito, coxa e sobrecoxa . . . 62 


\section{LISTA DE TABELAS}

Página

1 Defeitos encontrados nas carcaças de frango . . . . . . . . . . . . . . 39

2 Predição dos membros do grupo para classificação de carcaças (p < 0,05) . . . . 41

3 Defeitos encontrados nos cortes de frango $(\%) \ldots \ldots \ldots$. . . . . . . . . . 42

4 Predição dos membros do grupo para classificação de corte de peito $(p<0,05)$. 44

5 Predição dos membros do grupo para classificação de corte de coxa $(\mathrm{p}<0,05)$. 44

6 Predição dos membros do grupo para classificação de corte de sobrecoxa

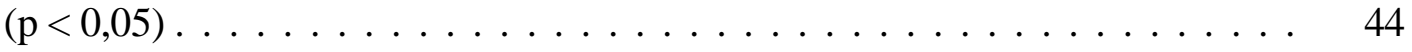

7 Predição dos membros do grupo para classificação de corte de peito $(p<0,05)$. 45

8 Predição dos membros do grupo para classificação de corte de coxa $(\mathrm{p}<0,05)$. 45

9 Valores médios dos pesos (g) medidos durante o abate e do rendimento (\%) . . . 46

10 Valores médios da composição centesimal de carne de frango de criação

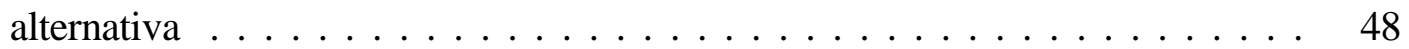

11 Análises físico-químicas da carne de peito . . . . . . . . . . . . . . . 49

12 Análises físico-químicas da carne de coxa . . . . . . . . . . . . . . . 52

13 Análises físico-químicas da carne de sobrecoxa . . . . . . . . . . . . . . . 53

14 Médias e significância $(\mathrm{p}<0,05)$ da análise sensorial da carne de peito . . . . . 54

15 Médias e significância $(\mathrm{p}<0,05)$ da análise sensorial da carne de coxa . . . . . 55 
16 Médias e significância $(\mathrm{p}<0,05)$ da análise sensorial da carne de sobrecoxa . . . 55

17 Análise de correlação simples de Pearson para a carne de peito . . . . . . . . . . . 57

18 Análise de correlação simples de Pearson para a carne de coxa . . . . . . . . . . . 59

19 Análise de correlação simples de Pearson para sobrecoxa . . . . . . . . . . . . . . 59

20 Valores médios das análises físicas e sensoriais dos cortes de carne de frango

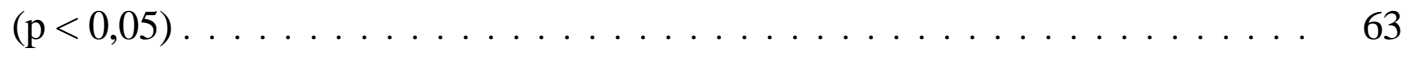




\section{LISTA DE QUADROS}

Página

1 Classificação de carcaças de frango . . . . . . . . . . . . . . . . . 31

2 Classificação de cortes de frango . . . . . . . . . . . . . . . . . 32 


\title{
APLICAÇÃO DE UM SISTEMA DE CLASSIFICAÇÃO DE CARCAÇAS E CORTES E EFEITO DO TEMPO PÓS ABATE NA QUALIDADE DA CARNE DE FRANGOS CRIADOS NO SISTEMA ALTERNATIVO
}

\author{
Autora: MÓNICA BEATRIZ ALVARADO HUALLANCO \\ Orientadora: Prof $^{\mathrm{a}}$.Dr ${ }^{\mathrm{a}}$. MARTA HELENA FILLET SPOTO
}

\section{RESUMO}

A qualidade da carne envolve aspectos estéticos, avaliados pelo consumidor e físicoquímicos importantes para o processador, os quais podem ser controlados nas diversas etapas de produção. Na primeira fase, a fim de determinar a qualidade de carcaças e cortes aplicou-se um sistema de classificação, os quais foram avaliados na aparência (conformação, conteúdo de carne, cobertura de gordura, depenagem, carne exposta e corte, ossos quebrados, descolorações e hematomas) e classificados em níveis A, B ou C, decrescendo de nível conforme os defeitos se apresentaram, além analisou-se a capacidade de retenção de água (CRA), para esta fase utilizou-se à análise discriminante e análise de variância. Na segunda fase, foram avaliados os atributos de qualidade (cor, pH, CRA, força cisalhamento, perda de peso por cozimento, composição centesimal, análise sensorial) dos cortes de peito, coxa e sobrecoxa às 5, 24, 48 e 72 horas pós abate, para frangos criados no sistema alternativo. Para análise dos resultados foram utilizadas as análises de médias, regressão múltipla, correlação simples de Pearson e correspondência para os atributos físico-químicos e sensoriais. Na classificação foram avaliadas 301 carcaças e 146, 147 e 145 de cortes de peito, coxa e sobrecoxa respectivamente. Das carcaças analisadas, 79,73\% apresentaram algum grau de contusão, sendo que $65,78 \%$ destas eram de grau leve, dessa forma, foram classificadas como tipo A. Fazendo uso da análise discriminante, 84,9\% das 
carcaças mostraram-se corretas quanto à classificação utilizada, apresentando diferença significativa entre as classes. Os outros defeitos foram arranhões, corte de pele, depenagem, resíduo de pele, fraturas ou ossos quebrados. Quanto aos cortes (peito, coxa e sobrecoxa), a maioria foi classificada na categoria A. Os cortes de peito, coxa e sobrecoxa apresentaram 87,7, 96,2 e 95\% das amostras corretamente classificadas, respectivamente. Foi realizada na análise de CRA para peito e coxa, observando-se que o corte da coxa classificada como A apresentou maior valor de CRA comparada com o tipo C. Na avaliação da qualidade dos cortes de peito, coxa e sobrecoxa, verificou-se o comportamento da carne nas características físico-químicas em quatro períodos distintos: 5, 24, 48 e 72 horas após o abate. Com o decorrer do tempo de maturação, no peito observou-se um aumento no valor de L* e um decréscimo da força de cisalhamento da carne de peito, melhorou a qualidade promovendo um amaciamento da carne, entretanto, para a coxa não apresentou mudanças na qualidade com o decorrer do tempo, apenas foi observado um acréscimo no valor a*, porém a sobrecoxa a partir de 48 horas, os efeitos da proteólise do músculo influenciaram um aumento significativo na perda de peso inversamente ao CRA. Quanto à análise sensorial, não houve diferença entre o frango alternativo e convencional e nem entre as horas pós abate para os três cortes. Também foram realizadas as análises de correlação simples de Pearson e correspondência para os atributos físico-químicos e sensoriais.

PALAVRA CHAVES: frango, criação alternativa, classificação, qualidade. 


\title{
CARCASSES AND CUTS CLASSIFICATION SYSTEM AND THE EFFECTS OF TIME AFTER SLAUGHTERING ON THE QUALITY OF MEAT FROM CHICKEN RAISED ON NATURAL SYSTEM
}

\author{
Author: MÓNICA BEATRIZ ALVARADO HUALLANCO \\ Adviser: Prof ${ }^{\mathrm{a}}$.Dr ${ }^{\mathrm{a}}$. MARTA HELENA FILLET SPOTO
}

\section{SUMMARY}

Meat quality is related to a esthetical aspects, which are evaluated by the consumer, and to physiochemical aspects, which are important to the meat processor. These aspects can be controlled at the various steps during production. In the first phase of this study, aiming at evaluating carcasses and cuts, a grading system was used by which meat appearance (conformation, fleshing, fat covering, feathers, exposed flesh and cuts, broken bones, skin discoloration and bruises) was evaluated. They were grading in $\mathrm{A}, \mathrm{B}$ and $\mathrm{C}$ class, according to defects, besides analyzing a water holding capacity (WHC), in this phase a discriminant and variance analyses were utilized. In the second phase, the attributes quality (colour values, $\mathrm{pH}$, WHC, shear force, cooking loss, chemical composition, sensory analyses) of breast, drumstick and thigh cuts, from chicken raised in natural system, was evaluated 5, 24, 48 and 72 hours after slaughtering. In order to analyze the results, the following were used: analysis of means, multiple regression, Pearson's simple correlation and the relationship with the physicochemical and sensorial parameters. At grading, a total of 301 carcasses and 146,147 and 145 breasts, drumsticks and thigh broilers, respectively, were evaluated. The results indicated that $79,73 \%$ of the carcasses contained some degree of bruise and 
that $65,78 \%$ contained light bruise, thus being classified as class A. Results of the discriminant analysis showed that $84,9 \%$ of the carcasses was correctly graded, showing significant difference among the classes. Other defects found were scratches, skin cuts, feathers and skin residue, fractured and broken bones. Breast, thigh and drumstick cuts had 87,7, 96,2 and 95,0\% of samples correctly graded, respectively. A C analysis was done for breast and drumstick, showing that the drumstick classified as class A had a higher WHC value compared to class C. At the breasts, drumsticks and thigh broilers evaluation, the physiochemical behavior of the meat was studied in four different periods: 5, 24, 48 and 72 hours after slaughtering. During the aging period, an increase in the $\mathrm{L}^{+}$value and a decrease in the shear force of the breast meat were observed, resulting in a quality improvement by meat softening. The drumstick did not show changes in quality, and only an increase in the value a* was observed. However, the thigh showed a significant increase on the weight loss inversely to the WHC, due to the effects of the muscle proteolysis. The sensorial analysis for the three cuts no significant difference between both the natural and conventional chicken and the time after slaughtering was observed.

KEYWORDS: chicken, natural raising, classification, quality. 


\section{INTRODUÇÃO}

Há fortes evidencia da demanda por alimentos naturais e saudáveis por parte dos consumidores, um exemplo é a demanda de produtos isentos de resíduos químicos. A tendência é que os compradores busquem produtos de empresas capazes de demostrar programas de saúde que não dependam de antibióticos, tem favorecido a criação orgânica. Desenvolvimento de animais saudáveis, com maior padrão de bem-estar animal e com resultado de produtos de maior qualidade (Sundrum, 2001).

Não existe literatura no Brasil, até o momento, sobre medidas da qualidade do frango alternativo, mas alguns consumidores reportam diferenças em relação ao frango convencional, na maciez, sabor e odor. Assim, existe a necessidade de estudos medindo objetivamente essas e outras características de qualidade.

A produção de carne sempre foi uma importante atividade na economia brasileira, de tal forma que nos últimos anos vêm-se incrementado, e hoje o Brasil é um dos maiores produtores e exportadores de carne de frango ao nível mundial (ABEF, 2004).

As exigências pela qualidade da carne são cada vez maiores tanto no mercado internacional como no nacional, o consumidor está mais ciente dos atributos de qualidade da carne. Essas exigências provocaram mudanças que tiveram início na pesquisa genética e envolveram toda a cadeia produtiva desde a alimentação de alto padrão técnico e nutricional e as etapas da linha de abate (Northcutt, 1997).

Apesar desses grandes avanços no Brasil não existe nenhum sistema oficial especialmente estabelecido para garantir ao consumidor a qualidade do produto de origem animal que está sendo comprado, embora muitas indústrias usem sistemas próprios. Nos EUA existe um sistema de classificação voluntário pago pela própria 
indústria o qual é diferente do sistema de fiscalização sanitária obrigatória. Através deste sistema, o produto considerado de qualidade superior, recebe uma estampa que garante uma certificação e utiliza-se como arma de comercialização, pois possui grande crédito entre os consumidores, ao mesmo tempo em que permite à indústria avaliar os seus processos de produção de maneira a proceder a mudanças positivas (Vieira, 1999).

A utilização de um sistema de classificação seria um excelente arma de comercialização para a industria nacional e competição com outros mercados. Este sistema possibilitaria a padronização do produto, criando um impacto positivo no mercado internacional e demonstrando a organização da industria brasileira na preocupação com a qualidade de seus produtos, trazendo com isso benefícios para o brasileiro (Vieira, 1999).

Para que o mercado seja expandido, a carne deve satisfazer os atributos de qualidade como textura, palatabilidade e aparência, harmonizando as necessidades de consumo como sustento básico e também satisfazer os requerimentos nutricionais (Valle, 2003).

Sabemos que a carne é essencial no suprimento dos nutrientes necessários para a manutenção da vida; com isso, seu consumo deve ser estimulado. A carne de frango é um dos alimentos de maior nível nutritivo para o consumo humano, não apenas como fonte de proteína de alta qualidade (22,8\%), minerais e vitaminas do complexo B (SEU $\beta, 1991$ ). Além de suas propriedades a carne de frango tem maior competitividade quanto ao preço de venda, sendo menor em relação às carnes de bovino e suíno.

Nos últimos anos, criou-se uma falsa idéia de que o consumo de produtos de origem animal, estaria associado à ocorrência de doenças cardiovasculares. Já as carnes de peito de aves têm baixo teor de gordura devido à reduzida necessidade de estocar energia nestes músculos; na cavidade abdominal e nas sobrecoxas é mais acentuado, caracterizando regiões onde reserva de energia é importante para o isolamento térmico e também para facilitar atividades físicas de longa duração (Langslow \& Lewis, 1974). Essas porcentagens diminuem, se retirar a pele de 11\% para 1,6\% (Barbut, 2002).

A pesquisa teve como objetivos na primeira fase aplicar uma forma de classificação de carcaças e cortes de frangos de criação alternativa mediante a avaliação 
de qualidade da carcaça ou carne baseados em atributos visuais (cor, conformação, presença de hemorragias e/ou machucaduras, rompimento de pele, ossos quebrados e falta de partes) e capacidade de retenção de água (CRA); na segunda fase avaliar os atributos de qualidade mediante análises físico químico e sensorial nos cortes de peito, coxa e sobrecoxa do frango alternativo às 5, 24, 48 e 72 horas após abate e estudar a correlação dos atributos de qualidade, tanto sensoriais como instrumentais do peito, coxa e sobrecoxa do frango alternativo às 5, 24, 48 e 72 horas após abate. 


\section{REVISÃO DE LITERATURA}

\subsection{A avicultura brasileira no mundo}

As mudanças no mercado de frango durante os passados trinta anos têm transformado o Brasil em um importante produtor e fornecedor de produtos industrializados de frango. Os presentes valores preliminares para 2003 mostram o Brasil como o terceiro grande produtor (7 843 mil toneladas/ano), e segundo exportador (1 922 mil toneladas/ano) de carne e produtos de frango, sendo que para o ano de 2004 a previsão é de uma produção de 8235 mil toneladas/ano e exportação de 2115 mil toneladas/ano (ABEF, 2004).

Portanto para continuar sendo uns dos primeiros no mercado internacional, a industria deve adaptar-se aos novos e maiores padrões de qualidade, isto é, atingir estes padrões e manter a posição competitiva no mercado.

\subsection{A avicultura brasileira}

Os sistemas de produção de frango de corte encontrados no Brasil podem ser resumidos da seguinte forma:

\subsubsection{Sistema industrial ou convencional}

É o sistema utilizado em granjas de exploração comercial, de linhagens comerciais geneticamente selecionadas pela alta taxa de crescimento e excelente eficiência alimentar, criados em sistemas intensivos segundo as normas sanitárias vigentes, sem 
restrições ao uso de antibióticos, anticoccidianos, promotores de crescimento, quimioterápicos e ingredientes de origem animal.

\subsubsection{Sistema caipira ou colonial}

Sistema de produção de aves de corte coloniais/caipiras normalizados pelo ofício circular DOI/DIPOA Nº 007/99, de 19/05/1999, pelo Ministério da Agricultura, Pecuária e Abastecimento, onde as aves de corte são denominadas de frango caipira, frango colonial, frango tipo caipira, frango estilo caipira, frango tipo colonial, frango estilo colonial. Apenas linhagens específicas de crescimento lento são permitidas. As aves devem ter acesso a área externa e não pode receber produtos quimioterápicos e ingredientes de origem animal na ração. A idade mínima de abate é de 85 dias.

\subsubsection{Sistema alternativo}

Sistema de produção de aves de corte de exploração intensiva ou não, sem restrição de linhagens, criados sem o uso de antibióticos, anticoccidianos, promotores de crescimento, quimioterápicos e ingredientes de origem animal na dieta. A proibição ao uso dessas substâncias é total; se houver necessidade de uso para fins terapêuticos o lote será comercializado como convencional, implicando em perda da qualidade própria do frango alternativo. Além de uma série de outros requisitos e normas aprovados e fiscalizados no âmbito da Associação da Avicultura Alternativa-AVAL (Demattê Filho \& Mendes, 2001).

\subsubsection{Sistema orgânico ou agro-ecológico}

Sistema de produção de aves de corte normalizado pela Instrução Normativa $N^{o}$ 007/99, de 19/05/1999 pelo Ministério da Agricultura, Pecuária e Abastecimento, onde se faz referência aos produtos obtidos pelo sistema orgânico, ecológico, biológico, biodinâmico, natural, sustentável, regenerativo e agro-ecológico. As aves são criadas em 
área de pastagem, com baixa densidade, com alimentação contendo ingredientes vegetais orgânicos certificados e produtos quimioterápicos não devem ser usados na criação.

O Brasil produz o frango mais barato do mundo com excelente padrão de qualidade, tendo grandes empresas exportadoras que são capazes de gerar as tecnologias necessárias. Outras empresas de pequeno e médio porte dependem de resultados obtidos em universidades e institutos de pesquisa para dar valor a seus produtos e melhorar a produtividade (Mendes, 2001).

A utilização de promotor de crescimento, de antibióticos ou outros antimicrobianos na avicultura que colocados na ração, têm como objetivo diminuir a flora bacteriana indesejável que existe no aparelho gastrointestinal. Com isso, melhora o aproveitamento do alimento ingerido e a saúde das aves (Mendes, 2001).

As ameaças à segurança alimentar levaram os consumidores a dar maior atenção aos alimentos orgânicos e saudáveis, o que aumentou a demanda por esse tipo de alimento, sendo considerada como a característica mais importante na seleção de alimentos orgânicos. As principais razões em que as pessoas não compram alimentos orgânicos, está na pouca disponibilidade no mercado, alto preço, e também porque foram considerados "não melhores que os produtos convencionais" (Jolly et al., 1989).

No Brasil vem crescendo a tendência de consumir produtos mais naturais, inclusive os alimentos produzidos em sistemas orgânicos que preservam o meio ambiente, sem uso de agrotóxicos e adubos químicos. O termo "consumo consciente" torna-se cada vez mais comum e evoca um consumidor que compra produtos que julga serem produzidos sob condições que preservam o meio ambiente e que promovem o bem-estar dos indivíduos e da sociedade (Demattê Filho \& Mendes, 2001 e Sundrum, 2001).

Castellini et al. (2002) avaliaram o efeito do sistema de produção orgânica na carcaça e qualidade da carne de frangos, em relação ao sistema de criação convencional. As aves criadas em sistema orgânico apresentaram rendimentos de peito e coxa mais elevados e níveis menores de gordura abdominal. Os músculos do peito e coxa 
mostraram resultados menores de $\mathrm{pH}$ final (24 horas) e capacidade de retenção de água, enquanto os valores de perda de peso por cocção, luminosidade, força de cisalhamento, Fe, ácidos graxos poliinsaturados n-3 e TBA-RS (substâncias reativas ao ácido tiobarbitúrico) foram maiores. A qualidade sensorial do peito foi considerada melhor. Os atributos de qualidade da carcaça e da carne de frango orgânico encontrado na pesquisa foram bons, com exceção do valor mais elevado de TBA-RS nos músculos, que indica a extensão da oxidação dos lipídeos, provavelmente devido à maior atividade física das aves.

\subsection{Classificação de carcaças e cortes de frango}

Com relação à indústria de carcaças de aves, a grande prioridade é o desenvolvimento de um sistema de classificação automático de carcaça, baseado na avaliação físico e química ou estética da carne de aves, garantindo ao consumidor a melhor qualidade do produto. $\mathrm{O}$ objetivo do sistema de classificação é pagar de acordo à qualidade da carcaça valorizando o preço de carcaça e provendo informações sobre a qualidade do sistema de produção. Através da classificação da carcaça e de acordo com o sistema tradicional de classificação, ou seja, peso, conformação, presença de hemorragias e/ou machucados, rompimento de pele, ossos quebrados e falta de partes, torna-se possível obter informação sobre qualidade de manejo de pré-abate e abate (Estados Unidos, 1999).

Com o aumento da produção de carne de frango, e o interesse das cadeias de mercado de alimentos para produção de um produto padrão e obter produtos com medidas objetivas da carne de ave de alguns parâmetros físicos como cor e maciez (Abeni \& Bergoglio, 2001).

A qualidade é referida às propriedades inerentes do produto que determina seu grau relativo de excelência ou valor. Pesquisas têm identificado algumas propriedades que são decisivas para o produtor, para o processador e para o consumidor. Algumas delas estão relacionadas com uma boa proporção de carne no osso/esqueleto, adequada 
cobertura de pele, ausência de penas, e livre ou ausência de descolorações (Estados Unidos, 1999).

O padrão de qualidade enumera os fatores de qualidade que afetam estas propriedades e é aplicada para carcaças e cortes prontos para consumo e produtos. Não se tem padrão para miúdos, descartes de pescoço e pigostílio, pontas de asas e pele. Segundo recomendações dos Estados Unidos (1999), para carcaças e partes os fatores de qualidade incluem: conformação, carne, cobertura de gordura, depenagem, carne exposta, descolorações, ossos deslocados e ossos quebrados, ausência de partes da carcaça e defeitos por congelamento (se fora aplicado). Para produtos como peito sem osso e pele os fatores incluem: presença de osso, tendões, cartilagem, descolorações e coágulo de sangue, assim como fatores próprios do produto.

A classificação envolve a avaliação das aves em termos de padrões para determinada categoria ou qualidade. O padrão de qualidade tem mudado nos últimos anos refletindo no desenvolvimento da produção, processamento e mercado de aves. Os Estados Unidos (1999), avaliam as carcaças e partes determinando a qualidade mediante a conformação, conteúdo de carne e cobertura de gordura como fatores principais. Isto faz mais fácil decidir sobre outros fatores. A intensidade, área, localização e número de defeitos devem também ser avaliados. Em cada nível de qualidade há um máximo de defeitos permitidos, alguns variam com o peso para carcaças prontas para consumo. A classificação é aplicada na maioria dos produtos da mesma classe e linhagem, conforme aos requerimentos do padrão. A estimação da qualidade final das carcaças das aves é baseada nos fatores com menor valor. Então, se os requisitos para a qualidade A apresenta o menor numero de defeitos, enquanto que as presenças de maiores defeitos são rebaixadas para as categorias B ou C (Estados Unidos, 2002).

Quando o avaliador classifica a carcaça ou partes, os procedimentos do nível de qualidade aceitável (NQA) usados estão baseados na porcentagem de defeitos subclassificando as carcaças ou partes que apresentam maiores defeitos. Se o resultado do NQA mostra que há excessivos defeitos, o produto é recusado ou retirado para um nível de qualidade inferior. Os defeitos excessivos encontrados na classificação e o manejo da planta ajudam na identificação e correção do problema (Estados Unidos, 1999, 2002). 
Os Estados Unidos (1999, 2002), indicam como fatores de qualidade para carcaças e cortes as seguintes características que deveram de considerar-se:

(1) Conformação, a estrutura ou forma da ave a qual pode afetar a distribuição e quantidade de carne, enquanto que muitos defeitos diminuiriam sua aparência. Alguns dos defeitos observados são peitos e dorsos dentados, curvos ou arqueados, pernas e asas deformes e corpo em forma de cunha ou cuneiforme.

(2) Conteúdo de carne, a coxa, sobrecoxa e peito devem ter grande quantidade de carne, e manter correlação entre a coberta de carne sobre o dorso e a quantidade de carne sobre o resto da carcaça. As fêmeas quase invariavelmente têm maior quantidade de carne no dorso e geralmente tem uma aparência arredonda no peito e pernas. O defeito comum no peito é a forma de $\mathrm{V}$ ou côncava, as pernas são finas e dorso apresenta insuficiente conteúdo de carne para cobrir a vértebra e o osso do quadril.

(3) Cobertura de gordura em aves é julgada principalmente pela acumulação de gordura baixo a pele, sendo constante para partes ou cortes; as acumulações ocorrem primeiro ao redor dos folículos das penas, na união do ossinho da sorte e onde a pele junta-se com a sobrecoxa e peito e nos folículos das penas ao final do dorso e quadril.

(4) Penas, o processamento tenta eliminar o problema de penas no abate após a depenagem, os equipamentos utilizam dedos de borracha, pinças e escovas para facilitar a remoção das penas. A carcaça pode ser considerada livre de penas, se geralmente tem aparência limpa (especialmente no peito e pernas) e se não tem mais que algumas ocasionais penas evidenciadas durante uma cuidadosa avaliação da carcaça.

(5) Carne exposta, cortes, dilaceramento e ossos quebrados diminui a aparência da carcaça e partes permitindo que a carne se desidrate durante o cozimento, diminuindo a qualidade que será observada pelo consumidor. O tamanho dos cortes de pele depende de sua localização.

(6) Descolorações da pele, manchas de carne e contusões, são consideradas como leve, de cor rosa e geralmente não são detectadas na avaliação da aparência do produto; ligeira ou leve tonalidade, de cor avermelhada encontrada na pele ou superfície da carne; e moderada, de cor vermelha escura ou azulado ou áreas de contusão na carne. A contusão só é permitida quando não há coagulação de células de sangue. Pequenos 
coágulos na pele ou na superfície podem ser retirados no processo de resfriamento, e logo serão considerados na avaliação da qualidade. As contusões azul escura e verde são retiradas antes da classificação. A intensidade amarela não é um fator de qualidade, a cor ocorre geneticamente quando o pigmento carotenóide é depositado na camada epidérmica da pele; sendo intensificado pela incorporação de pigmentos conhecidos como xantófilos na dieta das aves. Se as aves são escaldadas a temperaturas entre 51 a $52{ }^{\circ} \mathrm{C}$, a camada epidérmica (cutícula) da pele permanece dando uma aparência amarela acentuada; para produtos prontos são utilizadas temperaturas elevadas entre 55,6 a 57,8 ${ }^{\circ} \mathrm{C}$ para remover a cutícula e obter uma aparência brilhante na carcaça da ave.

As manchas de sangue estão relacionadas com o ferimento de músculos, quando tem uma contusão ou teve uma descoloração e/ou quebra de osso, ocorre uma ruptura dos vasos sangüíneos. O ferimento pode ser produzido nas diferentes etapas de vida da ave, durante o período de crescimento. Geralmente uma contusão vermelha indica que é recente, e uma maior descoloração enegrecidas e azuladas na superfície é indicação de contusão antiga (Barbut, 2002).

Embora a descoloração rósea seja um problema estético, este pode afetar grandemente a conduta de compra do consumidor. Os consumidores podem interpretar as descolorações róseas como um indicador de produtos com cozimento insuficiente e que não são seguros para consumo. Como conseqüência este defeito pode resultar em perdas econômicas serias para o varejista, processador e produtor de produtos de aves (Holownia et al., 2003).

A capacidade de retenção de água (CRA) é a capacidade ou habilidade da carne de segurar ou ligar a água. Um critério importante para a determinação da qualidade da carne é capacidade de retenção de água (CRA), que é a capacidade do músculo e dos produtos cárneos de manter a água ligada sob condições específicas. Sua importância está no fato de que essa característica este relacionada com o aspecto da carne antes do cozimento, comportamento durante a cocção e palatabilidade do produto. A CRA é medida através da perda de peso por cozimento, normalmente a carne da coxa e sobrecoxa perde mais peso após o cozimento. Deve-se provavelmente a maior 
quantidade de gordura e também porque existe, proporcionalmente, menos proteína funcional disponível para absorver água. As condições de criação do frango tais como: temperatura, estresse pelo calor e alta densidade podem afetar a CRA (Mendes, 2001, Barbut, 2002).

Segundo Barbut (2002, 1998), o sistema de classificação é baseado principalmente em fatores estéticos (descolorações, falta de parte, contusões), mas poderiam ser utilizados outros parâmetros como: a capacidade de retenção de água, textura. Utilizando-se o critério estético para a classificação das carcaças e cortes, é atrativo para o consumidor de carne fresca, porém, são de pouca utilidade para o processador quem demanda carne com alta CRA e boa textura. Enquanto que o CRA é importante na água adicionada aos produtos como peitos de peru assados no forno, a textura também é importante nas fatias de carne assada. Porém, pelas exigências do mercado, as carcaças e cortes selecionados para o processamento tiveram um aumento nos problemas de qualidade da carne, associado com dureza e pobre coesividade, cor e capacidade de retenção de água (Sosnicki \& Wilson, 1991).

Para o consumidor a aparência é o principal critério para a seleção e avaliação da qualidade da carne. Outros atributos como maciez, suculência, perda de gotejamento, perda de peso por cozimento, vida útil são importantes após a compra do produto, porém, também características essenciais no processo, no qual se adiciona valor ao produto cárneo (Allen et al., 1998; Qiao et al., 2002).

\subsection{Atributos de qualidade da carne de frango}

O termo qualidade da carne pressupõe um conceito bastante amplo, complexo e ambíguo. Envolve diversos aspectos interrelacionados, que englobam todas as etapas da cadeia agro-industrial, desde o nascimento do animal até o preparo para o consumo da carne in natura e de produtos cárneos processados. Fatores como idade, sexo, nutrição, apanha dos animais, transporte, temperatura ambiente e tempo de jejum, reconhecidamente afetam a composição da carne e são fatores que influenciam a cor, 
textura e sabor (Kauffman \& Marsh, 1987 e Lyon et al., 2004). Entretanto, a alteração da qualidade também pode ser obtida através da utilização de diferentes tecnologias de abate e pós-abate, como tempo de resfriamento, tempo e temperatura de maturação e estimulação elétrica (Northcutt, 1997). O conceito em si varia conforme a região geográfica, as classes sócio-econômicas, as diferentes visões técnico-científicas, industriais, comerciais e questões culturais, entre outros aspectos. Varia também de acordo com as características próprias de cada consumidor e com suas preferências individuais (Contreras \& Custodio, 2002).

A qualidade de carne de frango é dependente da temperatura do tecido muscular e da velocidade de resfriamento pós abate, sendo que as velocidades das reações bioquímicas são reduzidas em baixas temperaturas, e o resfriamento rápido imediatamente pós abate levam à redução na velocidade dos processos de tenderização (Vieira, 1999).

Após a fase de abate as carcaças e cortes das aves são transportadas e entregues aos varejistas (supermercados, açougue e outros), onde o consumidor terá que avaliar a qualidade do produto para sua compra. Como o consumidor é o ponto final da cadeia alimentar, é ele que tem que ser convencido de que a carcaça ou corte de frango apresenta os atributos de qualidade por eles desejados.

Para a avaliação da qualidade da carne, são levados em consideração critérios objetivos, tais como $\mathrm{pH}$, capacidade de retenção de água, maciez, cor da pele e cor da carne. Para a avaliação das características organolépticas são realizados testes subjetivos, como a utilização de painel de provadores. Os principais atributos exigidos pelo consumidor são cor, aparência, textura e sabor.

\subsubsection{Aparência}

A carne de frango pode ser vendida com ou sem pele. O frango é a única espécie conhecida que tem músculos com cores extremas: a carne de peito tem uma cor rosa pálida enquanto que a carne da coxa e da sobrecoxa possuem coloração vermelha, 
quando crua. Algumas alterações de cor podem ser observadas em decorrência de algum problema na industrialização (Barbut, 2002, 1998).

Além das variáveis de processamento, a cor da carne de frango pode ser afetada por outros fatores como: idade, sexo, dieta, gordura intramuscular, conteúdo de umidade das carnes, linhagem, condições de pré-abate. A cor da carne depende da presença dos pigmentos heme muscular denominados mioglobina e hemoglobina. A presença de manchas na carne pode estar relacionada com a quantidade destes pigmentos presentes na carne, o estado químico desses pigmentos ou o modo como a luz é refletida. As variações na concentração da mioglobina dependem da atividade muscular e da demanda de oxigênio. Existe diferença entre os músculos do peito e coxa enquanto a necessidade de oxigênio (Barbut, 2002).

A coloração da carne de frango in natura é importante porque os consumidores associam a cor com produtos frescos e de boa qualidade, influenciando assim na decisão da compra (Allen et al., 1998).

A cor da pele também pode variar quando se tem o aumento de ingestão de xantofila na dieta, e a coloração da pele se torna mais amarelada. Uma temperatura de escaldagem elevada reduz a pigmentação da pele pela remoção parcial da cutícula. Caso essa remoção seja realizada em temperaturas de escaldagem não recomendadas, pode ocorrer o espalhamento do sangue sobre o músculo. O congelamento promove uma cor mais esbranquiçada à carcaça, bem como a linhagem da ave, pode influenciar na cor da pele das mesmas (Maurer, 2000).

As aves antes de serem abatidas são sujeitas a uma série de eventos nos últimos dias de suas vidas, são postas num jejum alimentar para reduzir a contaminação fecal, e logo apanhadas e colocadas em gaiolas e transportadas à planta de processamento. Reportes indicaram que as aves que chegam à planta de processamento com contusões entre 0,022 a $25 \%$ (Farsaie et al., 1983 e Ekstrand, 1998). As porcentagens são dificilmente interpretadas, porque poderiam ser influenciadas pela diferença entre os métodos de inspeção e padrões de qualidade utilizados para a avaliação das carcaças (Knowles \& Broom, 1990). Não obstante, atribui-se ao enorme numero de aves de corte que são abatidas geralmente, perdas financeiras devido à mortalidade e taxa enorme de 
injurias. Fatores como método de apanha, tempo de transporte, tempo de espera, tipo de caixas de transporte, período de apanha e transporte (dia ou noite), densidade por gaiola, idade e sexo, temperatura ambiente tem sido reportados como parâmetros que influenciam as contusões das aves (Scholtyssek \& Ehinger, 1976; Mayes, 1980; Farsaie et al., 1983; Bingham, 1986; Lacy \& Czarick, 1994 e Ekstrand, 1998).

Períodos de jejum alimentar acima de 24 horas afetam significativamente o conteúdo de gordura na carne (Ang \& Hamm, 1985 e Bartov, 1992), a quantidade relativa de gordura abdominal ou a composição de ácidos graxos na carne (Bartov, 1992).

Por outro lado, a sangria incompleta ou imprópria, pode produzir carcaças avermelhadas. Os vasos de sangue intumescidos e coração, fígado e baço congestionado sugerem uma sangria pobre. A recomendação para a produção de produtos de frangos livre de defeitos de cor envolve o controle sobre algumas variáveis, tais como, adoção de práticas cuidadosas de manejo, utilização de alimentos e água de boa qualidade, cuidados na apanha, engradado, pendura e processamento das aves, uso de atordoamento apropriado, escaldagem, e adequação da carcaça nos depenadores. A formulação de produtos de aves deve incluir ingredientes de alta qualidade, e seguir as boas práticas de manufatura. Os equipamentos utilizados no processamento devem estar limpos e funcionando adequadamente. Desta forma, as carnes e produtos seguramente terão características de cor desejável pelos consumidores, indicando a alta qualidade da cor dos produtos (Contreras \& Beraquet, 2001).

Com o rápido crescimento da industrialização da carne de aves têm-se observado vários problemas como a textura, coesividade e suculência, e a questão de PSE ganha importância. O PSE (pale, soft and exsudative) em aves, é causado em conseqüência da rápida glicólise, e resulta em carnes com alta perda de exsudado e características indesejáveis. Este fenômeno é prognosticado pela combinação de análises de pH e da cor no músculo do peito (Swatland, 1995). Polidori et al. (1999), reportaram a correlação entre $\mathrm{pH}$ após 24 horas post mortem, luminosidade e problemas PSE para carne de aves, confirmaram a importância da medição correta do parâmetro de cor. A perda da funcionalidade da proteína é devido à desnaturação extensiva da proteína é considerado 
o principal fator associado com o desenvolvimento das características PSE da carne (Warris \& Brown, 1987; Fernandez et al., 1994 e Santos et al., 1994).

Sandusky \& Heath (1998), observaram que a avaliação instrumental esta correlacionada com a estimação sensorial da cor de peito de aves. Sugerem a importância de harmonizar a avaliação instrumental em condições de operação da carne de corte, principalmente para grandes quantidades de amostras, onde o resultado da cor é muito importante como a utilização da luminosidade (L*) (Sandusky \& Heath, 1998).

A cor e aparência são importantes aspectos de qualidade (Van Laack et al., 2000 e Qiao et al., 2001). A refletância da luz tem sido utilizada para a medição da cor da carne, e a luminosidade $\left(\mathrm{L}^{*}\right)$ do file de frango é negativamente relacionada ao $\mathrm{pH}$ final e menor perda de umidade com a refrigeração e cozimento (Allen et al., 1998; Polidori et al., 2000; Qiao et al., 2001 e Woolfel et al., 2002). Alterações como conseqüência do congelamento e descongelamento tem recebido pequena atenção. $\mathrm{O}$ estresse pré-abate, sexo, idade e genética influenciam na cor da carne (Fletcher, 1999 e Berri et al., 2001).

Boulianne et al, (1995, 1998), examinaram as propriedades bioquímicas associadas com a ocorrência da cor pálida e escura em file de peito de corte e reportaram que o pigmento total, mioglobina e concentrações de ferro, foram significativamente diferentes comparadas com as carnes normais.

Defeitos na cor da carne ocorrem quando existem manchas vermelhas ou rosas, verdes, enegrecidas ou azuladas sobre o músculo das carcaças das aves dependem das condições durante a apanha, o engradado, o manuseio e a morte das aves. As aves vivas submetidas ao estresse pelo calor e excitação desenvolvem uma cor de músculo vermelha, rica em mioglobina. Segundo Kranen et al. (1999), o conteúdo de hemoglobina no músculo adutor de diferentes tipos de hemorragias mostrou um aumento de dez vezes no pigmento de hemoglobina presente.

As práticas tais como: apanha imprópria das pernas e coxas podem permitir um batimento excessivo das asas, como também um atordoamento incorreto antes do abate podendo romper os vasos de sangue e causar hematomas. A quantidade de hematomas elevados pode ocorrer quando as aves voam e sentem medo (Leandro et al., 2001). 
As aves também apresentam hematomas em dias de muito calor devido a maior quantidade de sangue na superfície ou quando há grandes variações de temperaturas. As juntas ensangüentadas de asas e coxas de frango ocorrem mais freqüentemente quando as noites são frias e os dias quentes (Mayes, 1980).

$\mathrm{O}$ atordoamento apropriado imobiliza as aves ajudando na sangria. A eficiência do processo envolve o controle de parâmetros como corrente, voltagem, freqüência, tipo de onda e tempo de imersão. Os defeitos na qualidade da carne de ave atribuídos ao uso de correntes de atordoamento que ocasionam ataque cardíaco são variados. Cinco efeitos adversos estão associados ao uso de voltagens elevadas: (1) hemorragias nas asas, (2) coloração roxa da pele, (3) depenagem difícil, (4) ossos quebrados, e (5) manchas de sangue ou coágulos no músculo do peito da ave (Gregory, 1989). Um atordoamento com corrente e voltagem elevados causam vasos intumescidos e ensangüentados os quais durante a depenagem, provavelmente, se arrebentarão, resultando na ocorrência de hematomas vermelhos.

A descoloração pode ocorrer no músculo inteiro ou numa parte limitada, como uma contusão ou uma rotura do vaso sangüíneo. Temperaturas ambientes extremas ou estresse devido à manipulação da ave viva antes do processamento, podem causar descoloração de carne de peito de frango e peru. A extensão da descoloração esta relacionada com as respostas individuais de cada ave a tais condições. Em 1994, aproximadamente $29 \%$ de todas as carcaças processadas nos EUA foram danificadas (redução da qualidade) e a maioria desses defeitos (28\%) foi decorrente de contusões (Vieira, 1999). A indústria de frango geralmente tenta identificar onde (granja ou planta), como e quando os danos ocorrem. A cor, a quantidade de sangue presente e a extensão da formação do coágulo de sangue na área afetada pela contusão são bons indicadores do tempo em que se ocasionou a injúria e pode dar alguns indícios de sua origem. As injurias que ocorrem na granja são freqüentemente realçadas pelo equipamento e manipulação na planta de processamento (Estados Unidos, 1999).

A quantidade de gordura presente na carne é uma característica de qualidade que vem ganhando cada vez mais importância devido à crescente conscientização da imagem corporal e para o fato de que dietas com alto teor de gordura levam ao aumento de 
problemas cardiovasculares. Carnes de peito de aves apresentam teor baixo de gordura devido à reduzida necessidade de estocar energia nestes músculos. Já os depósitos de gordura sub-cutânea, na cavidade abdominal e nas sobrecoxas são bastante acentuados, caracterizando regiões onde a reserva de energia é importante, seja para o isolamento térmico, seja para facilitar atividades físicas de longa duração. Os depósitos de gordura são ainda de maior proporção em fêmeas do que em machos (Langslow \& Lewis, 1974).

$\mathrm{O}$ frango de corte moderno é resultado da seleção para um rápido crescimento e dessa forma consume grandes quantidades de alimento. Como consequiência na ave é depositada muito rápido a gordura e em grandes quantidades. Entretanto, diferenças relacionadas à quantidade total de gordura na carcaça existem entre linhagens. Vieira \& Moran (1998) observaram diferenças de até $20 \%$ na quantidade de gordura abdominal entre diferentes linhagens comerciais.

\subsubsection{Textura (maciez)}

Avaliações sensoriais indicam que a maciez da carne é o atributo de palatabilidade mais freqüentemente percebido como um problema pelos consumidores. Deste modo, a importância da maciez e os fatores que a influenciam são enfatizados, assim como a consistência da textura da carne (Barbut, 2002). A textura é uma característica de qualidade da carne no cozimento (Bourne, 1982). Os métodos de processamento são diretamente afetados pelas características finais da carne.

As condições de criação do frango, tais como temperatura, estresse pelo calor e densidade de criação, podem afetar a CRA. Bressan (1998), observou que os peitos de aves mantidos em ambientes com temperatura de $30{ }^{\circ} \mathrm{C}$ apresentaram maior perda de peso por cozimento, com média de $28,7 \%$ quando comparadas com os peitos de aves que foram submetidos à ambientes de conforto térmico $\left(17^{\circ} \mathrm{C}\right)$, com média de $27,2 \%$.

Wood \& Richards (1975) e Ramussen \& Mast (1989), reportaram efeito significativo da duração do jejum alimentar sobre o valor de força de cisalhamento da carne mantidas por 24 horas post mortem. Lyon et al. (1991), observaram que o valor de força de cisalhamento da carne às 4 horas post mortem diminuiu com o aumento da 
duração do período de jejum alimentar. Altas temperaturas post mortem aceleram a glicólise e endurecem a carne de peito de corte, enquanto que temperaturas menores retardam a glicólise e o endurecimento da carne (Khan, 1971). O esforço violento antes do abate esgota o glicogênio do músculo e consequentemente uma menor acumulação de ácido láctico nos músculo durante a glicólise post mortem, resultando no menor pH final e conseqüentemente menor vida útil (Wood \& Richards, 1975).

O procedimento tradicional no abate de carcaças envolve o resfriamento "chilling" de carcaças em gelo e água de 45 minutos a 1 hora, e posteriormente são mantidas por 4 a 8 horas antes da desossa para a obtenção de uma maior maciez no file de peito (Lyon et al., 1985 e Dawson et al., 1987). Este tempo é necessário para o término das reações bioquímicas post mortem com influencia na maciez de peito de frango após o cozimento (Stewart et al., 1984).

O processo de desenvolvimento do rigor mortis é o fator que mais influencia na transformação do músculo em carne e na sua qualidade. O rigor mortis é um fenômeno que admite pouca modulação, porém ocorrem alterações se o animal estiver estressado momentos antes do abate, quando se acentua a redução nos níveis de fosfocreatina e ATP. A concentração de glicogênio diminui com o jejum ante-mortem seguido de exercícios e outros estresses fisiológicos. $\mathrm{Na}$ ausência de oxigênio a queda do pH é devida inicialmente à liberação de íons $\mathrm{H}^{+}$resultantes da hidrólise enzimática do ATP, quando em pH 7,0, partes destes íons são novamente ligadas durante a fosforilação de ADP em ATP. Depois, as maiorias dos íons formadas, por volta de $90 \%$ são resultado da degradação de glicogênio e glicose-6-fosfato em lactato. Para cada lactato formado ocorre a liberação de um íon hidrogênio (Honikel \& Ham, 1974). Uma medida indireta de determinação da maciez é o pH, que está relacionado com o rigor mortis (Smith et al., 1992b).

Qualquer fator que pode interferir na formação do rigor mortis ou no processo de amolecimento da carne que o segue, afetará a maciez da carne. Por exemplo, aves que lutam antes ou durante o abate apresentam um esgotamento de energia mais rápido em seus músculos antecipando o início do rigor mortis. A textura destes músculos tende a ser mais dura devido à energia que foi reduzida na ave viva. Um efeito similar ocorre 
quando as aves são expostas ao estresse ambiental, temperaturas quentes e frias antes do abate. O atordoamento não controlado, temperatura elevada, e longos períodos de escaldagem e corte dos músculos de frango pelas máquinas em condições de pré-rigor, também podem causar rigidez na carne de frango (Barbut, 2002 e Price \& Schwiegert, 1994).

A maciez da carne poderia ser controlada por fatores de manipulação que determinam a faixa de desenvolvimento do rigor no músculo. Freqüentemente, o rigor se desenvolve em aves de 0,5 a 6 horas após a morte, e a carne pode ser removida da estrutura do corpo ainda estando no processo de rigor, produzindo uma carne dura (Ma \& Addis, 1973).

A maciez de cortes desossados de frango é influenciada pelo tempo post mortem de desossa. Os músculos desossados durante o tempo inicial post mortem ainda possuem energia disponível para a contração. Quando esses músculos são removidos da carcaça, eles se contraem e ficam rígidos. Para evitar este endurecimento, a carne é usualmente maturada por 6 a 24 horas antes da desossa, mas esse procedimento torna o custo elevado (Sams, 2001).

Quando a carne é desossada cedo (0 a 2 horas post mortem), de 50 a $80 \%$ da carne se torna rígida. Por outro lado, se o processador esperar 6 horas antes da desossa, 70 a 80 \% da carne torna-se macia. A indústria de frango tem usado, recentemente, a estimulação elétrica imediatamente pós-abate para acelerar o desenvolvimento do rigor da carcaça e reduzir o tempo de maturação antes da desossa (Lyon et al., 1992).

Resultados sugerem que aumentando o período de maturação dos filés de peito que foram desossados pré-rigor diminui-se um pouco a rigidez da carne associada a desossa prematura (Stewart et al., 1984).

Durante a maturação da carne post mortem, origina-se um estado débil das miofibrilas, dos filamentos intermediários como a desmina, e tecido conectivo intramuscular; ocasionado pela ruptura dos filamentos titina e nebulina, diminuição da estrutura do disco $\mathrm{Z}$ e debilitamento da ligação formada entre actina e miosina no rigor mortis (Takahashi, 1996). 
Valores de força de cisalhamento indicados por McKee et al. (1997) sugerem que não há melhora na maciez devido ao aumento do tempo de maturação pós-desossa entre 0 e 23 horas. Estendendo-se a maturação às 71 horas após desossa resulta num valor de força de cisalhamento reduzida. No entanto, os filés com 71 horas de maturação após desossa, não produzem a força de cisalhamento ao nível dos filés controle desossados às 24 horas post mortem. Os resultados obtidos por Sams (1999), mostraram que os processadores de filés de peito que desossaram imediatamente após resfriamento (1 - 1,5 hora post mortem) poderiam obter uma carne com maciez aceitável se os cortes fossem adicionalmente maturados.

O corte ou desossa imediatamente após a evisceração resultam na dureza do músculo, a perda da maciez, CRA e perda por cozimento (Klose et al., 1971). A CRA depende da fase post mortem em que se encontra o músculo. Geralmente é elevada na fase de pre-rigor, e é reduzida no rigor mortis, voltando a se elevar novamente no post mortem. No músculo intacto a diminuição da CRA nas primeiras horas post mortem é determinada pela velocidade de queda do pH e não pela concentração de ATP (Judge et al., 1989)

Algumas das tecnologias incluindo a estimulação elétrica (Maki \& Froning, 1987 e Sams et al., 1989), marinação (Young \& Lyon, 1997) e uma combinação destes métodos (Sams, 1990 e Sams et al., 1991) têm obtido resultados positivos no melhoramento da maciez da carne desossada pre-rigor. Não obstante, no trabalho de estimulação elétrica de peito de frango encontraram inconsistência nos resultados devido aos diferentes tempos de aplicação da estimulação elétrica, técnicas de maturação, parâmetros elétricos como voltagem, frequiência e tipo de onda, procedimentos de análise da variabilidade de maciez, e variações biológicas e físico-químicas (Li et al., 1993). Portanto, nenhuma das tecnologias antes mencionadas garante a maciez da carne de corte.

$\mathrm{O}$ atordoamento elétrico de aves retarda o desenvolvimento do rigor. Para que isto ocorra torna-se necessário que a carne seja mantida na carcaça pelo menos 4 horas para apresentar uma textura aceitável. A estimulação elétrica previne a dureza da carne de aves quando desossados prematuramente. Contreras (1995) observou que com tempo de $30 \mathrm{~s}$ de estimulação elétrica de $45 \mathrm{~V}, 80 \mathrm{~V}$ e $100 \mathrm{~V}$ acarretou menor força de 
cisalhamento, tanto nas aves desossadas à quente como naquelas desossadas convencionalmente. Além disso, a estimulação elétrica ajudou a acelerar o processo de rigor mortis nas carcaças de frango desossadas a quente e desossadas convencionalmente, conseguindo reduzir o tempo de resolução do rigor mortis.

Estudos realizados por Contreras \& Beraquet (2001) confirmaram que o atordoamento elétrico com alta frequiência $(1000 \mathrm{~Hz})$, reduz o encolhimento do músculo melhorando a maciez do mesmo medido às 24 horas post mortem. Esse efeito da insensibilização na maciez da carne de aves não é claro. Existem vários autores como Lee et al. (1979) e Thompson et al. (1986) que também mostraram efeito significativo da insensibilização sobre medidas de maciez expressos em força de cisalhamento.

O colágeno é o maior componente do tecido conectivo intramuscular (Bendall, 1973 e Light et al., 1985) e tem importância na determinação da dureza da carne (Sims \& Bailey, 1981). Liu et al. (1996) mostrou que há correlação significativa entre o conteúdo de colágeno e o valor de força de cisalhamento do músculo esquelético de frango. $\mathrm{O}$ resultado sugere que o conteúdo de colágeno é um fator determinante na dureza da carne.

Outra estratégia para reduzir a dureza da carne desossada no estado pré-rigor é o uso da marinação. Neste processo a adição de uma solução contendo fosfatos e sais, além de cloreto de cálcio e enzimas ajuda no aumento da suculência e diminui a dureza na carne. A solução adiciona umidade, enquanto os fosfatos e o sal retém água no músculo. A marinação promove uma melhora na aparência física e na qualidade da carne, a qual é percebida pelo consumidor e aumenta os rendimentos do fabricante. Ambos atributos da carne são aperfeiçoados basicamente da mesma forma, ou seja, com a ligação química da água com o tecido muscular. Isto pode ser com a água que já se encontrava na carne ou a que foi adicionada posteriormente. Uma alta CRA equivale à maior suculência, maior palatabilidade e percepção sensorial melhorando também a qualidade da carne. Outros benefícios que podem ser incluídos são o enriquecimento do sabor pela adição de temperos (condimentos), e a redução na rancidez que se desenvolve durante a estocagem (Smith \& Acton, 2001). 
Em suma, diversos métodos de cozimento são possíveis para se produzir diversos produtos de frango prontos para consumo, e um grande número de diferentes métodos são necessários para suprir a variedade de produtos cozidos que são procurados pelos consumidores. A cocção geralmente melhora a qualidade do produto, mas há preocupação com a perda de vitaminas. O uso da marinação de alguma forma aliviou um pouco a preocupação com os problemas acima citados, mas as pesquisas contínuas dos métodos de cocção talvez promovam uma solução parcial para tais problemas.

\subsubsection{Sabor e aroma}

O sabor é um dos atributos decisivos na aceitação. A impressão deixada pelo sabor reúne tanto a percepção dos estímulos químicos recebidos pelo olfato e paladar, como dos estímulos físicos recebidos pela visão, audição e tato. A sensação do odor é muito mais complexa e está baseada na composição de dezenas de compostos voláteis, representantes de várias classes químicas com diferentes naturezas, como, por exemplo, físico e química (Farmer, 1999, Barbut, 2002).

Gosto e odor contribuem para o sabor da carne, e é geralmente difícil de distinguílos durante o consumo. Quando a carne de ave é cozida, o sabor e o odor desenvolvem interações de açúcares e de aminoácidos, oxidação lipídica e degradação da tiamina. Sabor e odor de carne de aves variam amplamente, com cada espécie animal tendo suas próprias características. Inversamente, diferenças entre o sabor das carnes de espécies animais têm sido relatadas como originárias da fração lipídica e estão associadas com diferentes componentes lipídicos (Hornstein et al., 1963). Portanto, as diferenças mais reconhecidas no sabor da carne de aves são resultado, acredita-se, das diferenças dos componentes lipídicos.

Sabores de carnes oxidadas e requentadas são grande interesse, pela comercialização de refeições pré-cozidas congeladas, onde ambos contribuem para o desenvolvimento de sabor estranho em produtos cárneos. O desenvolvimento é grandemente atribuído a autoxidação de ácidos graxos poliinsaturados, principalmente nos fosfolipídios e ferro, nas diferentes formas é um importante catalisador nas reações 
(Gray \& Pearson, 1987). A susceptibilidade e taxa de oxidação de fosfolipídios é dependente do nível de ácidos graxos presentes e de seu grado de insaturação. Autores como Tichivangana \& Morrisey (1985) e Rhee et al. (1996), têm demostrado que a oxidação lipídica dos músculos de alimentos ocorre na ordem de peixe > aves (frango e peru) > suínos > bovinos > ovinos. A ordem está relacionada com o aumento do nível de maior susceptibilidade de ácidos graxos insaturados em cada um destes tecidos fosfolipídicos e ao nível natural de antioxidantes presentes (Melton, 1983). O produto secundário de oxidação lipídica tem sido determinado como causa na detecção sensorial de sabores e aromas estranhos em carnes pré-cozidas e congeladas (St Tangelo et al., 1987). As mudanças oxidativas envolvem proteínas e componentes menores, como a formação de voláteis resultado das reações de Maillard, os quais são também envolvidos na perda do sabor da carne com desenvolvimento de sabores estranhos (Byrne et al., 2001 e Spanier et al., 1988).

Farmer (1999), sugere que proteínas, peptídeos, aminoácidos e nucleotídeos são os maiores componentes; a maioria encontra-se presentes na concentração inicial e que os efeitos sinergéticos são importantes na percepção do sabor. Sabores de oxidados e requentados também são de grande interesse, pelo aumento na comercialização de refeições pré-cozidas congeladas, onde ambos (congelamento e pré-cozimento) contribuem para o desenvolvimento de sabor estranho em produtos cárneos. No cozimento a mudança na concentração de açúcares redutores, aminoácidos livres e nucleotídeos afeta o sabor e aroma da carne da ave porque alguma das substancia são precursores de reações químicas responsáveis pela formação do odor durante o cozimento, assado ou fritura (Fujimura et al., 1996), diferindo de acordo ao tipo de cozimento (Farmer, 1999).

O sabor e aroma global no frango são influenciados pela concentração dos diferentes aminoácidos, açúcares, lipídios, temperatura, $\mathrm{pH}$ e outros. A temperatura de cozimento afeta a reação de Maillard e a oxidação de ácidos graxos. Tem-se demonstrado que as quantidades de voláteis produzem aumentos quando a temperatura de cozimento foi aumentada de 60 a $80^{\circ} \mathrm{C}$ (Ang \& Lui, 1996). Maiores temperaturas 
podem aumentar a porcentagem de reações químicas e liberar os aminoácidos livres e outros precursores.

Alguns outros componentes influenciam no sabor de aves como a gordura solúvel, e pode ser mais abundante na carne de coxa que da carne de peito (Lindsay, 1985). A presencia de gordura também contribui à característica de suculência no músculo (Williams \& Damrom, 1998b).

A suculência é a umidade durante as primeiras mordidas produzidas pela rápida liberação de fluídos. Devido à liberação lenta do suco da carne e ao potencial efeito estimulador da gordura na produção da saliva, e varia de acordo com as perdas por cozimento (Price \& Schwiegert, 1994).

O sabor é devido à presença e concentração de vários compostos solúveis em água, assim como o composto volátil do aroma. A concentrações de compostos e interações podem ser afetadas por diversos fatores como tempo ou tipo de estocagem, genética, sexo, idade, dieta, e fatores de processamento, método de cozimento (Farmer, 1999). Varmam \& Sutherland (1998), indicaram que a suculência está relacionada com a CRA e marmorização, além de existir interação com a aparência. Contrariamente uma carne se torna indesejável, quando apresenta gotejamento e exsudação excessiva (PSE), indicando defeitos de qualidade. A suculência junto com a maciez influenciam a qualidade sensorial global da carne. 


\section{MATERIAL E MÉTODOS}

Para o desenvolvimento deste trabalho foram utilizados frangos do tipo de linhagem comercial Cobb, com idade entre 48 e 49 dias, peso aproximado de $2-2,3 \mathrm{~kg}$. A forma de alimentação correspondeu ao frango de sistema alternativo que atualmente vem sendo comercializado no mercado brasileiro. A densidade das aves foi de 13 aves $/ \mathrm{m}^{2}$.

De acordo com pesquisa anterior (Pinto et al., 2004), os frangos, após o jejum alimentar de seis horas, nas granjas integradas da Empresa Korin Agropecuária Ltda, foram transportados em caixas plásticas até o abatedouro com um tempo médio de uma hora. As aves foram penduradas em ganchos e insensibilizados com atordoamento elétrico: na primeira etapa de classificação das aves utilizou-se $1140 \mathrm{~Hz}$ e $50 \mathrm{~V}$ e para a etapa de avaliação de atributos foi de $60 \mathrm{~Hz}$ e $50 \mathrm{~V}$ (segundo as condições do abatedouro), após a etapa de sangria de 180 segundos pelo corte da artéria carótida e veia jugular, os frangos foram escaldados a temperatura entre de $59-60{ }^{\circ} \mathrm{C}$ para a depenagem, depois de evisceradas forma resfriadas no pré-chiller $\left(14-16{ }^{\circ} \mathrm{C}\right.$ por aproximadamente 10 minutos) e chiller $\left(4-6{ }^{\circ} \mathrm{C}\right.$ por aproximadamente 15 minutos).

\subsection{Classificação das carcaças e cortes}

Para classificação das carcaças e cortes foram realizadas duas repetições, sendo tomadas aleatoriamente um total de 301 carcaças de frango na linha após a depenagem (Figura 1); 146 peitos, 147 coxas e 145 sobrecoxas na área de cortes (Figura 2). As carcaças e cortes de peito, coxa e sobrecoxa foram avaliados na sua aparência, e logo classificados em classe $\mathrm{A}, \mathrm{B}$ ou $\mathrm{C}$ de acordo com o número de defeitos apresentados, 
segundo o descrito pelos Estados Unidos (1999, 2002). Utilizou-se de um utilizado um gabarito com medidas estabelecidas para medição dos defeitos (contusões, rompimento da pele e outros), como mostra-se na Figura 3 e 4. Assim, nos corte de peito e coxa foram realizadas à análise de capacidade de retenção de água (CRA).

\subsubsection{Conformação}

Foi observada a estrutura ou forma do peito, dorso e perna da carcaça de frango, e como esta conformação afetou a distribuição e a quantidade de carne. Também foram observados os defeitos que podem depreciar a aparência como peitos dentados, curvos; dorso curvo ou arqueado; pernas e asas deformes. De acordo com o grau de defeitos as carcaças foram classificadas em A, B ou C, sendo que a classe A corresponde a categoria de qualidade superior (com menor ocorrência de defeitos), decrescendo até atingir a classe $\mathrm{C}$ (Quadro 1 e 2).

\subsubsection{Conteúdo de carne}

As carcaças e os cortes de peito, coxa e sobrecoxa, foram avaliados quanto à cobertura de carne no peito, coxa, sobrecoxa e asa e à aparência magra, de acordo com o tipo e classe, segundo Quadro 1 e 2.

\subsubsection{Depósito e cobertura de gordura}

Verificou-se a presença dos depósitos de gordura subcutânea na cavidade abdominal, peito e pernas, assim como a gordura acumulada sobre a pele e nos folículos das penas (Quadro 1 e 2). 


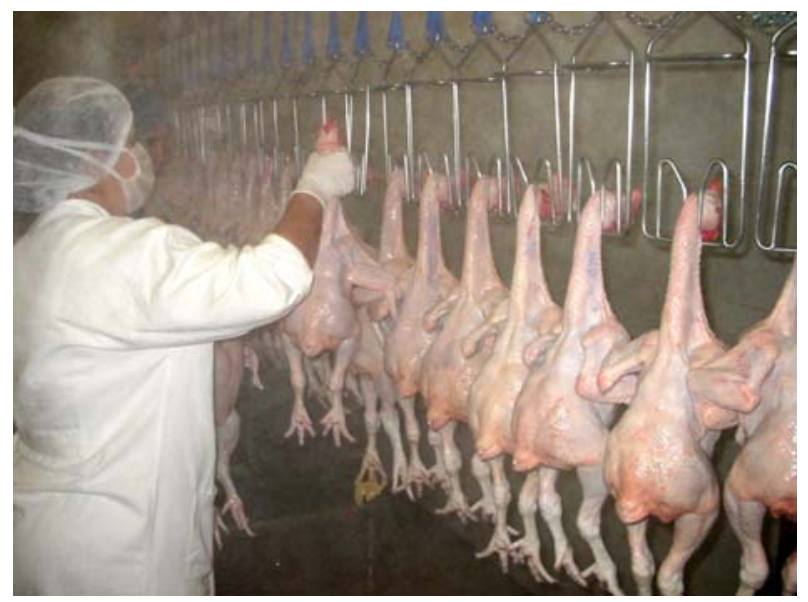

Figura 1 - Amostragem das carcaças na linha após a depenagem

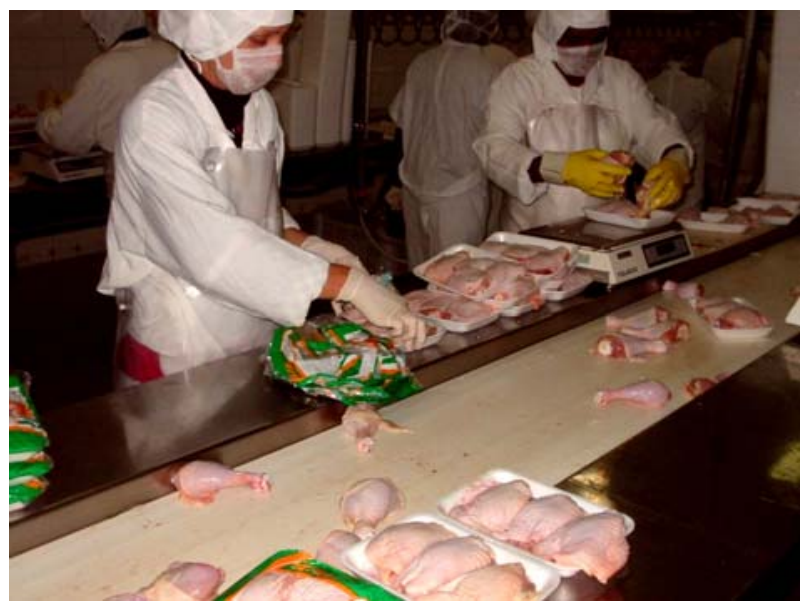

Figura 2 - Amostragem dos cortes na área de cortes

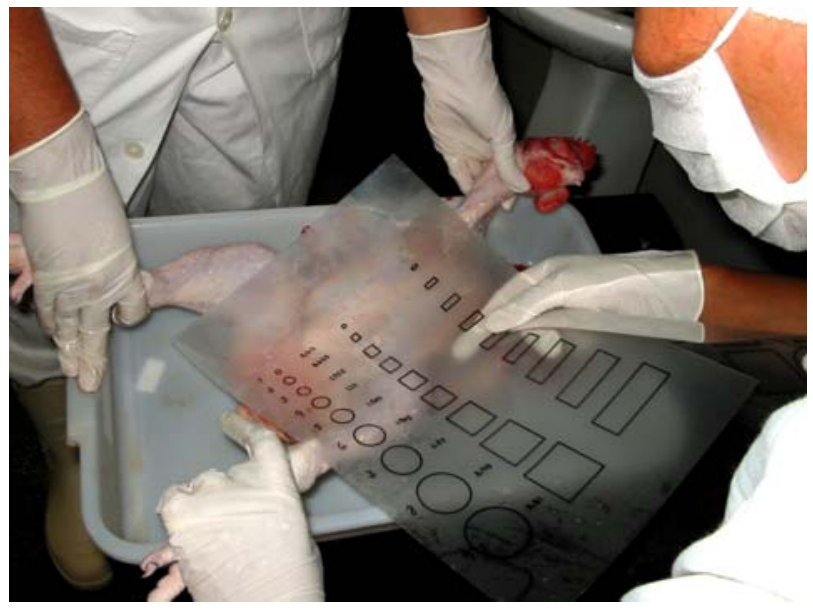

Figura 3 - Medição dos defeitos com o gabarito 


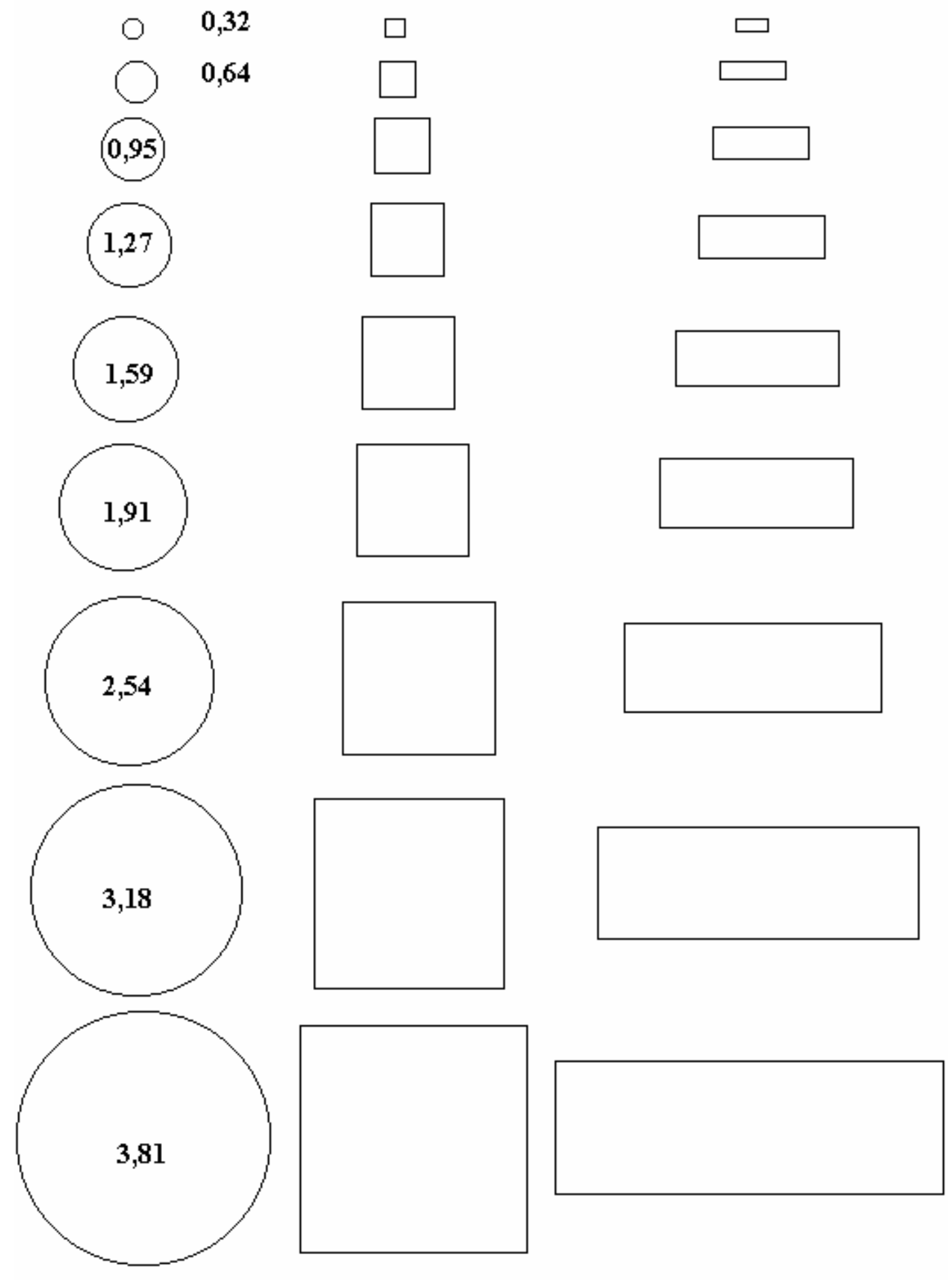

Figura 4 - Gabarito de medições (cm)

Fonte: Estados Unidos (1999) 


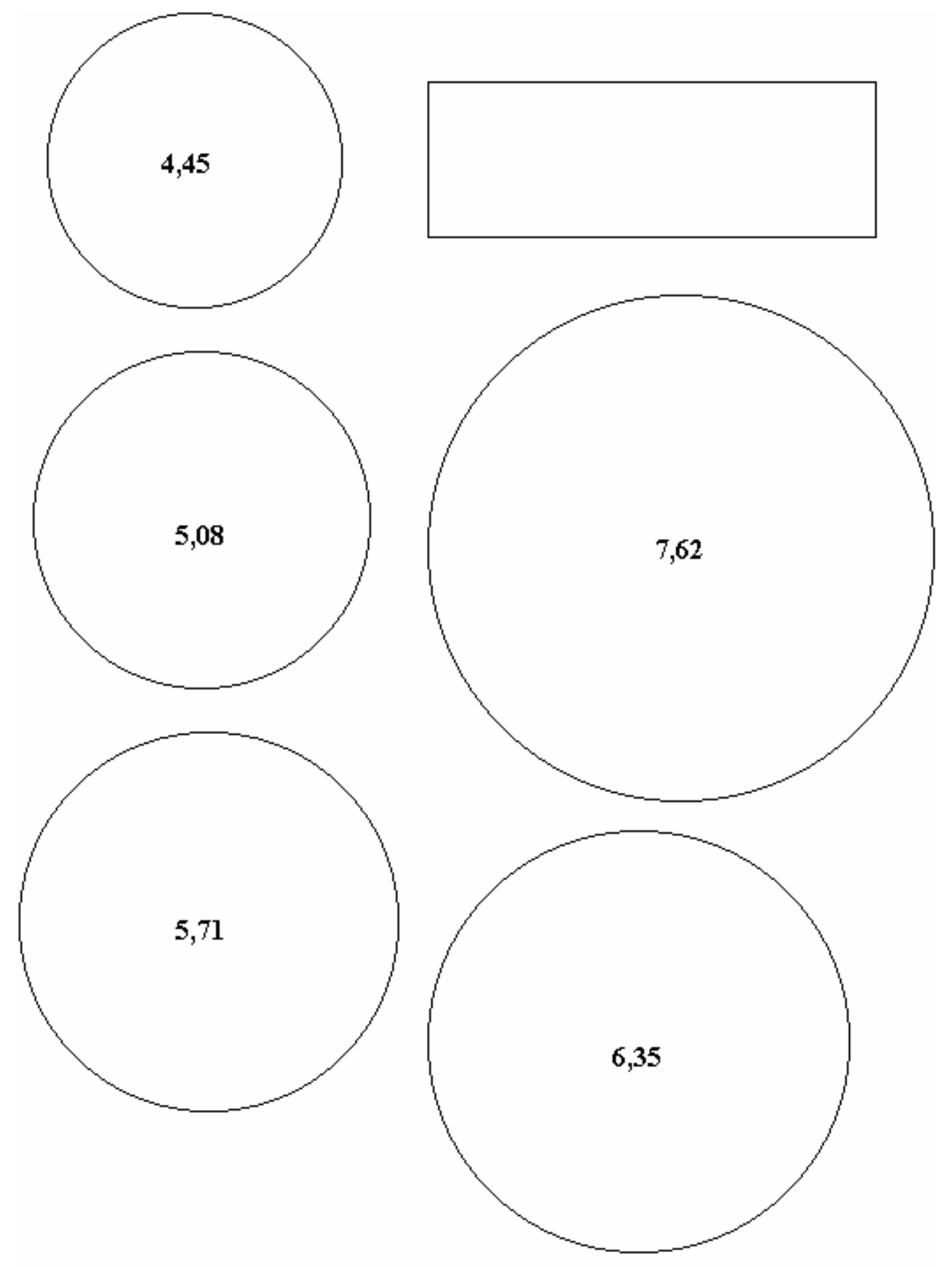

Figura 4 - Gabarito de medições (cm)

Fonte: Estados Unidos (1999) 


\subsubsection{Depenagem e resíduos de pele}

Foi avaliada a presença de penas, pelos e resíduos de pele nas carcaças e cortes segundo os requerimentos do Quadro 1 e 2.

\subsubsection{Carne exposta, cortes, dilaceramento e ossos quebrados}

Verificou-se na carcaça a presença de cortes de pele, ossos quebrados e desarticulados, e nos cortes verificou-se o excesso de perda de pele como conseqüência do corte da desossa deixando a carne exposta de acordo com o Quadro 1 e 2.

\subsubsection{Descolorações na pele, manchas e hematomas na carne}

Foram realizados medições nas áreas com defeitos na cor, a qual determina o grau de descoloração, hematoma, hemorragias ou coágulos nas carcaças e cortes, classificando as carcaças e cortes de acordo com o Quadro 1 e 2. Considera-se hematoma uma área de cor vermelha a roxa na pele ou superfície da carne, decorrente de uma contusão. 


\begin{tabular}{|c|c|c|c|}
\hline Característica $^{1}$ & $\mathbf{A}$ & B & C \\
\hline \begin{tabular}{|l|} 
Conformação: \\
Peito, dorso, perna \\
\end{tabular} & Normal, ligeira curva. & Moderada, curva ou arqueada. & Seriamente curva ou arqueada. \\
\hline $\begin{array}{l}\text { Conteúdo de carne: } \\
\text { Peito }\end{array}$ & $\begin{array}{l}\text { Bem carnudo, grande, aparência } \\
\text { arredondada }\end{array}$ & Regular, sem aparência magra. & Deficiente de carne. \\
\hline $\begin{array}{l}\text { Perna } \\
\text { Asa }\end{array}$ & $\begin{array}{l}\text { Carnuda, aparência roliça. } \\
\text { Moderadamente carnudo. }\end{array}$ & Regular sem aparência magra. & Deficiente de carne. \\
\hline Gordura & $\begin{array}{l}\text { Boa na área da pele e folículo das } \\
\text { penas. }\end{array}$ & \begin{tabular}{|l}
$\begin{array}{l}\text { Regular cobertura em peito, } \\
\text { pernas. }\end{array}$ \\
\end{tabular} & Insuficiente, translúcido. \\
\hline \begin{tabular}{|l|} 
Depenagem: \\
Permitido por área \\
$\left(1,27 \mathrm{~cm}^{2}\right)$ \\
\end{tabular} & $\begin{array}{l}\text { Ausência de penas. } \\
\text { Máx. } 4 \text { penas. }\end{array}$ & $\begin{array}{l}\text { Ausência de penas. } \\
\text { Máx. } 6 \text { penas. }\end{array}$ & $\begin{array}{l}\text { Ausência de penas. } \\
\text { Máx. } 8 \text { penas. }\end{array}$ \\
\hline $\begin{array}{l}\text { Descolorações, } \\
\text { hematomas: } \\
\text { Peito e perna } \\
\text { O resto } \\
\end{array}$ & $\begin{array}{l}\text { Leves, sem sangrado incompleto. } \\
\text { Máx. } 2,54 \mathrm{~cm} . \\
\text { Máx. } 5,08 \mathrm{~cm} .\end{array}$ & $\begin{array}{l}\text { Moderadas, pequenas evidencia } \\
\text { de sangrado. } \\
\text { Máx. } 5,08 \mathrm{~cm} . \\
\text { Máx. } 7,62 \mathrm{~cm} .\end{array}$ & $\begin{array}{lll}\text { Sem limite em área nem } \\
\text { intensidade. } & & \\
\text { Sem limite em área. } & & \\
\text { Sem limite em área. } & & \\
\end{array}$ \\
\hline $\begin{array}{l}\text { Deslocados e ossos } \\
\text { quebrados }\end{array}$ & $\begin{array}{l}\text { Sem ossos quebrados e deslocados } \\
\text { (exceto quadril com dorso, perna ou } \\
\text { quartos de perna). Com o sem ponta } \\
\text { de asa, pigostilio. A cartilagem é } \\
\text { considerada como deslocado. }\end{array}$ & $\begin{array}{l}\text { Sem ossos quebrados. } \\
\text { Permitem-se ossos deslocados. } \\
\text { Com o sem ponta de asa após a } \\
\text { segunda união. }\end{array}$ & $\begin{array}{l}\text { Sem limite. } \\
\text { Com o sem pigostilio. } \\
\text { Com o sem ponta. }\end{array}$ \\
\hline Partes para retirar & $\begin{array}{l}\text { Pontas de asa e pigostilio. } \\
\text { Ponta de asa após segunda união. }\end{array}$ & \begin{tabular}{|l|} 
Pontas de asas e pigostilio. \\
Ponta de asa após segunda união.
\end{tabular} & $\begin{array}{l}\text { Pontas de asas (após segunda } \\
\text { união) e pigostilio. }\end{array}$ \\
\hline Partes de carcaças & Não é permitido. & $\begin{array}{l}\text { Pode-se retirar uma quantidade } \\
\text { ao redor dos defeitos. }\end{array}$ & $\begin{array}{l}\text { Pode-se retirar uma quantidade ao } \\
\text { redor dos defeitos. }\end{array}$ \\
\hline
\end{tabular}

Quadro 1 - Classificação de carcaças de Frango

${ }^{1}$ Estados Unidos (1999, 2002) 


\begin{tabular}{|c|c|c|c|}
\hline Características $^{1}$ & A & $\mathbf{B}$ & $\mathbf{C}$ \\
\hline $\begin{array}{l}\text { Depenagem: } \\
\text { Permitido por área } \\
\left(1,27 \mathrm{~cm}^{2}\right)\end{array}$ & $\begin{array}{l}\text { Livre de penas e pelos. } \\
\text { Máx. } 2 \text { penas. }\end{array}$ & $\begin{array}{l}\text { Algumas penas e pelos. } \\
\text { Máx. } 3 \text { penas. }\end{array}$ & $\begin{array}{l}\text { Algumas penas e pelos. } \\
\text { Máx. } 4 \text { penas. }\end{array}$ \\
\hline $\begin{array}{l}\text { Carne exposta: } \\
\text { Peito e perna } \\
\text { O resto }\end{array}$ & $\begin{array}{l}\text { Não deve afetar a aparência do } \\
\text { corte, permitido }<75 \% . \\
\text { Máx. } 0,635 \mathrm{~cm} . \\
\text { Máx. } 1,905 \mathrm{~cm} .\end{array}$ & $\begin{array}{l}\text { Máximo } 1 / 3 \text { da carne coberta por } \\
\text { pele. }\end{array}$ & Sem limite. \\
\hline Descolorações, hematomas: & $\begin{array}{l}\text { Não permitido em peito, perna } \\
\text { (exceto junta do jarrete). Livres de } \\
\text { coágulos, sem sangramento } \\
\text { incompleto (folículo das penas). }\end{array}$ & Leves ou moderadas tonalidades. & Sem limite. \\
\hline $\begin{array}{l}\text { Peito e perna } \\
\text { O resto }\end{array}$ & $\begin{array}{l}\text { Máx. } 0.953 \mathrm{~cm} . \\
\text { Máx. } 1,905 \mathrm{~cm} .\end{array}$ & Máx $2,54 \mathrm{~cm}$. & \\
\hline
\end{tabular}

Quadro 2 - Classificação de cortes de Frango

${ }^{1}$ Estados Unidos (1999, 2002) 


\subsection{Avaliação de atributos de qualidade}

Nesta etapa foi utilizado um total de 180 carcaças de frango, sendo 60 frangos em cada repetição. Após resfriamento no chiller foram desossadas as carcaças. Os cortes de peito, coxa e sobrecoxa foram colocados em embalagens de PVC sendo transportados até o laboratório de carnes do LAN/ESALQ e CTC/ITAL para os análises respectivas, sendo armazenados em câmara fria com temperatura de aproximadamente $0 \pm 2{ }^{\circ} \mathrm{C}$.

Foi feita uma avaliação do rendimento das carcaças e uma caracterização dos atributos de qualidade dos cortes de peito, coxa e sobrecoxa realizando-se análise de composição centesimal (teor umidade, gordura, cinzas e proteínas) cinco horas após o abate. Também foram feitas as análises de perda de peso por cozimento, capacidade de retenção de água (CRA), força de cisalhamento, cor, $\mathrm{pH}$, teor de proteína às 5, 24, 48 e 72 horas após o abate, enquanto a análise sensorial foi avaliada às 24, 48 e 72 horas após o abate.

\subsubsection{Determinação do rendimento}

As 180 aves foram pesadas na granja antes do jejum alimentar e na chegada ao abatedouro. Após a evisceração, pesou-se a carcaça quente (antes do resfriamento no chiller) e fria (após o resfriamento no chiller). O rendimento foi calculado dividindo-se o peso de carcaça fria pelo peso das aves vivas após o jejum, peso abate; e expresso em porcentagem.

\subsubsection{Análises físicas}

\subsubsection{Cor instrumental}

A avaliação da cor foi feita com o uso de um colorímetro Minolta Chroma Meter CR-508d. As medições foram feitas no sistema CIELab com os parâmetros L* (luminosidade), a* (intensidade de vermelho) e $b^{*}$ (intensidade de amarelo), e com as 
seguintes características: área de medição $8 \mathrm{~mm}$ de diâmetro, ângulo de observação $10^{\circ}$, iluminante D65 com componente especular incluído. Para cada tratamento foi utilizado um total de 24 amostras de três repetições para cada tipo de corte de peito, coxa e sobrecoxa, e colocadas num prato de fundo branco sendo feita a leitura da cor no lado interno do músculo, obtendo-se os resultados de cinco leituras em diferentes regiões para cada amostra.

\subsubsection{Perda de peso por cozimento}

A determinação da perda de peso por cozimento foi realizada pelo registro dos pesos das amostras antes e após o cozimento. Um total de 24 amostras de cada corte de peito, coxa e sobrecoxa foram embrulhadas em papel alumínio e cozidas na grelha por aproximadamente 10 minutos, até atingirem a temperatura interna de $82{ }^{\circ} \mathrm{C}$, segundo o método descrito por Mead (1987). A diferença entre o peso inicial e final correspondeu a perda de peso por cozimento, sendo expresso em porcentagem.

\subsubsection{Força de cisalhamento}

Foi determinada por meio de um analisador de textura TA-XT2 da Stable Micro System (Warner-Bratzler), com velocidade de $20 \mathrm{~cm} / \mathrm{min}$ e força de $5 \mathrm{~kg}$. As 24 amostras de três repetições de cada corte de peito de frango foram cozidas na grelha até atingirem $85{ }^{\circ} \mathrm{C}$ segundo o método descrito por Mead (1987); e logo após foram esfriadas e armazenadas por $24 \mathrm{~h}$ a $5{ }^{\circ} \mathrm{C}$. Utilizou-se 20 amostras por cada corte de peito, os quais foram cortadas em forma de paralelepípedo de $2 \mathrm{~cm} \times 1 \mathrm{~cm} \times 1 \mathrm{~cm}$, conforme a metodologia proposta por Froning \& Uijtteenboogaart (1988). Os resultados foram expressos em kgf.cm ${ }^{-2}$. 


\subsubsection{Capacidade de retenção de água (CRA)}

Utilizou-se a metodologia descrita por Nakamura \& Katoh (1985), que baseou-se na pesagem acurada de aproximado $1 \mathrm{~g}$ de carne cru em papel filtro, e colocou-as em centrifuga à $1500 \mathrm{G}$ por um período de tempo de 4 min. Após centrifugação, a amostra foi pesada e em seguida colocada na estufa a $70{ }^{\circ} \mathrm{C}$ durante 12 horas. O valor de CRA foi determinado pela diferença entre o peso da amostra após centrifugação e o peso da amostra seca, dividida pelo peso final: sendo o valor expresso em porcentagem. $\mathrm{O}$ número de amostras utilizado foi 3 por cada tipo de corte em cada repetição, com um total de 9 amostras por cada corte de peito, coxa e sobrecoxa.

\subsubsection{Análises químicas}

\subsubsection{1 pH}

Utilizou-se um total de nove amostras em três repetições para cada corte de peito, coxa e sobrecoxa. A medição foi feita num potenciômetro digital marca Digimed DM2, com eletrodo de punção. As medições foram tomadas em quatro pontos nos músculos de peitos e três pontos nas coxas e sobrecoxas de frango.

\subsubsection{Teor de umidade}

A determinação foi feita pelo processo gravimétrico, de acordo com Association of Official Analytical Chemistry (AOAC, 1998), utilizou-se secagem das amostras de peito, coxa e sobrecoxa de frango em estufa a aproximadamente $105^{\circ} \mathrm{C}$, até atingir peso constante $(24 \mathrm{~h})$. Para cada corte de peito, coxa e sobrecoxa foram utilizadas um total de 9 amostras. 


\subsubsection{Teor de proteína}

Foi utilizado um total de nove amostras por repetição para cada corte. Determinouse pelo método semi-microkjeldahl segundo o descrito pela AOAC (1998). As amostras pesadas foram digeridas com uma mistura digestora e destiladas posteriormente sendo o nitrogênio recebido numa solução de ácido bórico com solução indicadora e logo foram tituladas com $\mathrm{H}_{2} \mathrm{SO}_{4}$. Para o cálculo do valor de proteína utilizou-se o fator de conversão de 6,25 .

\subsubsection{Teor de lipídeos}

Foi determinado pelo método gravimétrico utilizando-se extrator Soxhlet conforme o método descrito pela AOAC (1998). Foram pesadas aproximadamente $2 \mathrm{~g}$ das amostras e colocadas em cartuchos para serem introduzidas no balão; montou-se o extrator e utilizou-se hexano como solvente por um período de 10 horas; após foi levado para estufa de $70^{\circ} \mathrm{C}$ até secagem do solvente sendo feito o calculo gravimétrico. Foram utilizadas 9 amostras por cada tipo de corte de peito, coxa e sobrecoxa.

\subsubsection{Avaliação Sensorial}

As análises sensoriais foram realizadas conforme Moraes (1983), sendo avaliados os atributos de maciez, suculência e sabor característico de frango. Utilizou-se uma equipe de 12 provadores selecionados e treinados. Foi utilizado um total de 18 amostras de cada corte de peito, coxa e sobrecoxa de frango de criação alternativa obtida do abatedouro da Korin Agropecuária e convencional obtido do abatedouro Fricock (Rio Claro). As amostras em estudos de carne de peito, coxa e sobrecoxa de frangos de criação alternativas foram comparadas com os frangos de criação convencional sob as mesmas condições de abate e armazenamento, nos períodos de 24, 48 e $72 \mathrm{~h}$ após abate. Utilizou-se uma escala não estruturada de $10 \mathrm{~cm}$, onde os extremos representam de 
pouco (0) e muito (10) para maciez, suculência e sabor característico. As amostras foram preparadas segundo as recomendações feitas por Mead (1987). Logo foram cortadas em fatias de cerca de aproximadamente $1 \mathrm{~cm}$ e servidas à temperatura de $40-50{ }^{\circ} \mathrm{C}$ em copos de plásticos codificados com três dígitos e com ordem de apresentação variada.

\subsection{Análise Estatística}

Na classificação de carcaças e cortes os dados foram submetidos à análise de discriminante, técnica multivariada, que tem como objetivo o estudo do padrão de diferenciação de distintos grupos (classificação). Foi utilizada a função discriminante linear de Fisher $\left(\mathrm{Y}=\beta_{0}+\beta_{1} \mathrm{X}\right)$, onde: $\mathrm{Y}$ são as classes $\mathrm{A}, \mathrm{B}$ ou $\mathrm{C}$ e $\mathrm{X}$ eqüivale à área de hematoma. Adicionalmente foi feita uma análise de variância.

$\mathrm{Na}$ avaliação dos atributos de qualidade dos cortes de peito, coxa e sobrecoxa foi feita a análise de variância, avaliação de medias (Teste de Turkey, $\mathrm{p}<0,05$ ), regressão múltipla, correlação simple de Pearson e análises de correspondência. 


\section{RESULTADOS E DISCUSSÃO}

\subsection{Classificação de carcaças e cortes de frango}

A classificação de carcaça e cortes de frango foi feita tendo como variável a presença de hematomas, pois foi a característica de classificação mais significativa, e classificadas em classe A, B ou C como é mostrado na Figura 5. Por isto, a análise discriminante foi utilizada para verificar se as carcaças e cortes foram corretamente classificados.

\subsubsection{Carcaças de frango}

Na Tabela 1, observa-se a porcentagem de defeitos nas carcaças de frango, com presença de hematomas em 79,73 \% das amostras. Na Figura 5 mostra-se a classificação das carcaças de frango em classe A, B e C. O número total de carcaças analisadas foi 198, 39 e 64 para classe A, B e C, respectivamente.

De acordo com a classificação americana (Mendes, 2001), os trabalhos têm demonstrado que cerca de $32 \%$ das carcaças atingem a classe A (ausência de defeitos); os $15 \%$ das carcaças apresentam hematomas, $5 \%$ de arranhões e corte de pele, $2 \%$ de fraturas, variando de acordo a densidade das aves. As porcentagens variam de 12,5 e $17,50 \%$ de hematomas, 20 e 25,62 \% de arranhões para densidades de 12 e 16 aves $/ \mathrm{m}^{2}$, respectivamente. Na presente pesquisa, apenas $29,27 \%$ das carcaças não apresentaram nenhum tipo de hematomas, sendo classificados como classe A; a porcentagem de 
hematomas foi maior, porém, obtivesse menores valores para porcentagem de arranhões de acordo com a densidade de aves de 12 aves $/ \mathrm{m}^{2}$.

Tabela 1. Defeitos encontrados nas carcaças de frango

\begin{tabular}{lcccccccc}
\hline & \multicolumn{2}{c}{$\mathrm{A}$} & \multicolumn{2}{c}{$\mathrm{B}$} & \multicolumn{2}{c}{$\mathrm{C}$} & \multicolumn{2}{c}{ TOTAL } \\
& $\mathrm{N}$ & $\%$ & $\mathrm{~N}$ & $\%$ & $\mathrm{~N}$ & $\%$ & $\mathrm{~N}$ & $\%$ \\
\hline Sem hematomas & 59 & 29,80 & - & - & 2 & 3,13 & 61 & 20,27 \\
Com hematomas & 139 & 70,20 & 39 & 100,00 & 62 & 96,88 & 240 & 79,73 \\
TOTAL & $\mathbf{1 9 8}$ & 65,78 & $\mathbf{3 9}$ & 12,96 & $\mathbf{6 4}$ & 21,26 & $\mathbf{3 0 1}$ & 100,00 \\
Hematomas peito & 45 & 22,73 & 13 & 33,33 & 21 & 32,81 & 79 & 26,25 \\
Hematomas dorso & 17 & 8,59 & 9 & 23,08 & 23 & 35,94 & 49 & 16,28 \\
Hematomas perna & 48 & 24,24 & 23 & 58,97 & 38 & 59,38 & 109 & 36,21 \\
Hematomas asa & 97 & 48,99 & 29 & 74,36 & 54 & 84,38 & 180 & 59,80 \\
Avermelhamento & 56 & 28,28 & - & - & 4 & 6,25 & 60 & 19,93 \\
Aranhões & 35 & 17,68 & - & - & 3 & 4,69 & 38 & 12,62 \\
Corte de pele & 24 & 12,12 & 6 & 15,38 & 7 & 10,94 & 37 & 12,29 \\
Depenagem & 30 & 15,15 & 8 & 20,51 & 12 & 18,75 & 50 & 16,61 \\
Resíduo de pele & 112 & 56,57 & 12 & 30,77 & 30 & 46,88 & 154 & 51,16 \\
Fraturas & - & - & - & - & 22 & 34,38 & 22 & 7,31 \\
Escoriações & 6 & 3,03 & 1 & 2,56 & - & - & 7 & 2,33 \\
Intumescimento asa & 26 & 13,13 & - & - & 1 & 1,56 & 27 & 8,97 \\
\hline N: número carcach & & & & - & & & &
\end{tabular}

$\mathrm{N}$ : número de carcaças

Segundo Leandro et al. (2001), 20 - 30 \% dos hematomas são produzidos antes, 30 - $50 \%$ durante e 20 - $35 \%$ após a apanha. Além disso, densidade, calor, cama dura, apanha e acomodação nas gaiolas, transporte e atordoamento são etapas importantes do processo de abate. 

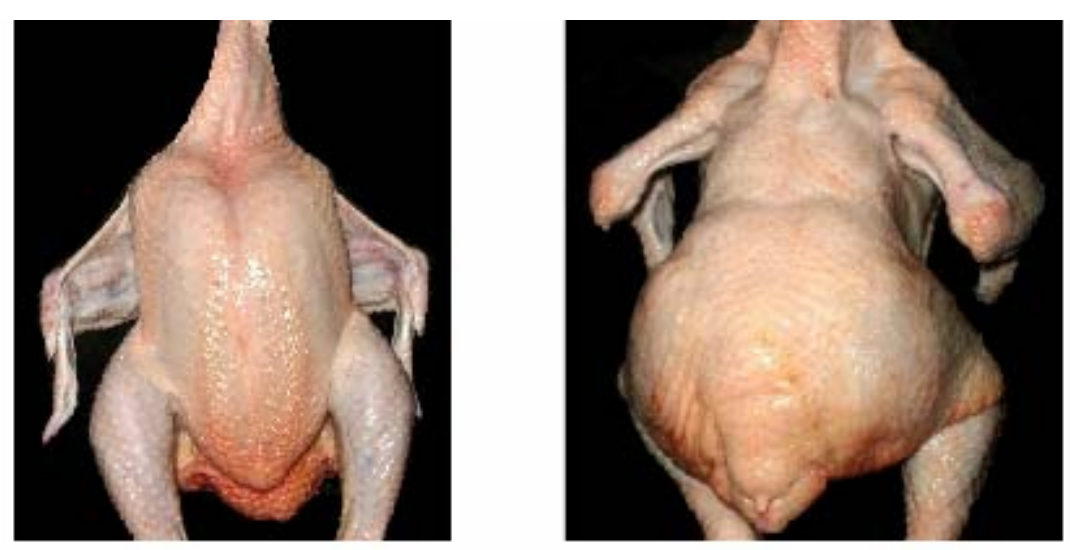

Classe A

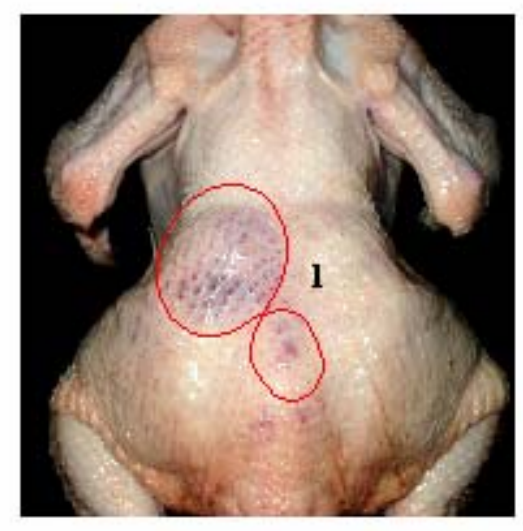

Classe B

(1) hematomas
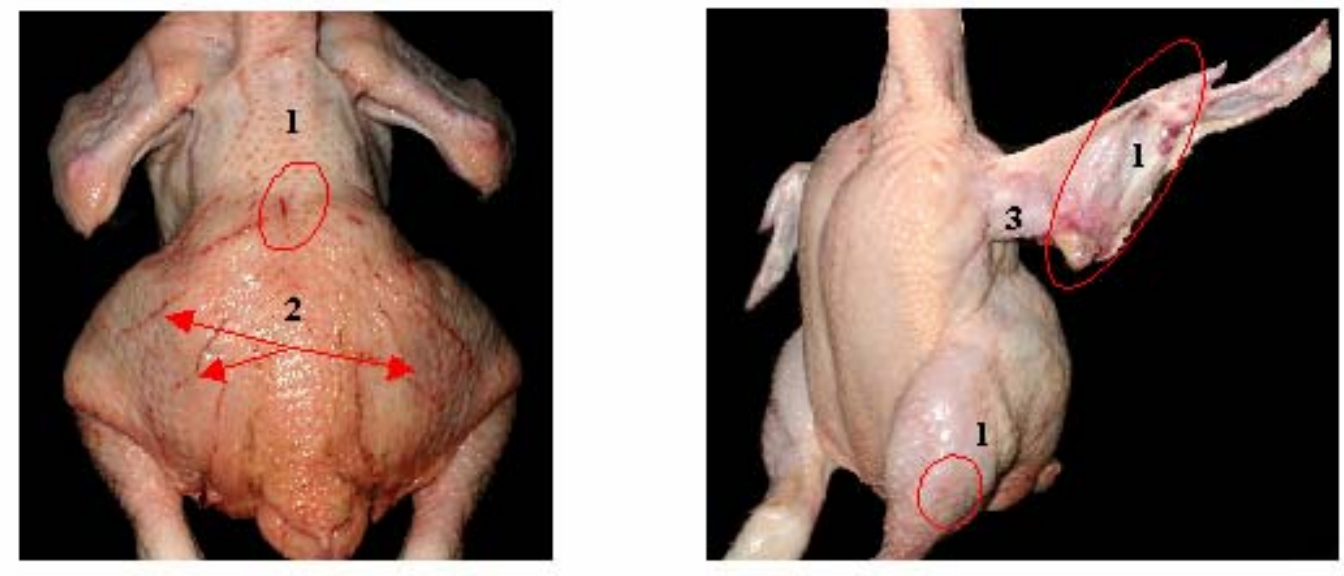

Classe C

(1) hematomas, (2) aranhões, (3) deslocados

Figura 5 - Classificação de carcaças 
Farsaie et al. (1983) e Ekstrand (1998), reportaram que as aves chegaram a planta com 0,022 a $25 \%$ de contusões, e outros indicaram que faixa de 0,05 a 0,57\% de morte das aves é produzida entre o momento da apanha e chegada a abatedouro (Warris et al., 1992; Ekstrand, 1998 e Bayliss \& Hinton, 1990).

Mendes (2001) e Reali (1994), observaram que contusões apresentadas pela apanha foram de $11,32,8$ e 38,2 \% para peito, coxa e asas, respectivamente. A taxa de contusões apresentadas no peito e asa foi significativamente afetada pelo tempo de transporte do galpão até a descarga na plataforma, tendo correlação positiva para a incidência de contusões no peito e negativa para as asas; assim como correlação positiva entre a densidade de criação e contusões de asas (Carlyle et al., 1997). Segundo observações realizadas no trabalho, as regiões com hematomas foram $26,25 \%$ no peito, $16,28 \%$ no dorso, 36,21 \% na perna e 59,80 \% na asa (Tabela 1); supõe-se que a presença de hematomas tenha ocorrido principalmente pelo processo de apanha e problemas de abate (escaldagem e depenagem) pela avaliação do processo em forma geral.

$\mathrm{Na}$ tabela 2, são indicadas as médias de área de hematoma para cada classe; observa-se que existe diferença significativa entre as classes. Foi utilizada a análise discriminante e obteve-se que a classe A foi bem classificada em 83,5 \%, sendo que 16,5 $\%$ pertenceriam à classe $\mathrm{B}$; o nível $\mathrm{B}$ foi corretamente classificado; entretanto a classe $\mathrm{C}$ teve $79 \%$ de acerto na classificação; assim o $21 \%$ deveria corresponder à classe A $(9,7$ $\%)$ e B $(11,3 \%)$. Em geral 84,9 \% das carcaças foram bem classificadas de acordo com o padrão da qualidade dos Estados Unidos.

Tabela 2. Predição dos membros do grupo para classificação de carcaça $(\mathrm{p}<0,05)$

\begin{tabular}{ccccccccc}
\hline Classe & Área de & \multicolumn{2}{c}{ A } & \multicolumn{2}{c}{ B } & \multicolumn{2}{c}{ Total } \\
& Hematoma $(\mathrm{cm})$ & $\mathrm{N}$ & $\%$ & $\mathrm{~N}$ & $\%$ & $\mathrm{~N}$ & $\%$ & $\mathrm{~N}$ \\
\hline $\mathrm{A}$ & $3,49^{\mathrm{c}} \pm 1,65$ & 115 & 83,5 & 23 & 16,5 & - & - & 139 \\
$\mathrm{~B}$ & $7,32^{\mathrm{b}} \pm 0,80$ & - & - & 39 & 100,0 & - & - & 39 \\
$\mathrm{C}$ & $10,98^{\mathrm{a}} \pm 4,11$ & 6 & 9,7 & 7 & 11,3 & 49 & 79,0 & 62 \\
\hline
\end{tabular}

N: número de carcaças. 


\subsubsection{Cortes de frango}

Na Tabela 3, observa-se a porcentagem de defeitos nos cortes de peito, coxa e sobrecoxa de frango (Figura 6 e 7). O principal defeito encontrado foi a presença de hematomas para todos os cortes; observa-se que a maioria dos cortes foram classificados como A e B. Entretanto, existem outros defeitos que poderiam ser melhorados no processamento como a depenagem e resíduo de pele, assim como a carne exposta .

Tabela 3. Defeitos encontrados nos cortes de frango (\%)

\begin{tabular}{lccccccccc}
\hline & \multicolumn{3}{c}{ PEITO } & \multicolumn{4}{c}{ COXA } & \multicolumn{4}{c}{ SOBRECOXA } \\
& A & B & C & A & B & C & A & B & C \\
& 71,23 & 15,75 & 12,02 & 37,41 & 32,41 & 30,18 & 46,21 & 31,03 & 22,76 \\
\hline Sem hematoma & 62,50 & - & - & 74,55 & - & - & 68,66 & - & - \\
Com hematoma & 37,50 & 100,0 & 100,0 & 25,45 & 100,0 & 100,0 & 31,34 & 100,0 & 100,0 \\
Carne exposta & 15,38 & 4,35 & 21,05 & 32,73 & 42,55 & 42,22 & 7,46 & 8,89 & 9,09 \\
Depenagem & 29,81 & 17,39 & 26,32 & 27,27 & 19,15 & 26,67 & 37,31 & 22,22 & 24,24 \\
Resíduo de pele & 30,77 & 43,48 & 47,37 & 56,36 & 46,81 & 33,33 & 59,70 & 26,67 & 24,24 \\
Fraturas & - & - & - & - & - & 4,44 & - & - & - \\
\hline
\end{tabular}

Para o peito, apenas 37,5 \% das amostras apresentaram hematomas e segundo a área foram classificados em A, B ou C (Tabela 3). As comparações das médias de área de hematoma estão indicadas na Tabela 4. De acordo com a análise discriminante a classe A foi corretamente classificada, no entanto, as classes B e C tiveram 17,4 e 31,6 $\%$ de cortes não classificados corretamente. Porém a análise geral indicou que 87,7 \% dos cortes de peito foram bem classificados.

Na Tabela 5 são indicadas as médias da área de hematoma para coxa, foi comprovado que existe diferença significativa entre as classes A, B e C. De acordo com a análise discriminante, 96,2 \% dos cortes de coxa foram bem classificados. As classes A e C tiveram $100 \%$ de acerto na classificação, entretanto 10,6 \% das amostras da classe B não foram corretamente classificadas. 


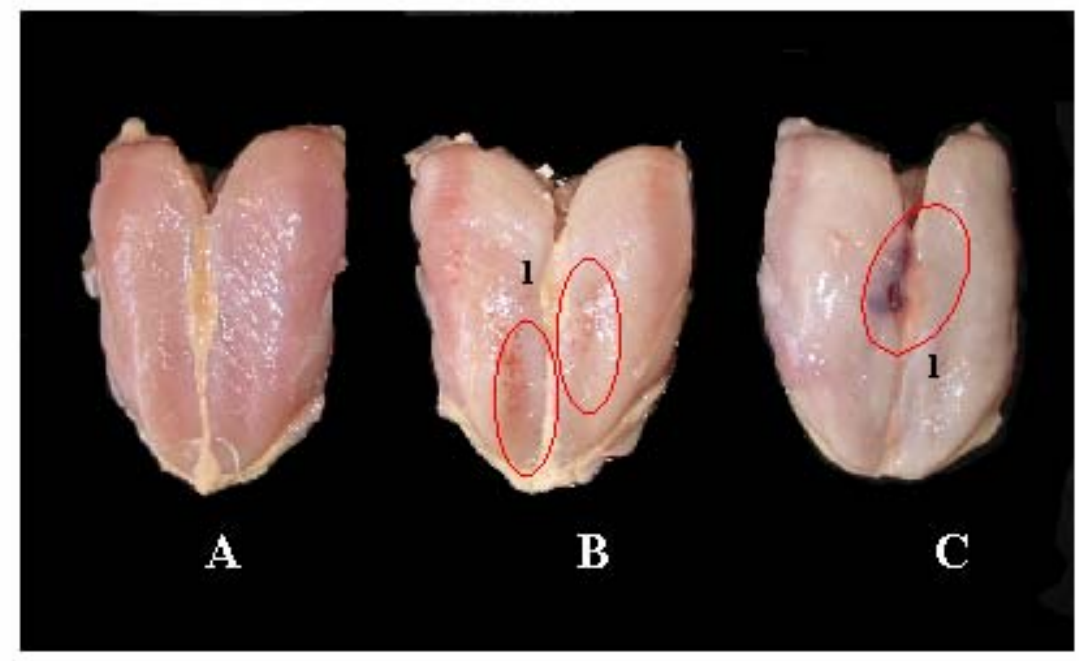

Figura 6 - Classificação de corte de peito: (1) hematomas

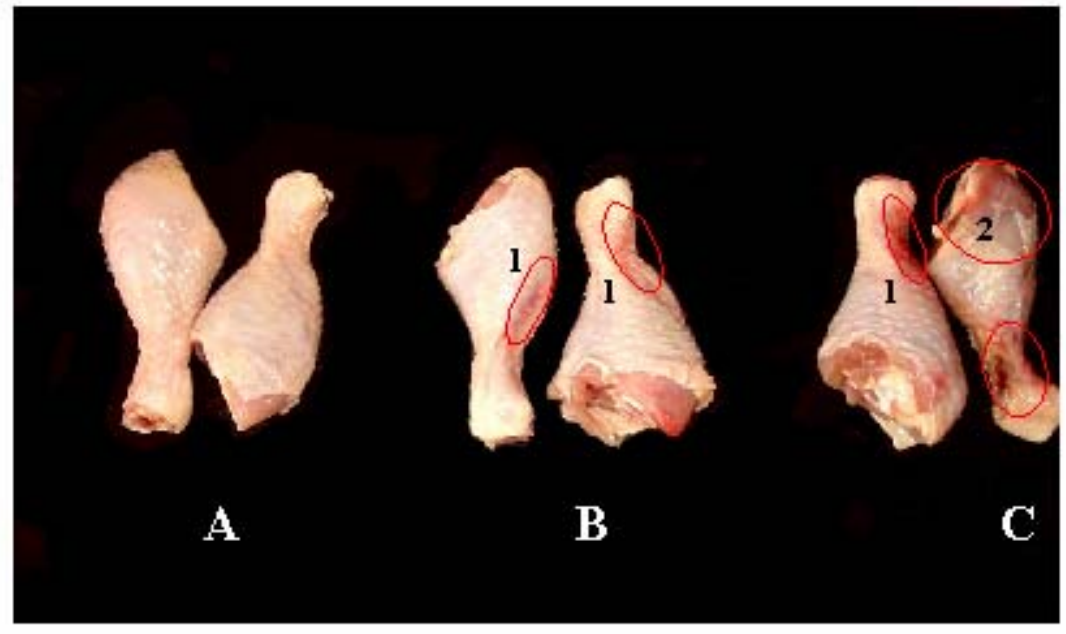

Figura 7 - Classificação de corte de coxa: (1) hematomas, (2) carne exposta 
Tabela 4. Predição dos membros do grupo para classificação de corte de peito $(\mathrm{p}<0,05)$

\begin{tabular}{ccccccccc}
\hline Classe & Área de & \multicolumn{2}{c}{ A } & \multicolumn{2}{c}{ B } & \multicolumn{2}{c}{ Cotal } \\
& Hematoma $(\mathrm{cm})$ & $\mathrm{N}$ & $\%$ & $\mathrm{~N}$ & $\%$ & $\mathrm{~N}$ & $\%$ & $\mathrm{~N}$ \\
\hline $\mathrm{A}$ & $0,64^{\mathrm{c}} \pm 0,24$ & 39 & 100,0 & - & - & - & - & 39 \\
$\mathrm{~B}$ & $2,03^{\mathrm{b}} \pm 0,60$ & 4 & 17,4 & 19 & 82,6 & - & - & 23 \\
$\mathrm{C}$ & $5,24^{\mathrm{a}} \pm 3,00$ & - & - & 6 & 31,6 & 13 & 68,4 & 19 \\
\hline
\end{tabular}

$\mathrm{N}$ : número de carcaças.

Tabela 5. Predição dos membros do grupo para classificação de corte de coxa $(\mathrm{p}<0,05)$

\begin{tabular}{ccccccccc}
\hline Classe & Área de & \multicolumn{2}{c}{ A } & \multicolumn{2}{c}{ B } & \multicolumn{2}{c}{ Total } \\
& Hematoma $(\mathrm{cm})$ & $\mathrm{N}$ & $\%$ & $\mathrm{~N}$ & $\%$ & $\mathrm{~N}$ & $\%$ & $\mathrm{~N}$ \\
\hline $\mathrm{A}$ & $0,79^{\mathrm{c}} \pm 0,21$ & 14 & 100,0 & - & - & - & - & 14 \\
$\mathrm{~B}$ & $1,94^{\mathrm{b}} \pm 0,45$ & 5 & 10,6 & 42 & 89,4 & - & - & 47 \\
$\mathrm{C}$ & $4,17^{\mathrm{a}} \pm 1,07$ & - & - & - & - & 44 & 100,0 & 44
\end{tabular}

$\mathrm{N}$ : número de carcaças.

$\mathrm{Na}$ Tabela 6, observa-se a média das áreas de hematoma na sobrecoxa, e existe diferença significativa entre as classes. Segundo a análise discriminante, em geral, $95 \%$ dos cortes foram corretamente classificados; as classes A e B foram bem classificadas (100\%), enquanto que a classe $\mathrm{C}$ teve $15,2 \%$ de carcaças pertencentes à classe $\mathrm{B}$.

Tabela 6. Predição dos membros do grupo para classificação de corte de sobrecoxa

\begin{tabular}{cccccccccc} 
& $(\mathrm{p}<0,05)$ & & & & & & & \\
Classe & Área de & \multicolumn{2}{c}{ A } & & B & & C & Total \\
& Hematoma $(\mathrm{cm})$ & $\mathrm{N}$ & $\%$ & $\mathrm{~N}$ & $\%$ & $\mathrm{~N}$ & $\%$ & $\mathrm{~N}$ \\
\hline $\mathrm{A}$ & $0,69^{\mathrm{c}} \pm 0,25$ & 22 & 100,0 & - & - & - & - & 22 \\
$\mathrm{~B}$ & $1,85^{\mathrm{b}} \pm 0,50$ & - & - & 45 & 100,0 & - & - & 45 \\
$\mathrm{C}$ & $4,65^{\mathrm{a}} \pm 1,49$ & - & - & 5 & 15,2 & 28 & 84,8 & 33
\end{tabular}

$\mathrm{N}$ : número de carcaças. 
Os cortes de frango que não se classificaram corretamente, deve-se às áreas de hematomas que se encontram no limite do aceitável de cada classe, além disso, existem defeitos que não são permitidos em A e B, pelo que foram classificadas como classe C.

Nas amostras de peito, não foi observada diferença significativa entre as médias de CRA das classes A e B (Tabela 7). Quanto ao CRA da coxa (Tabela 8), segundo a análise discriminante $(\mathrm{p}<0,05)$, mostram em geral 43,1 \% de acerto na classificação, sendo 52,6\%, $15 \%$, e 63,2 \% para as classes A, B e C respectivamente. Assim, concluise que este parâmetro não pode ser utilizado para classificar os cortes, embora a média de CRA do tipo A $(62,22 \%)$ seja superior $(\mathrm{p}<0,05)$ ao tipo $\mathrm{C}(58,79 \%)$; não foi encontrada diferença significativa entre as classes A e B $(61,30 \%)$.

Tabela 7. Predição dos membros do grupo para classificação de corte de peito $(\mathrm{p}<0,05)$

\begin{tabular}{ccccccccc}
\hline Classe & \multicolumn{3}{c}{ CRA (\%) } & \multicolumn{2}{c}{ A } & \multicolumn{2}{c}{ B } & Total \\
& Min & Máx & Média & N & $\%$ & N & $\%$ & N \\
\hline A & 44,03 & 62,69 & $59,04^{\text {a }} \pm 4,40$ & 7 & 35 & 13 & 65 & 20 \\
B & 54,27 & 63,43 & $59,11^{\text {a }} \pm 2,22$ & 12 & 54,5 & 10 & 45,5 & 22 \\
\hline
\end{tabular}

N: número de carcaças

Tabela 8. Predição dos membros do grupo para classificação de corte de coxa $(\mathrm{p}<0,05)$

\begin{tabular}{|c|c|c|c|c|c|c|c|c|c|c|}
\hline \multirow[b]{2}{*}{ Classe } & \multicolumn{3}{|c|}{ CRA (\%) } & \multicolumn{2}{|r|}{ A } & \multicolumn{2}{|c|}{ B } & \multicolumn{2}{|c|}{$\mathrm{C}$} & \multirow{2}{*}{$\begin{array}{c}\text { Total } \\
\mathrm{N}\end{array}$} \\
\hline & Min & Máx & Média & $\mathrm{N}$ & $\%$ & $\mathrm{~N}$ & $\%$ & $\mathrm{~N}$ & $\%$ & \\
\hline $\mathrm{A}$ & 54,61 & 68,67 & $62,22^{a} \pm 3,23$ & 10 & 52,6 & 6 & 31,6 & 3 & 15,8 & 19 \\
\hline B & 55,19 & 67,67 & $61,31^{b} \pm 3,97$ & 8 & 40,0 & 3 & 15,0 & 9 & 45,0 & 20 \\
\hline $\mathrm{C}$ & 51,49 & 67,58 & $58,79^{c} \pm 4,57$ & 4 & 21,1 & 3 & 15,8 & 12 & 63,2 & 19 \\
\hline
\end{tabular}

$\mathrm{N}$ : número de carcaças 


\subsection{Avaliação de atributos de qualidade}

\subsubsection{Rendimento de carcaças}

Na Tabela 9, estão apresentados os valores médios dos parâmetros avaliados durante o abate. Ao final do processo, verificou-se um rendimento médio de 66,5\% em relação ao peso de abate com a carcaça quente (antes do resfriamento) e 71,3 \% em carcaça fria (após resfriamento), respectivamente para aves com 48 - 49 dias. Mendes (2001) obteve um rendimento de 66,21 \% e Castellini et al. (2002), 70,3 e 79,5 \% para rendimento de carcaça quente e fria, respectivamente, para frangos de criação orgânica com idade de 56 dias, o rendimento pode ser afetado pelo tipo de alimentação, linhagem, idade e condições de pré-abate dos frangos.

Tabela 9. Valores médios dos pesos (g) medidos durante o abate e do rendimento (\%) de carcaças de frango

\begin{tabular}{cccccccccc}
\hline & N & PG & PA & PPJ & PCQ & PCF & PAA & RCQ & RCF \\
\hline $\mathbf{1}^{\circ}$ abate & 60 & 2736,5 & 2658,4 & 78,1 & 1744,9 & 1875,6 & 130,7 & 65,6 & 70,6 \\
$\mathbf{2}^{\circ}$ abate & 61 & 3179,3 & 3065,7 & 113,6 & 2056,3 & 2199,7 & 143,4 & 67,1 & 71,8 \\
$\mathbf{3}^{\circ}$ abate & 59 & 2911,5 & 2851,8 & 59,7 & 1902,9 & 2039,7 & 136,8 & 66,7 & 71,5 \\
Média & & 2942,4 & 2858,7 & 83,8 & 1901,4 & 2038,3 & 137,0 & 66,5 & 71,3
\end{tabular}

$\mathrm{N}$, número de carcaças; PG, peso das aves antes do jejum; PA, peso das aves no abatedouro; PPJ, perda de peso devido ao jejum; PCQ, peso da carcaça após evisceração; PCF, peso da carcaça após o chiller; PAA, peso de água absorvida; RCQ, rendimento de carcaça quente; RCF, rendimento de carcaça fria.

Observou-se alta correlação entre os parâmetros avaliados e logo foram submetidos à análise estatística de Regressão Múltipla, através do seguinte modelo:

$$
\mathrm{RCF}(\%)=\mathrm{PG}+\mathrm{PA}+\mathrm{PPJ}+\mathrm{PCQ}+\mathrm{PCF}+\mathrm{PAA}
$$

onde:

PG (g) = peso das aves antes do jejum;

PA (g) = peso das aves no abatedouro; 
PPJ (g) = perda de peso devido ao jejum (diferença entre o PG e PA);

PCQ (g) = peso da carcaça após evisceração;

PCF (g) = peso da carcaça após o chiller;

PAA (g) = peso da água absorvida no chiller (diferença entre PCQ e PCF).

Devido à alta correlação observada entre PA, PG, PCQ e PCF, o modelo final foi composto apenas por PA, PPJ e PAA, sendo a água absorvida durante o resfriamento no chiller o principal fator que influenciou no rendimento da carcaça. Pelo resultado da análise de regressão, o rendimento de carcaça frio foi considerado como uma variável dependente.

$$
\mathbf{R C Q}(\%)=65,190+0,0005678 \times \text { PA }-0,00569 \times \text { PPJ }+0,03442 \times \text { PAA }
$$

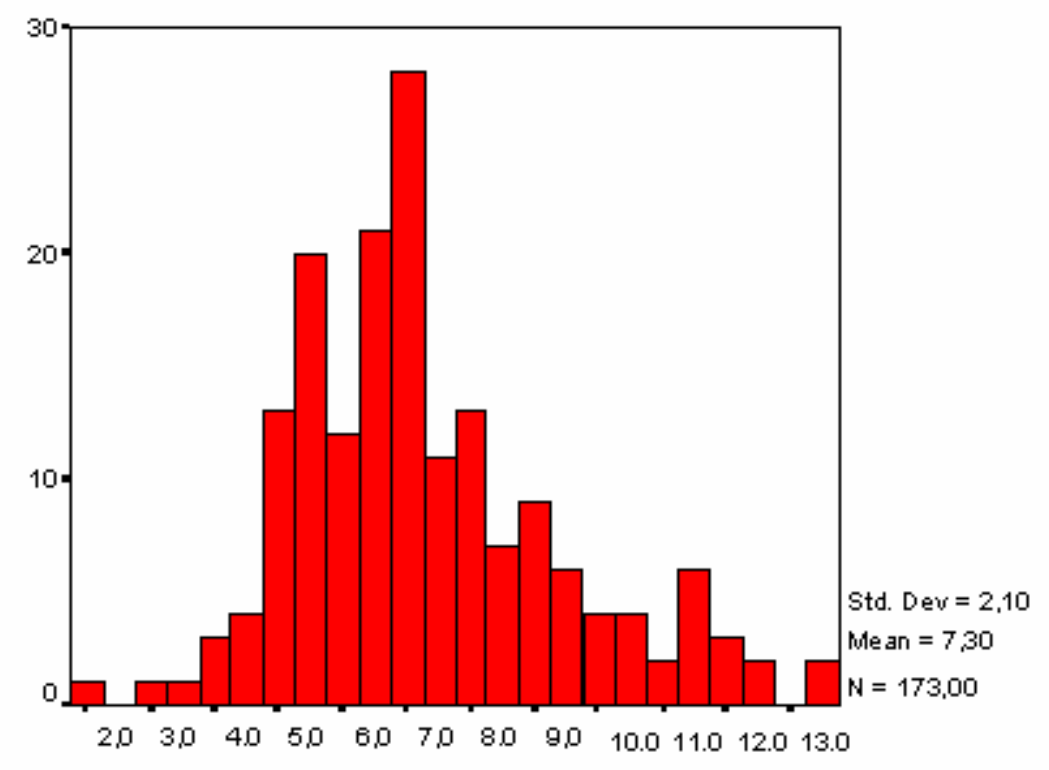

Figura 8 - Distribuição da porcentagem de água absorvida

Apesar da água absorvida ser o fator mais importante para o rendimento da carcaça, a sua porcentagem não deve ultrapassar $8 \%$, segundo a DIPOA (1998). As 
carcaças utilizadas no presente trabalho estão de acordo com a legislação brasileira, apresentando média de 7,3\% de água absorvida, sendo o valor mínimo encontrado de 2,2 e o máximo de 13,4 \% (Figura 8). Quando se observa a distribuição dos valores desta análise, verifica-se que $28,7 \%$ das amostras apresentaram porcentagem de água absorvida abaixo de $6 \%, 43,1 \%$ entre 6 e 8 , e apenas 28,2 \% ultrapassaram o $8 \%$ permitido.

\subsubsection{Análises físico-químicas}

\subsubsection{Composição centesimal}

Os resultados da análise de composição centesimal dos cortes de peito, coxa e sobrecoxa são apresentados na Tabela 10. Observa-se que o peito de frango diferiu significativamente dos cortes de coxa e sobrecoxa em relação aos teores de proteína, gordura e cinzas, com maior porcentagem de proteína e cinzas e menor teor de gordura.

Tabela 10. Valores médios da composição centesimal da carne de frango de criação alternativa

\begin{tabular}{lccccc}
\hline Corte & N & Umidade (\%) & Proteína (\%) & Gordura (\%) & Cinzas (\%) \\
\hline Peito & 9 & $75,41^{\mathrm{a}} \pm 0,5$ & $20,13^{\mathrm{a}} \pm 1,5$ & $1,57^{\mathrm{b}} \pm 0,9$ & $1,12^{\mathrm{a}} \pm 0,1$ \\
Sobrecoxa & 9 & $75,27^{\mathrm{a}} \pm 3,7$ & $16,75^{\mathrm{b}} \pm 1,2$ & $4,36^{\mathrm{a}} \pm 1,3$ & $1,02^{\mathrm{b}} \pm 0,1$ \\
Coxa & 9 & $76,94^{\mathrm{a}} \pm 0,9$ & $16,72^{\mathrm{b}} \pm 1,2$ & $5,18^{\mathrm{a}} \pm 3,2$ & $0,98^{\mathrm{b}} \pm 0,1$ \\
$\boldsymbol{P r}>\boldsymbol{F}$ & & 0,2305 & $<0,0001$ & 0,0030 & $<0,0001$ \\
\hline
\end{tabular}

Castellini et al. (2002), encontraram um teor de gordura de 0,72 e 2,47\% para peito e coxa, respectivamente, em frangos de 56 dias criados no sistema orgânico em comparação ao controle com 1,46 e 4,46 \% para peito e coxa, respectivamente. Os autores afirmaram que frangos criados no sistema orgânico têm maior atividade motora, desenvolvimento de massa muscular e redução de gordura, pois os animais produzidos são mais calmos e menos estressados, confirma que a atividade motora favorece a 
miogenesis contra a lipogenesis. Os resultado para a criação alternativa do trabalho foram menores aos de criação orgânica, porém similares aos de criação convencional encontrados no trabalho de peito de $1,57 \%$ e coxa de $5,18 \%$, devido ao tipo de alimentação, linhagem, e idade.

\subsubsection{Carne de peito}

Na Tabela 11, encontram-se os resultados das análises físico-químicas realizadas nos períodos de 5, 24, 48 e 72 horas, após abate para os corte de peito. Observa-se um decréscimo na força de cisalhamento com o decorrer do tempo, devido à resolução do processo de rigor mortis e proteólise muscular, pois durante o processo de maturação da carne ocorre a hidrólise das proteínas miofibrilares e do tecido conjuntivo, tornando a carne mais macia.

A cor (valores $\mathrm{L}^{*}$ e a*) foi alterada com as horas após abate, sendo que o valor L* (luminosidade) apresentou um acréscimo significativo, indicando que a carne de peito ficou mais clara com o tempo. O valor $\mathrm{L}^{*}$ é um parâmetro importante para a determinação da qualidade da carne, pois pode indicar problemas de PSE (pale, soft and exsudative) quando se encontra acima de 50, segundo Barbut (1996). De acordo com esse mesmo autor, a carne de peito é considerada normal quando o valor de $\mathrm{L}^{*}$ encontrase entre 45 e 50; abaixo de 45 a carne é considerada escura. No presente trabalho, as carnes de frangos não apresentaram problemas de PSE, e apenas cinco horas após abate encontrava-se escura ( $\mathrm{L}^{*}$ de 44,1). Posteriormente nos períodos de 24 até 72 horas manteve-se de 45,4 até 47,6 para o valor de L*, enquanto o valor de a* variou de 0,4 até 1,2 (Tabela 11). Os valores a* obtidos foram próximos dos encontrados por Florowski et al. (2002), porém outros autores encontraram valores desde 1,5 até 4,4 (Allen et al., 1998; Fletcher, 1999; Qiao et al., 2001). Entretanto, Castellini et al. (2002), encontraram maiores valores 60,76, 4,59 e 6,01 para $L^{*}$, a* e $b^{*}$, respectivamente, para criação orgânica. Qiao et al. (2002), valores de L* 62,07, a* 4,38 e b* 9,68, assim como Wattarachant et al. (2004) encontraram menores valores de $\mathrm{L}^{*}$ de 38,79, para a* de 0,09 e 2,53 para o valor de b* para cortes de peito. 
Tabela 11. Análises físico-químicas da carne de peito

\begin{tabular}{|c|c|c|c|c|c|c|c|c|c|c|c|}
\hline Período & $\mathbf{N}$ & $\begin{array}{c}\text { Perda peso } \\
\text { cozimento } \\
(\%)\end{array}$ & $\begin{array}{c}\text { Força de } \\
\text { Cisalhamento } \\
\left(\mathrm{kgf} . \mathrm{cm}^{-2}\right)\end{array}$ & $\mathbf{L}^{*}$ & $\begin{array}{l}\text { Cor } \\
a^{*}\end{array}$ & $\mathbf{b}^{*}$ & $\mathbf{N}$ & pH & $\begin{array}{l}\text { CRA } \\
(\%)\end{array}$ & $\begin{array}{c}\text { Proteína } \\
(\%)\end{array}$ & $\begin{array}{c}\text { Umidade } \\
(\%)\end{array}$ \\
\hline $5 \mathrm{hs}$ & 24 & $25,1^{a} \pm 2,6$ & $8,2^{a} \pm 2,4$ & $44,1^{\mathrm{b}} \pm 2,9$ & $1,0^{\mathrm{ab}} \pm 0,8$ & $7,6^{\mathrm{a}} \pm 4,2$ & 9 & $5,9^{a} \pm 0,2$ & $58,2^{\mathrm{a}} \pm 3,1$ & $20,1^{\mathrm{a}} \pm 1,5$ & $75,4^{\mathrm{a}} \pm 0,5$ \\
\hline $24 \mathrm{hs}$ & 24 & $25,6^{\mathrm{a}} \pm 4,4$ & $4,6^{\mathrm{b}} \pm 2,3$ & $45,9^{\mathrm{ab}} \pm 4,8$ & $0,4^{\mathrm{b}} \pm 1,5$ & $7,5^{\mathrm{a}} \pm 2,9$ & 9 & $5,8^{\mathrm{a}} \pm 0,2$ & $57,5^{\mathrm{a}} \pm 2,5$ & $20,2^{\mathrm{a}} \pm 1,0$ & $75,6^{\mathrm{a}} \pm 0,2$ \\
\hline $48 \mathrm{hs}$ & 24 & $26,5^{a} \pm 74$ & $3,4^{b c} \pm 0,9$ & $46,6^{\mathrm{a}} \pm 2,3$ & $1,2^{\mathrm{a}} \pm 0,8$ & $5,6^{\mathrm{a}} \pm 1,6$ & 9 & $5,7^{\mathrm{a}} \pm 0,1$ & $58,9^{\mathrm{a}} \pm 10,8$ & $20,8^{\mathrm{a}} \pm 1,0$ & $75,4^{\mathrm{a}} \pm 0,4$ \\
\hline $72 \mathrm{hs}$ & 24 & $24,5^{\mathrm{a}} \pm 3,0$ & $3,0^{\mathrm{c}} \pm 1,0$ & $47,6^{\mathrm{a}} \pm 2,8$ & $1,0^{\mathrm{ab}} \pm 0,5$ & $6,1^{\mathrm{a}} \pm 1,5$ & 9 & $5,8^{\mathrm{a}} \pm 0,2$ & $54,0^{\mathrm{a}} \pm 3,8$ & $20,5^{\mathrm{a}} \pm 0,8$ & $75,8^{\mathrm{a}} \pm 0,6$ \\
\hline $\operatorname{Pr}>F$ & & 0,5309 & $<0,0001$ & 0,0036 & 0,0431 & 0,0323 & & 0,1482 & 0,3443 & 0,5295 & 0,1382 \\
\hline
\end{tabular}

a, b,c médias dentro de cada coluna com letras diferentes são significativamente diferentes $(\mathrm{p}<0,05)$ 
$\mathrm{O}$ declino do $\mathrm{pH}$ apresenta-se como resultado da glicolise; formação de ácido láctico e redução de oxigênio no músculo (Santos et al., 2004; Schereurs, 2000 e Olivo, 1999). O pH da carne de peito após as 24 horas (Tabela 11) foi normal com os valores relatados na literatura. De acordo com Jones \& Grey (1989) e Sams \& Mills (1993), os valores normais de $\mathrm{pH}$ no final do processo de post-mortem estão entre 5,60 a 5,80 e 5,78 a 5,86, respectivamente. Diversos autores encontraram valores de $\mathrm{pH}$ entre 5,50 a 5,65 em frangos criados no sistema convencional (Lee, et al., 1976; Wood \& Richards, 1975; Florowski, et al., 2002). Encontraram maiores valores Wattarachant et al. (2004), valores de pH de 5,93 e Qiao et al. (2002), valores de 5,96 para o pH. Porém, Castellini et al. (2002) encontraram valor de pH 5,75 para o frango orgânico.

Em relação à CRA na carne de peito, apesar de não ser estatisticamente significativo, esse parâmetro apresentou uma ligeira queda no período de 72 horas, devido possivelmente à proteólise das proteínas miofibrilares, principais responsáveis por esta propriedade, não afetando a qualidade da carne de peito. Segundo a literatura, o valor encontra-se acima indicando melhor valor de CRA (Tabela 11) em comparação ao valor encontrado por Castellini et al. (2002), de 51,82 \% para frangos de criação orgânica.

Quanto a perda de peso por cozimento, proteína e umidade não se observou diferença significativa ( $\mathrm{p}<0,05)$ com o decorrer do tempo. Kannan et al. (1997) e Meek et al. (2000), encontraram para perda de peso por cozimento, menores valores de 16,78 e $20,5 \%$, respectivamente; e maiores valores de $29,43 \%$ foram reportados por Allen et al. (1998), sendo que o resultado da pesquisa para o frango alternativo encontra-se na média dos dados da literatura. As porcentagens de proteína desta pesquisa foram similares aos reportados por Allen et al. (1998), Wattarachant et al. (2004) e Williams \& Damron (1998b) que estão na faixa de 20,35 a 21,80 \% e menores aos dados apresentados por Florowski et al. (2002) e Qiao et al. (2002) de 23,1 e 23,27 \%, respectivamente. Enquanto, a porcentagem de umidade valores de 74,54 a 75,31 \% obtiveram-se por Qiao et al. (2002), Florowski et al. (2002), Wattarachant et al. (2004), Williams \& Damron (1998a) e Allen et al. (1998) de acordo aos valores encontrados na pesquisa. 


\subsubsection{Carne de coxa}

Na coxa (Tabela 12), observou-se que apenas o parâmetro valor a* (tonalidade de vermelho) apresentou-se crescente com o decorrer do tempo, mostrando que a carne de coxa de frango apresentou-se mais escura às 72 horas pós abate em relação às 5 horas. Os demais atributos não variaram significativamente com os diferentes períodos.

Castellini et al. (2002), encontraram valores baixos para $\mathrm{pH}$ de 6,02, CRA de 56,21 $\%$, e valores maiores para perda de peso por cozimento de $35,17 \%, 3,08 \mathrm{~kg} / \mathrm{cm}^{2}$ de força de cisalhamento, umidade de $77,32 \%$, proteína $19,38 \%$ e cor de 56,28, 5,84, e 5,83 para $\mathrm{L}^{*}, \mathrm{a}^{*} \mathrm{e} \mathrm{b}^{*}$, respectivamente, em frangos de criação orgânica. Florowski et al. (2002) analisaram a carne da coxa de frangos convencionais, e relataram valores médios

próximos ao encontrado no presente trabalho, como, $\mathrm{pH}$ de 6,3, 73,4 \% de umidade e 55 de valor de $\mathrm{L}^{*}$, entretanto esses autores encontraram um valor mais elevado de proteína $(19 \%)$, valor $\mathrm{a}^{*}(4,0)$ e valor $\mathrm{b}^{*}(3,3)$.

A carne de coxa apresentou um valor mais elevado de $\mathrm{pH}$ em relação ao peito, e conseqüentemente uma maior CRA. Em pH 5,0-5,1 tem-se o menor valor de CRA, atingindo-se o ponto isoelétrico das proteínas (actina 4,7 e miosina 5,4), portanto, quanto mais próximo desse pH menor será a CRA (Price \& Schwiegert, 1994).

\subsubsection{Carne de sobrecoxa}

Com o aumento das horas após o abate, observa-se na Tabela 13, um acréscimo nos parâmetros perda de peso, teor de proteína e valor $a^{*}$. Os valores de $b^{*}$ e CRA variaram com o tempo, sendo que este último decresceu após 24 horas. Não houve diferença entre os períodos para as análises de $\mathrm{pH}$, umidade e valor $\mathrm{L}^{*}$.

Novamente se observa o maior valor de $\mathrm{pH}$ e CRA em relação ao peito, porém semelhante à coxa, isso se deve às características das fibras vermelhas, que por possuírem metabolismo oxidativo, favorecem um $\mathrm{pH}$ alto e, conseqüentemente, alta CRA (Price \& Schwiegert, 1994). 
Tabela 12. Análises físico-químicas da carne de coxa

\begin{tabular}{|c|c|c|c|c|c|c|c|c|c|c|}
\hline Período & $\mathbf{N}$ & $\begin{array}{c}\text { Perda peso } \\
\text { cozimento } \\
(\%)\end{array}$ & $\mathbf{L}^{*}$ & $\begin{array}{l}\text { Cor } \\
a^{*}\end{array}$ & b* & $\mathbf{N}$ & pH & $\begin{array}{c}\text { CRA } \\
(\%)\end{array}$ & $\begin{array}{c}\text { Proteína } \\
(\%)\end{array}$ & $\begin{array}{c}\text { Umidade } \\
(\%)\end{array}$ \\
\hline $5 \mathrm{hs}$ & 24 & $26,0^{\mathrm{a}} \pm 4,8$ & $55,8^{\mathrm{a}} \pm 3,0$ & $0,3^{\mathrm{b}} \pm 0,7$ & $2,1^{\mathrm{a}} \pm 4,0$ & 9 & $6,3^{\mathrm{a}} \pm 0,2$ & $63,8^{\mathrm{a}} \pm 1,4$ & $16,7^{\mathrm{a}} \pm 1,2$ & $75,3^{\mathrm{a}} \pm 3,2$ \\
\hline 24 hs & 24 & $27,7^{\mathrm{a}} \pm 5,6$ & $54,3^{\mathrm{a}} \pm 4,6$ & $0,6^{\mathrm{ab}} \pm 1,0$ & $2,1^{a} \pm 2,9$ & 9 & $6,3^{\mathrm{a}} \pm 0,1$ & $64,0^{\mathrm{a}} \pm 2,5$ & $16,8^{\mathrm{a}} \pm 0,9$ & $76,2^{\mathrm{a}} \pm 1,7$ \\
\hline 48 hs & 24 & $28,8^{\mathrm{a}} \pm 3,7$ & $55,9^{\mathrm{a}} \pm 2,2$ & $0,9^{\mathrm{ab}} \pm 0,7$ & $0,4^{a} \pm 2,3$ & 9 & $6,2^{\mathrm{a}} \pm 0,2$ & $63,9^{a} \pm 2,5$ & $17,2^{\mathrm{a}} \pm 1,0$ & $76,7^{\mathrm{a}} \pm 0,7$ \\
\hline 72 hs & 24 & $28,2^{\mathrm{a}} \pm 3,0$ & $54,3^{\mathrm{a}} \pm 2,6$ & $1,0^{\mathrm{a}} \pm 0,9$ & $2,3^{\mathrm{a}} \pm 2,8$ & 9 & $6,3^{\mathrm{a}} \pm 0,2$ & $62,6^{\mathrm{a}} \pm 1,4$ & $17,7^{\mathrm{a}} \pm 0,5$ & $77,2^{\mathrm{a}} \pm 0,9$ \\
\hline$P r>F$ & & 0,1712 & 0,1434 & 0,0382 & 0,1416 & & 0,4925 & 0,4328 & 0,1121 & 0,2115 \\
\hline
\end{tabular}

$\mathrm{N}$ : número de amostras.

${ }^{\mathrm{a}, \mathrm{b}}$ médias dentro de cada coluna com letras diferentes são significativamente diferentes $(\mathrm{p}<0,05)$.

Tabela 13. Análises físico-químicas da carne de sobrecoxa

\begin{tabular}{|c|c|c|c|c|c|c|c|c|c|c|}
\hline Período & $\mathbf{N}$ & $\begin{array}{c}\text { Perda peso } \\
\text { cozimento } \\
(\%)\end{array}$ & $\mathbf{L}^{*}$ & $\begin{array}{l}\text { Cor } \\
a^{*}\end{array}$ & $\mathbf{b}^{*}$ & $\mathbf{N}$ & PH & $\begin{array}{c}\text { CRA } \\
(\%)\end{array}$ & $\begin{array}{c}\text { Proteína } \\
(\%)\end{array}$ & $\begin{array}{c}\text { Umidade } \\
(\%)\end{array}$ \\
\hline $5 \mathrm{hs}$ & 24 & $26,4^{b} \pm 3,6$ & $47,5^{\mathrm{a}} \pm 2,9$ & $1,5^{\mathrm{b}} \pm 1,1$ & $0,8^{\mathrm{b}} \pm 2,9$ & 9 & $6,1^{a} \pm 0,2$ & $64,0^{\mathrm{ab}} \pm 2,2$ & $16,8^{\mathrm{b}} \pm 1,2$ & $77,0^{\mathrm{a}} \pm 2,1$ \\
\hline 24 hs & 24 & $26,6^{\mathrm{b}} \pm 2,9$ & $45,8^{\mathrm{a}} \pm 3,9$ & $1,5^{\mathrm{b}} \pm 1,4$ & $2,7^{\mathrm{a}} \pm 2,9$ & 9 & $6,1^{a} \pm 0,2$ & $65,9^{\mathrm{a}} \pm 1,6$ & $16,8^{\mathrm{ab}} \pm 0,6$ & $76,4^{\mathrm{a}} \pm 0,7$ \\
\hline $48 \mathrm{hs}$ & 24 & $28,3^{\mathrm{ab}} \pm 3,4$ & $46,8^{\mathrm{a}} \pm 2,5$ & $2,7^{\mathrm{a}} \pm 0,9$ & $1,9^{\mathrm{ab}} \pm 1,4$ & 9 & $6,1^{\mathrm{a}} \pm 0,1$ & $64,8^{\mathrm{ab}} \pm 1,7$ & $17,8^{\mathrm{ab}} \pm 1,6$ & $76,9^{\mathrm{a}} \pm 0,8$ \\
\hline 72 hs & 24 & $29,4^{\mathrm{a}} \pm 3,3$ & $47,0^{\mathrm{a}} \pm 1,6$ & $2,5^{\mathrm{a}} \pm 0,8$ & $1,9^{\mathrm{ab}} \pm 1,3$ & 9 & $6,2^{\mathrm{a}} \pm 0,2$ & $62,6^{\mathrm{b}} \pm 1,5$ & $18,1^{\mathrm{a}} \pm 0,8$ & $76,9^{\mathrm{a}} \pm 0,7$ \\
\hline$P r>F$ & & 0,0068 & 0,2388 & $<0,0001$ & 0,0483 & & 0,8594 & 0,0036 & 0,0122 & 0,7610 \\
\hline
\end{tabular}

$\mathrm{N}$ : número de amostras.

${ }^{\mathrm{a}, \mathrm{b}}$ médias dentro de cada coluna com letras diferentes são significativamente diferentes $(\mathrm{p}<0,05)$. 
Wattarachant et al. (2004), encontraram menores valores para $L^{*}(32,53), a^{*}(0,45)$ e b* (2,53); e maiores valores de $\mathrm{L}^{*} 55,1$, $\mathrm{a}^{*}$ de 8,6 e b* de 17,0 foram apresentados por Kannan et al. (1997). O valor de $\mathrm{L}^{*}$ foi similar ao mostrado no trabalho para o frango alternativo (Tabela 13). As porcentagens de perdas de peso para sobrecoxa alternativa foram maiores aos da literatura de 16,35 e 15,74\% (Kannan et al., 1997 e Wattarachant et al., 2004). Assim, observaram-se menores valores de pH no trabalho em relação aos encontrados de Wattarachant et al. (2004) e Krannan et al. (1997) com valores de 6,62 e 6,43, respectivamente. As porcentagens de proteína de Wattarachant et al. (2004), Williams \& Damron (1998a,b) foram 19,08 a 20,52\%, no entanto, no trabalho o valor para sobrecoxa alternativa (Tabela 13) encontra-se abaixo destes valores. Williams \& Damron (1998a,b) Wattarachant et al. (2004) mostraram valores de 73,61 a 77,2\% para umidade similares aos do trabalho $(76,4$ a 77,0 \%).

\subsubsection{Análise sensorial}

Os resultados da análise sensorial dos frangos criados em sistema alternativo e convencional são apresentados nas Tabelas 14, 15 e 16. De maneira geral, os frangos alternativo e convencional não diferiram entre si e nem entre as horas após abate para os três cortes.

Tabela 14. Médias e significâncias $(\mathrm{p}<0,05)$ da análise sensorial da carne de peito

\begin{tabular}{cccccccc}
\hline & & & Alternativo & & \multicolumn{3}{c}{ Convencional } \\
Período & $\mathbf{N}$ & Maciez & Suculência & Sabor & Maciez & Suculência & Sabor \\
\hline $\mathbf{2 4} \mathbf{~ h}$ & 3 & $5,5^{\mathrm{aA}} \pm 2,2$ & $5,8^{\mathrm{aA}} \pm 2,0$ & $6,1^{\mathrm{aA}} \pm 2,1$ & $5,6^{\mathrm{ab}} \pm 1,7$ & $5,5^{\mathrm{aA}} \pm 1,7$ & $6,2^{\mathrm{a} A} \pm 1,8$ \\
$\mathbf{4 8} \mathbf{~ h}$ & 4 & $5,4^{\mathrm{aA}} \pm 1,9$ & $5,1^{\mathrm{aA}} \pm 1,7$ & $6,4^{\mathrm{aA}} \pm 1,9$ & $5,1^{\mathrm{bA}} \pm 1,7$ & $4,9^{\mathrm{aA}} \pm 1,9$ & $5,9^{\mathrm{a} A} \pm 2,0$ \\
$\mathbf{7 2} \mathbf{~ h}$ & 3 & $5,7^{\mathrm{aA}} \pm 1,9$ & $5,7^{\mathrm{aA}} \pm 1,7$ & $6,3^{\mathrm{aA}} \pm 1,9$ & $6,3^{\mathrm{aA}} \pm 1,6$ & $5,6^{\mathrm{aA}} \pm 1,7$ & $5,9^{\mathrm{aA}} \pm 2,0$ \\
\hline
\end{tabular}

N: número de amostras.

$\mathrm{a}^{\mathrm{a}}$ Indicam comparação entre os períodos.

${ }^{\mathrm{AB}}$ Indicam comparação entre os frangos. 
Para o peito (Tabela 14), somente foi observada diferença entre os períodos para o atributo maciez do frango convencional. Quanto à coxa, observa-se na Tabela 15, uma diferença significativa entre os frangos às $72 \mathrm{~h}$, onde o frango alternativo mostrou-se mais macio que o convencional.

Tabela 15. Médias e significâncias $(\mathrm{p}<0,05)$ da análise sensorial da carne de coxa

\begin{tabular}{cccccccc}
\hline & & \multicolumn{3}{c}{ Alternativo } & \multicolumn{3}{c}{ Convencional } \\
Período & $\mathbf{N}$ & Maciez & Suculência & Sabor & Maciez & Suculência & Sabor \\
\hline $\mathbf{2 4} \mathbf{~ h}$ & 3 & $7,2^{\mathrm{aA}} \pm 1,1$ & $6,9^{\mathrm{aA}} \pm 1,4$ & $6,7^{\mathrm{aA}} \pm 1,9$ & $6,7^{\mathrm{aA}} \pm 1,6$ & $6,3^{\mathrm{aA}} \pm 1,8$ & $6,6^{\mathrm{aA}} \pm 1,7$ \\
$\mathbf{4 8} \mathbf{~ h}$ & 4 & $6,9^{\mathrm{aA}} \pm 1,6$ & $6,3^{\mathrm{aA}} \pm 1,7$ & $6,9^{\mathrm{aA}} \pm 1,5$ & $7,0^{\mathrm{aA}} \pm 1,3$ & $6,4^{\mathrm{aA}} \pm 1,5$ & $6,7^{\mathrm{aA}} \pm 1,6$ \\
$\mathbf{7 2} \mathbf{~ h}$ & 3 & $7,3^{\mathrm{aA}} \pm 1,4$ & $6,7^{\mathrm{aA}} \pm 1,6$ & $6,7^{\mathrm{aA}} \pm 1,9$ & $6,5^{\mathrm{a} \mathrm{B}} \pm 1,4$ & $6,2^{\mathrm{aA}} \pm 1,4$ & $6,5^{\mathrm{aA}} \pm 1,6$ \\
\hline
\end{tabular}

$\mathrm{N}$ : número de amostras.

${ }^{\mathrm{a}}$ Indicam comparação entre os períodos.

${ }^{\mathrm{AB}}$ Indicam comparação entre os frangos.

Os tipos de criação de frangos apresentaram-se sensorialmente diferentes em relação ao atributo maciez nos períodos de 24 e 72 horas após abate em relação à sobrecoxa (Tabela 16).

Tabela 16. Médias e significâncias $(\mathrm{p}<0,05)$ da análise sensorial da carne de sobrecoxa

\begin{tabular}{cccccccc}
\hline & & \multicolumn{3}{c}{ Alternativo } & \multicolumn{3}{c}{ Convencional } \\
Período & $\mathbf{N}$ & Maciez & Suculência & Sabor & Maciez & Suculência & Sabor \\
\hline $\mathbf{2 4} \mathbf{~ h}$ & 3 & $7,6^{\mathrm{aA}} \pm 1,1$ & $6,9^{\mathrm{aA}} \pm 1,5$ & $6,8^{\mathrm{aA}} \pm 1,5$ & $6,6^{\mathrm{a} \mathrm{B}} \pm 1,5$ & $6,2^{\mathrm{aA}} \pm 1,5$ & $6,6^{\mathrm{aA}} \pm 1,6$ \\
$\mathbf{4 8} \mathbf{~ h}$ & 4 & $7,4^{\mathrm{aA}} \pm 1,4$ & $6,7^{\mathrm{aA}} \pm 1,6$ & $6,7^{\mathrm{aA}} \pm 1,8$ & $7,1^{\mathrm{aA}} \pm 1,5$ & $6,7^{\mathrm{aA}} \pm 1,5$ & $6,7^{\mathrm{aA}} \pm 1,6$ \\
$\mathbf{7 2} \mathbf{~ h}$ & 3 & $7,0^{\mathrm{aA}} \pm 1,4$ & $6,5^{\mathrm{aA}} \pm 1,3$ & $6,7^{\mathrm{aA}} \pm 1,5$ & $6,4^{\mathrm{a}} \pm 1,3$ & $6,0^{\mathrm{aA}} \pm 1,5$ & $6,8^{\mathrm{aA}} \pm 1,6$ \\
\hline
\end{tabular}

$\mathrm{N}$ : número de amostras.

${ }^{\mathrm{a}}$ Indicam comparação entre os períodos.

${ }^{\mathrm{AB}}$ Indicam comparação entre os frangos. 
Castellini et al. (2002), utilizando escala estruturada de cinco pontos na avaliação sensorial, encontraram maior significância para o atributo suculência $(3,7$ e 3,3; p < $0,05)$ e aceitação global $(3,5$ e 3,0, p < 0,05) para os músculos de peito de criação orgânica, comparados ao convencional. O sabor está associado a componentes que estão contidos na fração solúvel - água de tecido do músculo de peito (Judge et al., 1989).

Williams \& Damrom (1998a), obtiveram valores de suculência (4,77 e 5,91), maciez $(6,67$ e 6,54) e sabor $(5,49$ e 6,47) para carne de peito e sobrecoxa respectivamente. Os provadores não encontraram diferença significativa no sabor e na suculência de peito e coxa de frango nos diferentes tratamentos de dietas. No trabalho concorda-se com estes resultados, pois não encontraram diferenças entre os frangos de criação alternativa e convencional. Nas diferenças encontradas entre cortes de peito e sobrecoxa, a maior diferença observada foi determinada pelas características sensoriais, principalmente devido ao tipo de músculo, pois a carne de sobrecoxa tem maior quantidade de gordura que a carne de peito (Stadelman et al., 1989). Alguns dos componentes da ave, como a gordura solúvel é maior na sobrecoxa que no peito (Lindsay, 1985). Portanto, a presença de gordura contribui para a suculência do músculo (Willians \& Damrom, 1998b).

\subsubsection{Relação entre atributos de qualidade e análise sensorial}

A análise de correlação simples de Pearson foi realizada entre os atributos físicoquímicos e sensoriais, e os resultados significativos de peito, coxa e sobrecoxa encontram-se na Tabela 17, 18 e 19, respectivamente.

Observa-se na Tabela 17, que os atributos sensoriais maciez e suculência do peito de frango estão inversamente correlacionados com os parâmetros perda de peso e valor L*, ou seja, quanto mais macia e suculenta for uma carne de peito, menor será a perda de peso por cozimento e menos pálida será a sua cor. A perda de peso também está correlacionada inversamente com o valor $b^{*}$ e diretamente com o valor $a^{*}$. A diferença dos resultados obtidos por Barbut, (1993); Yang e Chen (1993), Fletcher (1995) e Allen et al. (1997, 1998), mostraram correlação inversa significativa entre o valor de L* e o 
pH da carne de peito; não foi observada correlação entre a umidade e o valor de $\mathrm{L}^{*}$. Carne com menor $\mathrm{pH}$ foi associada com uma menor CRA, porém com maior perda de peso por cozimento e gotejamento (Froning et al., 1978, Barbut, 1993 e Northcutt et al., 1994). Portanto, um menor valor de pH apresenta redução da maciez (Froning et al, 1978, Barbut, 1993) e aumento na vida de prateleira (Allen et al., 1997).

Tabela 17. Análise de correlação simples de Pearson para a carne de peito

\begin{tabular}{llcc}
\hline & Parâmetros & Correlação & Significância \\
\hline Maciez & Perda de peso & $-0,34^{*}$ & 0,013 \\
Maciez & Valor L* & $-0,37^{* *}$ & 0,006 \\
Suculência & Força cisalhamento & $-0,28^{*}$ & 0,044 \\
Suculência & Valor L* & $-0,31^{*}$ & 0,023 \\
Suculência & Perda de peso & $-0,28^{*}$ & 0,034 \\
Perda de peso & Valor a* & 0,046 \\
Perda de peso & Valor $b^{*}$ & $0,24^{*}$ & 0,048 \\
\hline$* \mathrm{p}<0,05 ; * \mathrm{p}<0,01$ & $-0,23^{*}$ &
\end{tabular}

A correlação de maciez e valor de L* para o peito alternativo no trabalho concorda com o resultado de Barbut (1996) e Mc Curdy et al. (1996), porém estes autores também encontraram correlação do valor de L* com a perda de peso. No entanto, Florowski et al. (2002), encontraram correlação inversa entre valor de L* com proteína e pH e correlação positiva com a CRA; a correlação do valor de $\mathrm{L}^{*}$ e CRA indicaram que o pH do músculo de peito maturado poderia ser utilizado como uma medida para estimação do valor tecnológico da carne (Florowski et al., 2002); correlações estas não encontradas no peito de frango alternativo do presente trabalho (Tabela 17).

Lyon \& Lyon (1997), reportaram que a suculência não foi correlacionada com a maciez instrumental, além disso, a diferença da maciez instrumental não foi percebida pela equipe de provadores (Meek et al., 2000) concordando com o observado para peito de frango de criação alternativa. 
Simpson \& Goodwin (1974) e Lyon \& Lyon (1990b), relacionaram a maciez objetiva com a avaliação sensorial e encontram que os valores de cisalhamento no limite da maciez aceitável para carne de peito de frango são 8,0 ou 8,8 kg/g de amostra, respectivamente. Portanto, isso indica que a carne de peito alternativo do trabalho pode ser considerada como macia (5,4 a 5,7 para avaliação sensorial e de 8,2 a 3,0 kgf.cm ${ }^{2}$ para a força de cisalhamento).

Segundo Liu et al. (2004), existem correlações entre pH, mudança de cor, perda de peso por cozimento, força de cisalhamento e atributos sensoriais. A cor não está correlacionada diretamente com a textura e sabor, porém é importante no aspecto visual da carne antes da ingestão. A força de cisalhamento tem correlação positiva com os atributos sensoriais como maciez, no entanto não tem correlação com o sabor; resultados diferentes dos obtidos no trabalho, no qual a força de cisalhamento e perda de peso tem correlação inversa com a suculência e não com a maciez, o valor de $\mathrm{L}^{*}$ correlaciona-se inversamente com a maciez e suculência.

Em relação à coxa (Tabela 18), a correlação encontrada, entre os parâmetros, suculência e perda de peso, foi direta, ao contrário daquela observada no peito. Tal fato pode ser explicado pela maior porcentagem de gordura encontrada na coxa, sendo um dos fatores responsáveis pela sensação de suculência. Porém, a gordura também ocasiona uma maior perda de peso, uma vez que ela se desprende da carne durante o cozimento. Pode-se notar ainda, que a perda de peso da coxa está correlacionada diretamente com o teor de proteína e inversamente a CRA, parâmetros esses, diferentes dos encontrados no peito. Resultado estes não similares aos obtidos por Florowski et al. (2002), onde foi observada correlação inversa do valor de $\mathrm{L}^{*}$ com proteína e positiva do valor de $\mathrm{L}^{*}$ com CRA, para carne de coxa. 
Tabela 18. Análise de correlação simples Pearson para a carne de coxa

\begin{tabular}{llcc}
\hline & Parâmetros & Correlação & Significância \\
\hline Suculência & $\mathrm{pH}$ & $-0,25^{*}$ & 0,038 \\
Suculência & Perda de peso & $0,32^{*}$ & 0,018 \\
Perda de peso & CRA & $-0,40^{* *}$ & 0,001 \\
Perda de peso & Proteína & $0,35^{* *}$ & 0,003 \\
PH & Proteína & $-0,25^{*}$ & 0,038 \\
\hline
\end{tabular}

$* \mathrm{p}<0,05 ; * * \mathrm{p}<0,01$

Não foi encontrada nenhuma correlação entre os parâmetros físico-químicos e sensoriais para a sobrecoxa (Tabela 19). Entretanto, observou-se que o teor de proteína mostrou ser um parâmetro importante para a análise deste corte cárneo, pois está correlacionado diretamente com a perda de peso e o valor $\mathrm{a}^{*}$, e inversamente com a CRA e o teor de umidade. Estes resultados discordam com os obtidos por Wattarachant et al. (2004), onde o pH do músculo e a cor de carne são altamente correlacionadas.

Tabela 19. Análise de correlação simples de Pearson para a carne de sobrecoxa

\begin{tabular}{lccc}
\hline & Parâmetros & Correlação & Significância \\
\hline Perda de peso & Valor a* $^{*}$ & $0,33^{* *}$ & 0,005 \\
Proteína & Valor a* $^{*}$ & $0,27^{*}$ & 0,024 \\
Proteína & Perda de peso & $0,24^{*}$ & 0,047 \\
Proteína & Umidade & $-0,25^{*}$ & 0,035 \\
Proteína & CRA & $-0,32^{*}$ & 0,006 \\
\hline
\end{tabular}

$* \mathrm{p}<0,05 ; * \mathrm{p}<0,01$

As figuras 9, 10 e 11 apresentam os resultados da análise de correspondência realizada com os resultados das análises físico-químicas de peito, coxa e sobrecoxa, respectivamente. Esta análise distribui os dados em duas dimensões, de acordo com a distância entre eles. 
$\mathrm{Na}$ análise de peito (Figura 9), as duas dimensões são responsáveis por $100 \%$ de explicação, onde, o período de 5 horas foi mais caracterizado pelo elevado valor da força de cisalhamento e valor de $b^{*}$, o qual também caracterizou às 24 horas pós abate; às 48 horas foi representada pelo CRA e perda de peso por cozimento, e às 72 horas, pelo teor de umidade. O valor $\mathrm{L}$ foi compartilhado pelos períodos de 48 e 72 horas, e os parâmetros valor $\mathrm{a}^{*}, \mathrm{pH}$ e teor de proteína, localizada no centro do gráfico, não se destacaram em nenhum período. Observa-se ainda, a proximidade dos períodos 5 e 24 horas, indicando uma semelhança na qualidade global da carne nesses períodos, diferindo dos demais.

Na figura 10, observa-se para a coxa, que 72 horas pós-abate foi caracterizada pelos atributos perda de peso, valor $\mathrm{a}^{*}$, teor de proteína e umidade, porém este modelo alcançou apenas $86 \%$ de explicação pelas duas dimensões.

Na Figura 11, o período de 5 horas da sobrecoxa foi caracterizado pela umidade e valor $\mathrm{L}$, enquanto o de 24 horas foi o $\mathrm{pH}$. $\mathrm{O}$ valor a* apresentou a maior média às 48 horas e a perda de peso, às 72 horas, enquanto que o teor de proteína se destacou em ambos (48 e 72 horas). 


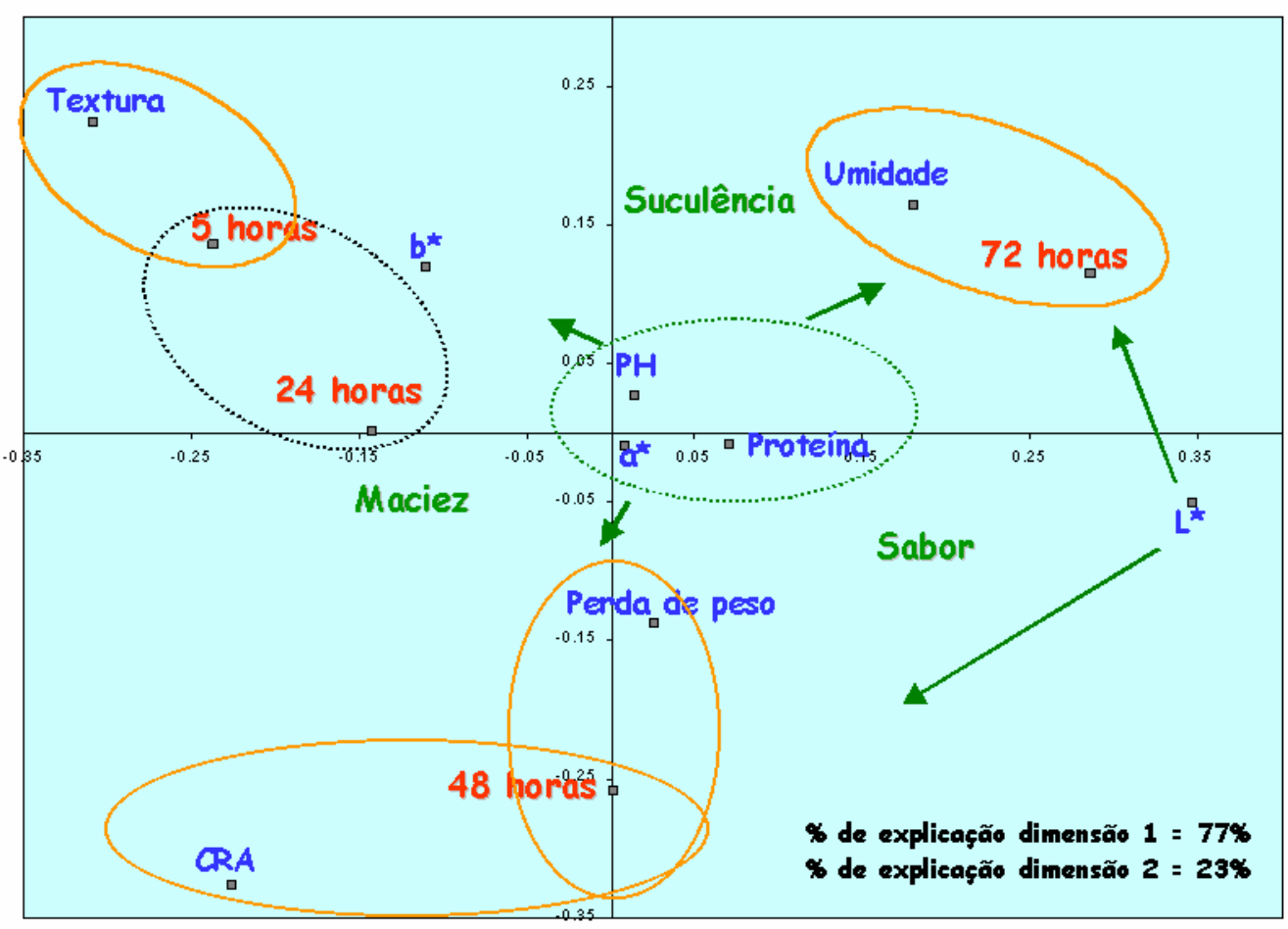

Figura 9 - Análise de correspondência para carne de peito

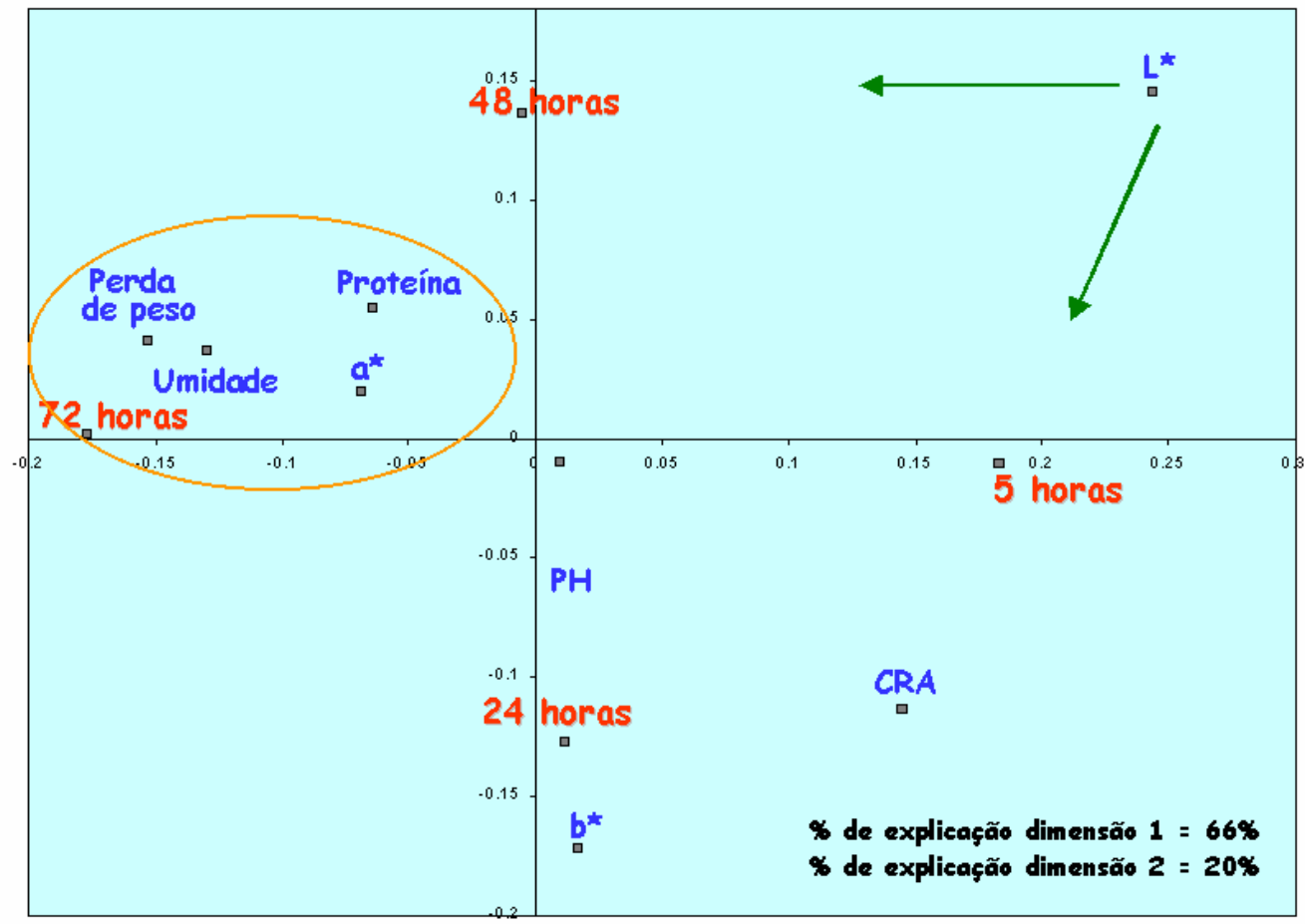

Figura 10 - Análise de correspondência para carne de coxa 


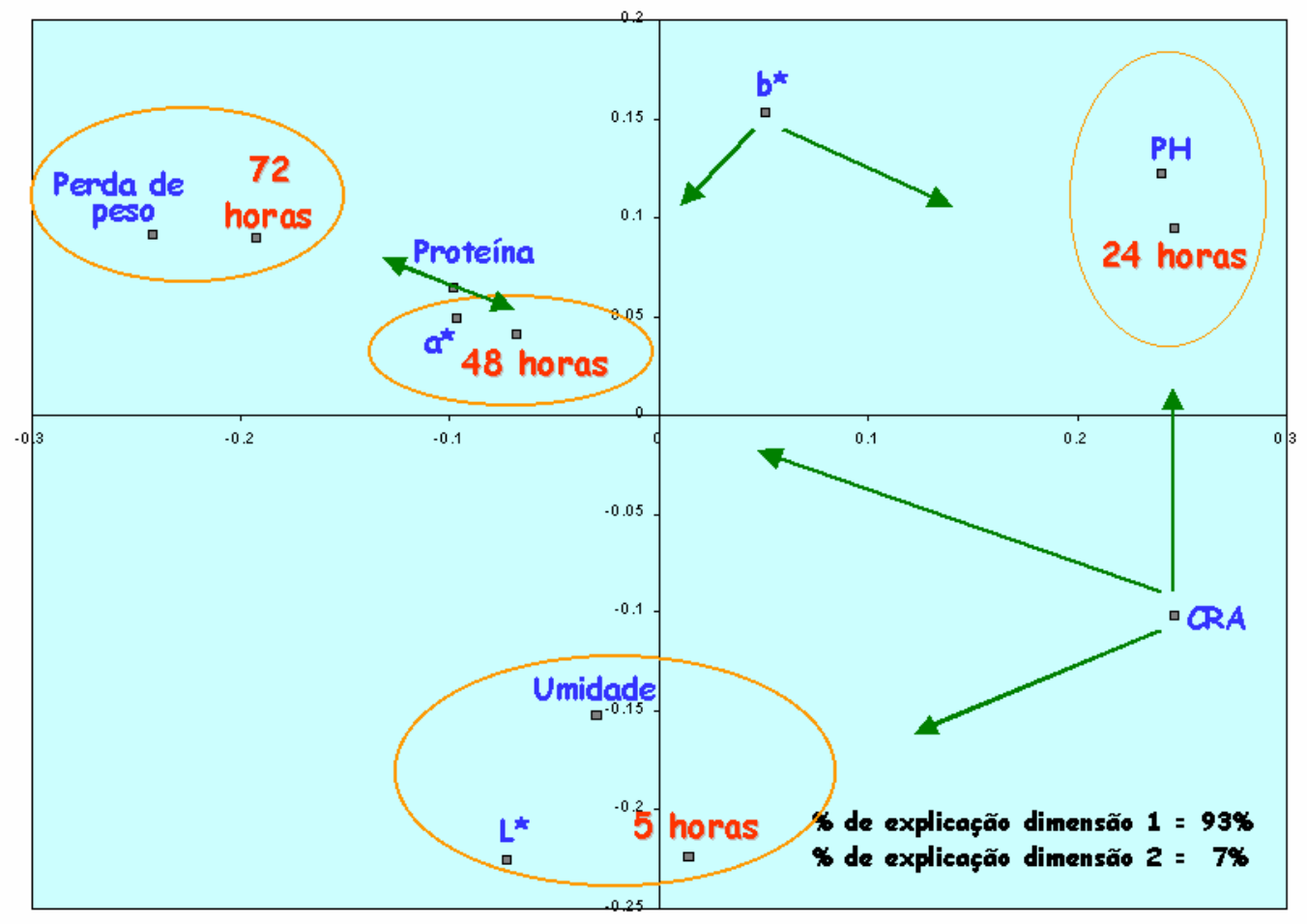

Figura 11 - Análise de correspondência para carne de sobrecoxa

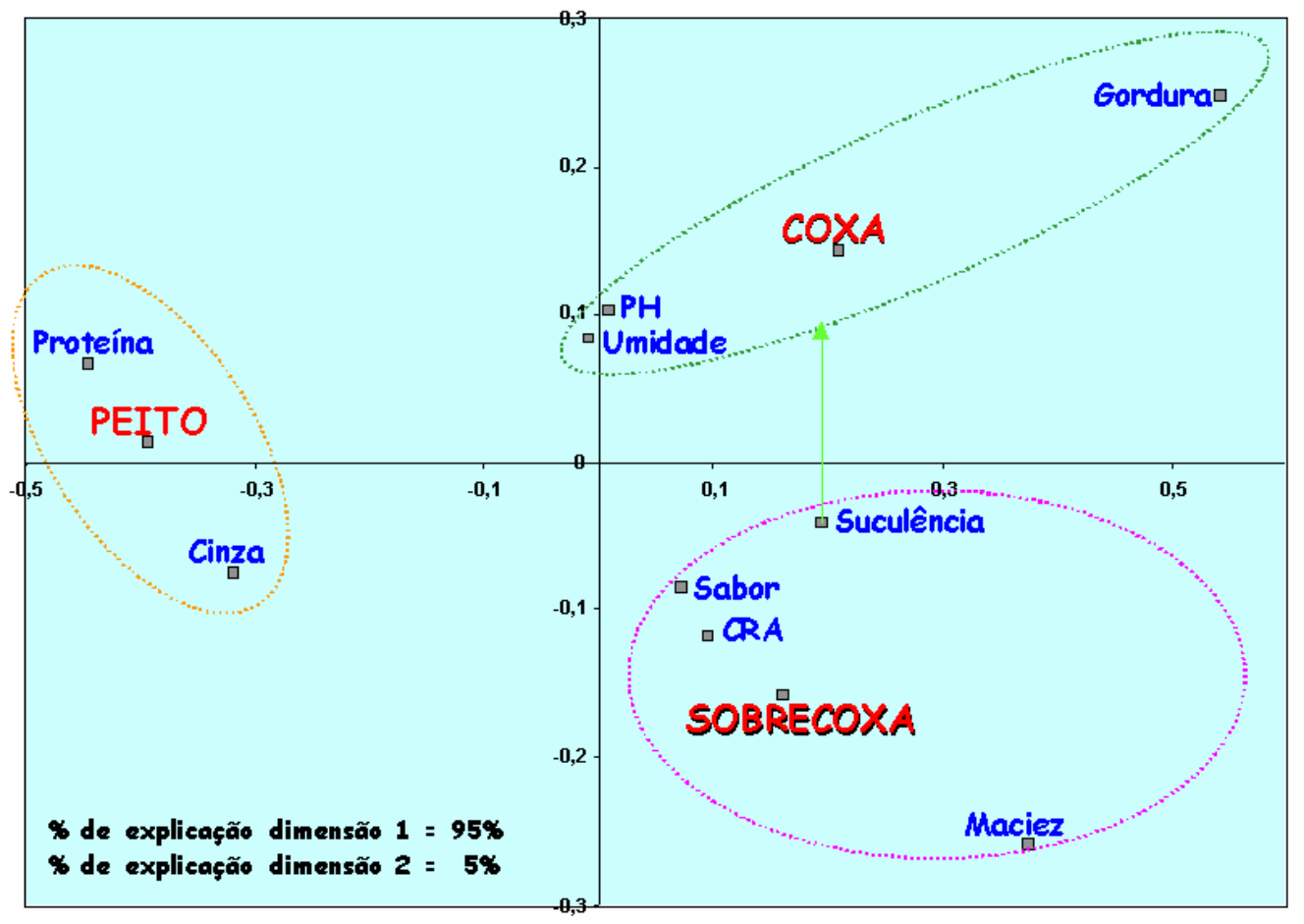

Figura 12 - Análise de Correspondência das análises de carne de peito, sobrecoxa e coxa 
Tabela 20. Valores médios das análises físico-químicas e sensoriais dos cortes de carne de frango $(\mathrm{p}<0,05)$

\begin{tabular}{|c|c|c|c|c|c|c|c|c|c|}
\hline & $\begin{array}{c}\text { Proteína } \\
\text { (\%) }\end{array}$ & $\begin{array}{c}\text { Umidade } \\
\text { (\%) }\end{array}$ & $\begin{array}{c}\text { Gordura } \\
\text { (\%) }\end{array}$ & $\begin{array}{c}\text { Cinza } \\
(\%)\end{array}$ & $\begin{array}{l}\text { CRA } \\
(\%)\end{array}$ & pH & Maciez & Suculência & Sabor \\
\hline Peito & $20,1^{\mathrm{a}}$ & $75,4^{a}$ & $1,6^{b}$ & $1,12^{\mathrm{a}}$ & $57,5^{b}$ & $5,8^{b}$ & $5,5^{b}$ & $5,8^{b}$ & $6,1^{a}$ \\
\hline Sobrecoxa & $16,8^{b}$ & $75,3^{a}$ & $4,4^{\mathrm{a}}$ & $1,02^{b}$ & $65,9^{a}$ & $6,1^{\mathrm{a}}$ & $7,6^{\mathrm{a}}$ & $6,9^{\mathrm{a}}$ & $6,8^{a}$ \\
\hline Coxa & $16,7^{\mathrm{b}}$ & $77,0^{\mathrm{a}}$ & $5,2^{\mathrm{a}}$ & $0,98^{b}$ & $64,0^{\mathrm{a}}$ & $6,3^{\mathrm{a}}$ & $7,2^{\mathrm{a}}$ & $6,9^{\mathrm{a}}$ & $6,7^{\mathrm{a}}$ \\
\hline Valor F & $19,69^{*}$ & 1,56 n.s. & $7,46^{*}$ & $22,79 *$ & $35,88 *$ & $21,89 *$ & $19,76^{*}$ & $6,09 *$ & 1,83 n.s. \\
\hline $\operatorname{Pr}>F$ & $<0,0001$ & 0,2305 & 0,0030 & $<0,0001$ & $<0,0001$ & $<0,0001$ & $<0,0001$ & 0,0031 & 0,1644 \\
\hline
\end{tabular}

a, b médias dentro de cada coluna com letras diferentes são significativamente diferentes $(\mathrm{p}<0,05)$. 
Observando a Tabela 20, verifica-se que o peito de frango diferiu significativamente $(\mathrm{p}<0,05)$ dos cortes de coxa e sobrecoxa em relação à maioria dos atributos analisados. $\mathrm{O}$ peito apresentou maior teor de proteína e cinza e menor $\mathrm{pH}$, CRA, suculência, maciez e teor de gordura em relação à coxa e sobrecoxa.

$\mathrm{Na}$ análise de correspondência dos cortes de peito, coxa e sobrecoxa, observa-se na Figura 12, que as duas dimensões do gráfico são responsáveis por $100 \%$ de explicação, sendo que $95 \%$ é devida a dimensão 1, onde as variáveis teor de proteína e gordura estão localizados de maneira oposta, assim esta dimensão está indicando teor de gordura. Portanto, pode-se considerar que estes dois atributos são os maiores responsáveis pelas diferenças entre o peito e os demais cortes (coxa e sobrecoxa). Pode-se ainda, ressaltar que na dimensão 1 a coxa e sobrecoxa encontram-se próximas entre si e distantes do peito, como esperado, pois coxa e sobrecoxa apresentam características sensoriais e físico-químicas similares. Notou-se, também, que a sobrecoxa destacou-se sensorialmente dos demais cortes, pois os três atributos sensoriais (maciez, suculência e sabor) ficaram agrupados com a sobrecoxa.

Os dados das análises sensoriais dos frangos alternativo e convencional foram submetidos à análise de regressão múltipla. Os modelos finais são apresentados a seguir:

MACIEZ $_{\text {Alt. } \text { PEITO }}=1,057+0,538 \times$ SUCULÊNCIA $+0,242 \times$ SABOR

MACIEZ $_{\text {Alt. COXA }}=3,142+0,477 \times$ SUCULÊNCIA $+0,124 \times$ SABOR

MACIEZ $_{\text {Alt. SOBRECOXA }}=3,759+0,538 \times$ SUCULÊNCIA

MACIEZ $_{\text {Conv. } \text { PEITO }}=3,114+0,5538 \times$ SUCULÊNCIA 
MACIEZ $_{\text {Conv. COXA }}=2,897+0,570 \times$ SUCULÊNCIA

MACIEZ $_{\text {Conv. SOBRECOXA }}=3,163+0,584 \times$ SUCULÊNCIA

Pode-se observar, que no peito a influência da suculência é duas vezes maior que a do sabor sobre a maciez. Na coxa, a suculência tem um efeito altamente significativo na maciez, porém a variável sabor só é significativo a um nível de significância de $8 \%$. Entretanto, não se observa o efeito do sabor sobre a maciez na sobrecoxa, influenciada somente pela suculência.

Em todos os cortes do frango convencional, a maciez sofre apenas o efeito da suculência. Além disso, nota-se que os modelos para peito, coxa e sobrecoxa, deste tipo de frango, foram bem semelhantes.

A suculência e dureza esta intimamente relacionadas, a menor dureza mais rapidamente são libertados os sucos ao mastigar e parece mais suculento (Price \& Schwiegert, 1994). A suculência não foi grandemente correlacionada com outro atributo sensorial. Embora a suculência seja um componente da textura, ela também é considerada um importante atributo de qualidade da carne cozida, pois sua relação com a textura tem importância na aceitabilidade da textura, portanto, a maciez sensorial e aceitabilidade da textura foram correlacionadas com a medição objetiva (Lyon \& Lyon, 1990a). 


\section{CONCLUSÕES}

- Na aplicação do sistema de classificação o maior defeito encontrado foi a presença de hematomas nas carcaças e cortes de peito, coxa e sobrecoxa de frango.

- Segundo a análise discriminante, a variável hematoma mostra uma predição aceitável, o que indica que pode ser utilizada para a classificação de carcaças $(84,9 \%)$ e cortes de peito $(87,7 \%)$, coxa $(96,2 \%)$ e sobrecoxa $(95,0 \%)$.

- Segundo o CRA foi comprovado que como variável de classificação tem muita variação e segundo a análise discriminante (43,1\% para coxa) não pode ser utilizada para classificar, apesar de existir diferença significativa entre as classes.

- Os resultados físico-químicos de peito mostraram a alta qualidade da carne do tipo de criação alternativa de frango, apresentando baixa força de cisalhamento (alta maciez), alta CRA e baixa perda de peso por cozimento.

- A coxa apresentou pouca variação nos parâmetros físico-químicos e sensoriais durante os períodos após abate. Por possuir alta proporção de fibras vermelhas, apresentou valores de $\mathrm{pH}$ e CRA mais altos que os de peito. E, devido ao alto teor de gordura, apresentou correlação positiva entre suculência e a perda de peso por cozimento.

- As principais mudanças, após abate, observadas na sobrecoxa foram os acréscimos na perda de peso por cozimento, no teor de proteína e no valor de $\mathrm{a}^{*}$. O teor de proteína foi o parâmetro que apresentou o maior número de correlações com os demais atributos. 
- A equipe de provadores não encontrou diferença sensorial entre o peito de frango alternativo e convencional. A maciez está relacionada à suculência e o sabor para o frango alternativo.

- O resultado sensorial para coxa e sobrecoxa indicou que existe diferença entre o frango alternativo e convencional enquanto ao atributo maciez. Na coxa alternativa observa relação de maciez com a suculência e o sabor. Porém, para coxa de frango alternativo e os cortes de frango convencional a maciez só foi relacionada com a suculência. 


\section{REFERÊNCIAS BIBLIOGRÁFICAS}

ABENI, F.; BERGOGLIO, G. Characterization of different strains of broiler chicken by carcass measurements, chemical and physical parameters and NIRS on breast muscle. Meat Science, v.57, n.2, p.133-137, 2001.

ALLEN, C.D.; RUSSELL, S.M.; FLETCHER, D.L. The relationship of broiler breast meat color and $\mathrm{pH}$ to shelf-life and color development. Poultry Science, v.76, n.7, p.1042-1046, 1997.

ALLEN, C.D.; FLETCHER, D.L.; NORTHCUTT, J.K; RUSSEL, S.M. The relationship of broiler breast color to meat quality and self-life. Poultry Science, v.77, n.2, p.361-366, 1998.

ANG, C.Y.W.; HAMM, D. Influence of length of feed withdrawal times on proximate composition and levels of selected vitamins and minerals in broiler breast meat. Poultry Science, v.64, n.8, p.1491-1493, 1985.

ANG, C.Y.W.; LUI, F. Influence of heating endpoint temperature on volatiles from poultry meat - a review. Journal of Muscle Food, v.7, n.4, p.291-302, 1996.

ASSOCIAÇÃO BRASILEIRA DE EXPORTAÇÃO DE FRANGO. Produção e exportação de frango. http://www.abef.com.br (10 set. 2004)

ASSOCIATION OF OFFICIAL ANALYTICAL CHEMISTRYS. Official methods analysis of the Association of Official Chemistry. 16.ed. Washington, 1998. 2v.

BARBUT, S. Poultry products processing. Boca Raton: CRC Press, 2002. 543p. 
BARBUT, S. Estimating the magnitude of the PSE problem in poultry. Journal of Muscle Food, v.9, n.1, p.35-49, 1998.

BARBUT, S. Estimates and detection of the PSE problem in young turkey breast meat. Canadian Journal of Animal Science, v.76, n.3, p.455-457, 1996.

BARBUT, S. Methods of testing protein functionally. London: Chapman \& Hall, 1996. p.187-225: Water and fat holding.

BARBUT, S. Color measurement for evaluating the pale soft exudative (PSE) occurrence in turkey meat. Food Research International, v.26, n.1, p.39-43, 1993.

BARTOV, I. Effect of feed withdrawal on yield, fat content, and fatty acid composition of liver fat in broilers. In: WORLD'S POULTRY CONGRESS, 19., Amsterdam, 1992. Proceedings. Amsterdam: s.ed., 1992. v.3, p.195-199.

BAYLISS, P.A.; HINTON, M.H. Transportation of broilers with special reference to mortality rates. Applied Animal Behavior Science, v.28, n.1, p.93-118, 1990.

BENDALL, J.R. Post-mortem changes in muscle. In: BOURNE, G.A. Structure and function of muscle. New York: Academic Press, 1973. p.243-309.

BERRI, C.; WACRENIER, N.; MILLET, N.; LE BIHAN-DUVAL, E. Effect the selection for improved body composition on muscle and meat characteristics broilers from experimental and commercial lines. Poultry Science, v.80, n.7, p.833-838, 2001 .

BINGHAM, A.N. Automation of broiler harvest. Poultry International, v.25, n.1, p.4142, 1986.

BOULIANNE, M.; KING, A.J. Biochemical and color characteristics of skinless boneless pale chicken breast meat. Poultry Science, v.74, n.10, p.1693-1698, 1995.

BOULIANNE, M.; KING, A.J. Meat color and biochemical characteristics of unaccepted dark-colored broiler chicken carcasses. Journal of Food Science, v.63, n.5, p.759-762, 1998. 
BOURNE, C.B. Food texture and viscosity: concept and measurement. New York: Academic Press, 1982. 325p.

BRASIL. Ministério da Agricultura, Pecuária e Abastecimento: Departamento de inspeção de produtos de origem animal. Portaria $\mathbf{n}^{\circ}$ 210, 10/11/1998. http://agricultura.gov.br/das/dipoa (10 dez. 2003)

BRASIL. Ministério da Agricultura, Pecuária e Abastecimento: Departamento de inspeção de produtos de origem animal. Portaria $\mathbf{n}^{\circ}$ 007, 19/05/1999. http://agricultura.gov.br/das/dipoa (10 dez. 2003)

BRESSAN, C. Efeito dos fatores pre-abate sobre a qualidade do peito de frango. Campinas, 1998. 179p. Tese (Doutorado) - Faculdade de Engenharia de Alimentos, Universidade Estadual de Campinas.

BYRNE, D.V.; O`SULLIVAN, M.G.; DIJKSTERHUIS, G.; BREDIE, W.L.P.; MARTENS, M. Sensory panel consistency during development of a vocabulary for warmed-over flavour. Food Quality and Preference, v.12, n.3, p.171-187, 2001.

CARLYLE, W.H.; GUISE, H.J.; COOK, P. Effect of time farm loading and processing on carcasses quality of broiler chickens. Veterinary Record, v.141, n.14, p.364-372, 1997.

CASTELLINI, C.; MUGNAI, C.; DAL BOSCO, A. Effect of organic production system on broiler carcass and meat quality. Meat Science, v.60, n.3, p.219-225, 2002.

CONTRERAS, C.C. Efeitos do atordoamento elétrico, estimulação elétrica e da desossa à quente na qualidade da carne do peito de frango "Pectoralis major". Campinas, 1995. 150p. Tese (Doutorado) - Faculdade de Engenharia de Alimentos, Universidade Estadual de Campinas.

CONTRERAS, C.C.; BERAQUET, N.J. Electrical stunning, hot boning and quality of chicken breast meat. Poultry Science, v.80, n.4, p.501-507, 2001. 
CONTRERAS, C.C.; CUSTODIO, C.V. Atributos de qualidade em carcaças de frangos: vale a pena avaliara em nível de produção industrial. In: CONFERENCIA APINCO DE CIÊNCIA E TECNOLOGIA AVÍCOLAS, Campinas, 2002. Anais. Campinas: FACTA, 2002. p.31-45.

DAWSON, P.L.; JANKY, D.M.; DUKES, M.G.; THOMPSON, L.D.; WOODWARD, S.A. Effect of post-mortem boning time during simulated commercial processing on the tenderness of broiler breast meat. Poultry Science, v.66, n.8, p.1331-1333, 1987.

DEMATTÊ FILHO, L.C.; MENDES, C.M.I. Viabilidade técnica e econômica na criação alternativa de frangos. In: CONFERENCIA APINCO DE CIÊNCIA E TECNOLOGIA AVÍCOLAS, Campinas, 2001. Anais. Campinas: FACTA, 2001. p. $255-266$.

EKSTRAND, C. An observational cohort study of the effects of catching method on carcass rejection rates in broiler. Animal Welfare, v.7, n.1, p.87-96, 1998.

ESTADOS UNIDOS. Department of Agriculture. Classes, standards and grades for poultry $\mathbf{N}^{\circ} \mathbf{7 0 , 2 0 0}$. Washington, 2002. 24p.

ESTADOS UNIDOS. Department of Agriculture. Poultry grading manual $\mathbf{N}^{\mathbf{0}} \mathbf{3 1}$. Washington, 1999. 31p.

FARMER, L.J. Poultry meat flavour. In: POULTRY MEAT SCIENCE SYMPOSIUM, Oxfordhine, 1999. Proceedings. Oxfordhine: CABI Publ., 1999. 1v.

FARSAIE, A.; CARR, L.E.; WABECK, C. Mechanical harvest of broilers. Transactions of the ASAE, v.26, n.6, p.1650-1653, 1983.

FERNANDEZ, X.; FORSLID, A.; TORNBERG, E. The effect of high post-mortem temperature on the development of pale, soft and exudative pork: interaction with ultimate pH. Meat Science, v.37, n.1, p.133-147, 1994.

FLETCHER, D.L. Relationship of breast meat colour variation to muscle $\mathrm{pH}$ and texture. Poultry Science, v.74, p.120S, 1995. Supplement 1. /Apresentado ao 84. Annual Meeting, Edmonton, 1995 - Abstracts/ 
FLETCHER, D.L.; Broiler breast meat color variation, $\mathrm{pH}$ and texture. Poultry Science, v.78, n.9, p.1323-1327, 1999.

FLOROWSKI, T.; SLOWINSKI, M.; DASIEWICZ, K. Colour measurement as a method for the estimation of certain chicken meat quality indicators. Electronic Journal of Polish Agricultural Universities, Food Science and Technology, v.5, n.2, 2002. http://www.ejpau.media.pl (15 Mar. 2003)

FRONING, G.W.; BABJI, A.S.; MATHER, F.B. The effect of pre-slaughter temperature, stress, struggle and anesthetization on color and textural characteristics of turkey muscle. Poultry Science, v.57, n.3, p.630-633, 1978.

FRONING, G.W.; UIJTTENBOOGAART, T.G. The effect of post-mortem electrical stimulation on color, texture, $\mathrm{pH}$, and cooking lose of hot and cold deboned chicken broiler meat. Poultry Science, v.67, n.11, p.1536-1544, 1988.

FUJIMURA, S.; KOGA, H. TAKEDA, M.; TONE, N.; KADOWAKI, M.; ISHIBASHI, T. Role of taste-active components, blutamic acid, 5 inosinic acid and potassium ion in taste of chicken meat extract. Animal Science Technology, v.67, n.5, p.423-428, 1996.

GRAY, J.I.; PEARSON, A.M. Rancidity and warmed-over flavor. In: PEARSON, A.M.; DUTSON, T.R. (Ed.). Advances in meat research. New York: Van Nostrand Reinhold Company, 1987. p.221-270.

GREGORY, N.G. Stunning and slaughter. In: MEAD, G.C (Ed.). Processing of poultry. London: Elsevier Applied Science, 1989. p.31-63.

HOLOWNIA, K.; CHINNAN, M.S.; REYNOLDS, A.E. Pink color defect in poultry white meat as affected by endogenous conditions. Journal of Food Science, v.68, n.3, p.742-745, 2003.

HONIKEL, K.O.; HAMM, R. Über die Ursachen der Abnahme des pH-Wertes im Fleisch nach dem Schlachten. Fleischwirtschaft, v.54, n.3, p.557-560, 1974. 
HORNSTEIN, L.; CROWE, P.F.; SOLZBACHER, W.L. Flavour of beef and whale meat. Nature, v.199, n.25, 1252-1254, 1963.

JOLLY, D.D.; SCHUTZ, H.G.; DIAZ-KANAUF, K.V.; JOHAL. J. Organic food: consumer attitudes and use. Food Technology, v.43, n.11, p.60-66, 1989.

JONES, J.M.; GREY, T.C. Influence of processing on product quality and yield. In: MEAD, G.C. (Ed.). Processing of poultry. London: Elsevier Applied Science, 1989. p.127-130.

JUDGE, M.D.; ABERLE, E.D.; FORREST, J.C.; HEDRICK, H.B.; MERKEL, R.A. Principles of meat science. 2.ed. Dubuque: Kendall Hunt Publishers, 1989. 351p.

KANNAN, G.; HEATH, J.L.; WABECK, C.J.; SOUZA, M.C.P; HOWE, J.C.; MENCH, J.A. Effects of crating and transport on stress and meat quality characteristics in broilers. Poultry Science, v.76, n.3, p.523-529, 1997.

KAUFFMAM, R.G.; MARSH, B.B. Quality characteristic of muscle as a food. In: PRICE, J.F.; SCHWEIGERT, B.S. The science of meat and meat product. Connecticut: Food \& Nutrition Press, 1987. 639p.

KHAN, A.W. Effect of temperature during post-mortem glycolise and dephosphorylation of high energy phosphates on poultry meat tenderness. Journal of Food Science, v.36, n.1, p.120-121, 1971.

KLOSE, A.A.; SAYRE, R.N; POOL, M.F. Tenderness changes associated with cutting up poultry shortly after warm evisceration. Poultry Science, v.50, n.3, p. 585-591, 1971.

KNOWLES, T.G.; BROOM, D.M. The handling and transport of broilers and spent hens. Applied Animal Behavior Science, v.28, n.1-2, p.75-91, 1990.

KRANEN, R.W.; VAN KUPPEVELT, T.H.; GOEDHART, H.A.; VEERKAMP, C.M.; LAMBOOY, E.; VEERKAMP, J.H. Hemoglobin and mioglobin content in muscle of broiler chickens. Poultry Science, v.78, n.3, p.467-476, 1999. 
LACY, M.P.; CZARICK, M. Field testing of a mechanized broiler harvesting system. Poultry Science, v.73, p.41S, 1994. Supplement 1. /Apresentado ao 83. Annual Meeting, Starknille, 1994 - Abstracts/

LANGSLOW, D.R.; LEWIS, R.J. Alterations with age in compositions and lipolytic activity of adipose tissue from male and female chickens. British Poultry Science, v.15, n.3, p.267-273, 1974.

LEANDRO, N.S.M.; ROCHA, P.T.; STRINGHINI, J.H.; SCHAITL, M.; FORTES, R.M. Efeito do tipo de captura dos frangos de corte sobre a qualidade da carcaça. Ciência Animal Brasileira, v.2, n.2, p.97-100, 2001.

LEE, B.Y.; HARGUS, L.G.; HAGBERG, C.E.; FORSYTHE, R.H. Effect ante-mortem environmental temperatures on post-mortem glycolysis and tenderness in excised broiler breast muscle. Journal Food Science, v.41, n.4, p.1466-1469, 1976.

LEE, B.Y.; HARGUS, L.G.; WEBB, E.J.; RICKANSRUD, A.D.; HAGBERG, C.E. Effect of electrical stunning on post-mortem biochemical changes and tenderness in broiler breast muscle. Journal Food Science, v.44, n.4, p.1121-1122, 1979.

LI, Y.; SIEBENMORGEN, T.J.; GRIFFS, C.L. Electrical stimulation in poultry: A review and evaluation. Poultry Science, v.72, n.1, p.7-22, 1993.

LIGHT, N.D.; CHAMPION, A.E.; VOYLE, C.A.; BAILEY, A.J. The role of epimysal, perimysal and endomysal collagen in determining texture in six bovine muscles. Meat Science, v.13, n.3, p.137-149, 1985.

LINDSAY, R.C. Flavor volatiles in muscle foods. In: FENEMA, O.R. (Ed.). 2.ed. Food chemistry. New York: Marcel Dekker, 1985. p.612-613.

LIU, A.; NISHIMURA, T.; TAKAHASHI, K. Relationship between structural properties of intramuscular connective tissue and toughness of various chicken skeletal muscle. Meat Science, v.43, n.1, p.43-49, 1996. 
LIU, Y.; LYON, B. G.; WINDHAM, W. R.; LYON, C. E.; SAVAGE, E. M. Principal component analysis of physical, color and sensory characteristic of chicken breast deboned at two, four, six and twenty-four hours post-mortem. Poultry Science, v.83, n.1, p.101-108, 2004.

LYON, B.G.; LYON, C.E. Texture profile of broiler pectoralis major as influenced by post-mortem deboning time and heat method. Poultry Science, v.69, n.2, p.329-340, 1990a.

LYON, B.G.; LYON, C.E. The relationship of objective shear values and sensory tests to changes in tenderness of broiler breast meat. Poultry Science, v.69, n.8, p.1420$1427,1990 b$.

LYON, B.G.; LYON, C.E. Sensory descriptive profile relationship to shear values of deboned poultry. Journal Food Science, v.62, n.4, p.885-888, 1997.

LYON, B.G.; SMITH, D.P.; LYON C.E.; SAVAGE, E.M. Effect of diet and feed withdrawal on the sensory descriptive and instrumental profiles of broiler breast fillets. Poultry Science, v.83, n.2, p.275-281, 2004.

LYON, C.E.; HAMM, D.; THOMSON, J.E. pH and tenderness of broiler breast meat deboned various times after chilling. Poultry Science, v.64, n.2, p.307-310, 1985.

LYON, C.E.; PAPA, C.M.; WILSON Jr., R.C. Effect of feed withdrawal on yield, muscle, $\mathrm{pH}$ and texture of broiler breast meat. Poultry Science, v.70, n.4, p.10201025, 1991.

LYON, C.E.; LYON, B.G.; PAPA, C.M.; ROBACH, M.C. Broiler tenderness effects of post-chill deboning time and fillet holding time. Journal Applied Poultry Research, v.1, n.1, p.27-32, 1992.

MA, R.T.; ADDIS, P.B. The association of struggle during exsanguinations to glicolysis, protein solubility and shear in turkey pectoralis muscle. Journal Food Science, v.38, n.6, p.995-997, 1973. 
MAKI, A.; FRONING, G.W. Effect of post-mortem electrical stimulation on quality of turkey meat. Poultry Science, v.66, n.7, p.1155-1157, 1987.

MAURER, J.A. Color and color problems in poultry carcasses and products. http://www.cvm.umn.edu/avian/sfpc/colorproblems.html (10 Oct. 2000)

MAYES, F.J. The incidence of bruising in broiler flocks. British Poultry Science, v.21, n.2, p.505-509, 1980.

MC CURDY, R.; BARBUT, S.; QUINTON, M. Sensorial effects on PSE in young turkey breast meat. Food Research International, v.29, n.3-4, p.363-366, 1996.

MCKEE, S.R.; HIRSCHLER, E.M.; SAMS, A.R. Physical and biochemical effects of broiler breast tenderization by aging after pre-rigor deboning. Poultry Science, v.62, n.5, p.959-962, 1997.

MEAD, G.S. Recommendation for a standardized method of sensory analysis for broilers. World’s Poultry Science Journal, v.43, n.1, p.64-67, 1987.

MEEK, K.I.; CLAUS, J.R.; DUNEAN, S.E.; MARRIOTT, N.G.; SOLOMON, M.B.; KATHMAN, S.J.; MARINI, M.E. Quality and sensory characteristics of selected post-rigor, early-deboned broiler breast meat tenderized using hydrodynamic shock waves. Poultry Science, v.79, n.1, p.126-136, 2000.

MELTON, S.L. Methodology for following lipid oxidation in muscle foods. Food Technology, v.37, n.7, p.105-111, 1983.

MENDES, A.A. Rendimento e qualidade da carcaça de frangos de corte. In: CONFERENCIA APINCO DE CIÊNCIA E TECNOLOGIA AVÍCOLAS, Campinas, 2001. Anais. Campinas: FACTA, 2001. p.79-99.

MORAES, M.A.C. Métodos para avaliação sensorial dos alimentos. Campinas: UNICAMP, 1983. 61p.

NAKAMURA, M.; KATOH, K. Influence of thawing method on several properties of rabbit meat. Bulletin of Ishika Prefecture College of Agriculture, v.11, n.1, p.4549, 1985. 
NORTHCUTT, K. Factors affecting poultry meat quality. Athens: The University of Georgia, Department of Poultry Science, 1997. 7p. (Bulletin of Poultry Science, 1157).

NORTHCUTT, J.K.; FOEGEDING, E.A.; EDENS, F.W. Water-holding properties of thermally preconditioned chicken breast and leg meat. Poultry Science, v.73, n.2, p.308-316, 1994.

OLIVO, R. Carne PSE em frangos. São Paulo, 1999. 97p. Tese (Doutorado) - Faculdade de Ciência Farmacêuticas, Universidade de São Paulo.

PINTO, A.A.; SOUSA, G.L.; ALVARADO, M.B.H.; CONTRERAS, C.J.C.; ORTEGA, E.M.M. Efeito do tempo de jejum pré-abate no rendimento de carcaça de frango criados no sistema alternativo (compact disc). In: CONGRESSO BRASILEIRO DE CIÊNCIA E TECNOLOGIA DE ALIMENTO: Estratégia para o desenvolvimento, 19., Recife, 2004. Anais. Recife: CBCTA, 2004

POLIDORI, P.; TRABALZA-MARINUCCI, M.; RENIERI, C.; POLIDORI, F. Ocurrence of pale, soft, exudative (PSE) meal in broiler chickens. In: THE AMERICAN SERVICE MEMBERS PROTECTION ACT CONGRESS, 13., Piacenza, 1999. Proceedings. Piacenza: s. ed., 1999. p.728-730.

POLIDORI, P.; TRABALZA-MARINUCCI, M.; FANTUZ, F.; RENIERI, C.; POLIDORI, F. Pale, soft and exudative (PSE) meat in broiler chickens: characteristics and assessment methods. Industries Alimentaires, v.39, n.2, p.326$331,2000$.

PRICE, J.F.; SCHWIEGERT, B.S. Ciencia de la carne y de los productos cárnicos. 2.ed. Zaragoza: Acribia, 1994. 581p.

QIAO, M.; FLETCHER, D.L; NORTHCUTT, J.K.; SMITH, D.P. The relationship between raw broiler breast meat color and cow position. Poultry Science, v.81, n.3, p.422-427, 2002. 
QIAO, M.; FLETCHER, D.L; SMITH, D.P.; NORTHCUTT, J.K. The effect of broiler breast meat color on $\mathrm{pH}$, moisture, water-holding capacity, and emulsification capacity. Poultry Science, v.80, n.5, p.676-680, 2001.

RASMUSSEN, A.L.; MAST, M.G. Effect of feed withdrawal on composition and quality of broiler meat. Poultry Science, v.68, n.8, p.1109-1113, 1989.

REALI, M.H. Manejo de frangos. Campinas: FACTA, 1994. p.103-108: Fatores que afetam o rendimento e a qualidade da carcaça.

RHEE, K.S.; ANDERSON, L.M.; SAMS A.R. Lipid oxidation potencial of beef, chicken and pork. Journal of Food Science, v.61, n.1, p.8-12, 1996.

SAMS, A.R. Electrical stimulation and high temperature conditioning of broiler carcasses. Poultry Science, v.69, n.10, p.1781-1786, 1990.

SAMS, A.R. Meat quality during processing. Poultry Science, v.78, n.5, p.798-803, 1999.

SAMS, A.R. Poultry meat processing. Boca Raton: CRC Press, 2001. 334p.

SAMS, A.R.; MILLS, K.A. The effect of feed withdrawal duration on the responsiveness of broiler pectoralis to rigor acceleration. Poultry Science, v.72, n.9, p.1789-1796, 1993.

SAMS, A.R.; BIRKHOLD, S.G.; MILLS, K.A. Fragmentation and tenderness of breast muscle from broiler carcasses treated with electrical stimulation and high temperatures conditioning. Poultry Science, v.70, n.6, p.1430-1433, 1991.

SAMS, A.R.; JANKY, D.M.; WOODWARD, S.A. Tenderness and R-value changes in early harvested broiler breast tissue following post-mortem electrical stimulation. Poultry Science, v.68, n.9, p.1232-1235, 1989.

SANDUSKY, C.L.; HEATH, J.L. Sensory and instrument-measured ground chicken meat color. Poultry Science, v.77, n.3, p.481-486, 1998. 
SANTOS, C.L.C; ROSERIO, H.; CONCALVES, H.; MELO, R.S. Incidence of different pork quality categories in a portuguese slaughter house: a survey. Meat Science, v.38, n.2, p.279-287, 1994.

SANTOS, H.C.; BANDELLI, A.; AYUB, M.A.Z. Influence of post-mortem aging in tenderness of chicken breast fillets. Ciência Rural, v.34, n.3, p.905-910, 2004.

SCHEREURS, F.J.G. Post-mortem changes in chicken muscle. Would Poultry Science Journal, v.56, n.4, p.319-346, 2000.

SCHOLTYSSEK, S.; EHINGER, F. Transportein flüsse aut broiler und deren schlachtkörper. Archiv Geflügelkd, v.40, n.1, p.27-35, 1976.

SEU $\beta$, I. Valor nutricional de la carne y de los productos cárnicos. Consideraciones críticas sobre sus componentes en comparación con otros alimentos. Fleischwirtsch, n.1, p.47-50, 1991.

SIMPSON, M.D.; GOODWIN, T.L. Comparison between shear values and test panel score for predicting tenderness of broiler. Poultry Science, v.53, n.6, p.2042-2046, 1974.

SIMS, T.J.L; BAILEY, A.J. Connective tissue In: LAWRIE, R. (Ed.). Development meat science. London: Applied Science Publishers, 1981. v.2, p.29.

SMITH, D.P.; ACTON, J.C. Marination, cooking, and curing of poultry products. In: SAMS, A.R. (Ed.). Poultry meat processing. Boca Raton: CRC Press, 2001. p. 257279.

SMITH, D.P.; FLETCHER, D.L.; PAPA, C.M. Duckling and chicken processing yield and breast meat tenderness. Poultry Science, v.71, n.1, p.197-202, 1992a.

SMITH, D.P.; FLETCHER, D.L.; PAPA, C.M. Post-mortem biochemistry of pecking duckling and broiler chicken pectoralis muscle. Poultry Science, v.71, n.10, p.1768$1772,1992 b$. 
SMITH, N.B.; CANNON, J.E.; NOVAKOFSKI, J.E.; MCKEITH, F.K; O'BRIEN, W.D. Tenderization of semitendinosus muscle using high intensity ultrasound. In: ULTRASONICS SYMPOSIUM, Lake Buena Vista, 1991. Proceedings. Lake Buena Vista: IEEE Members and Publication Subscribers, 1991. p.1371-1373.

SOSNICKI, A.A.; WILSON, B.W. Pathology of turkey skeletal muscle: implications for the poultry industry. Food Structure, v.10, n.4, p.317-326, 1991.

SPANIER, A.M.; VINCENT EDWARDS, J.; DUPUY, H.P. The warmed-over flavor process in beef: a study of meal proteins and peptides. Food Technology, v.46, n.6, p.110-118, 1988.

STADELMAN, W.J.; OLSON, V.M.; SHEMWELL, G.A.; PASCH, S. Eggs and poultry-meat processing. New York: VCH Publishers, 1989. 211p.

St TANGELO, A.J.; VERCELlOTTI, J.R.; LEGENDRE, M.G.; VINNETT, C.H.; KUAN, J.W.; JAMES Jr., C.; DUPUY, H.P. Chemical and instrumental analysis of warmed-over flavour in beef. Journal of Food Science, v.52, n.4, p.1163-1168, 1987.

STEWART, M.K.; FLETCHER, D.L.;HAMM, D.; THOMSON, J.E. The influence of hot boning broiler breast muscle on $\mathrm{pH}$ decline and toughening. Poultry Science, v.63, n.10, p.1935-1939, 1984.

SUNDRUM, A. Organic livestock farming. A critical Review. Livestock production Science, v.67, n.3, p.207-215, 2001.

SWATLAND, H.J. Objective assessment of meat yield and quality. Trends in Food Science and Technology, v.6, n.4, p.117-120, 1995.

TAKAHASHI, K. Structural weakening of skeletal muscle tissue during post-mortem ageing of meat: The non-enzymatic mechanism of meat tenderization. Meat Science, v.43, supplement 1, p.67S-80S, 1996. 
THOMPSOM, J.E.; LYON, C.E.; HAMM, D.; DICKENS, J.A.; FLECTHER, D.L.; SHACKELFORD, A.D. Effect of electrical stunning and boning on broiler breast meat quality. Poultry Science, v.65, n.9, p.1715-1719, 1986.

TICHIVANGANA, J.Z.; MORRISEY, P.A. The influence of $\mathrm{pH}$ on lipid oxidation in cooked meats from several species. Irish Journal of Food Science and Technology, v.9, n.1, p.99-106, 1985.

VALLE, J.C.V. O mercado para frango orgânico. Agroecologia Hoje, v.3, n.18, p.25, jan./fev., 2003.

VAN LAACK, R.L.J.M.; VAN, LIU C.H.; SMITH, M.O.; LOVEDAY, H.D. Characteristics of pale, soft, exudative broiler breast meat. Poultry Science, v.79, n.7, p.1057-1061, 2000.

VARMAM, A.H.; SUTHERLAND, J.P. Carne y productos cárneos. Zaragoza: Acribia, 1998. 423p.

VIEIRA, S.L. Conceitos atuais de qualidade em produtos de frango: efeito da nutrição na fase inicial. In: SIMPÓSIO INTERNACIONAL DE TECNOLOGIA, PROCESSAMENTO E QUALIDADE DA CARNE DE AVES, Concórdia, 1999. Anais. Concordia: Embrapa, 1999. p.60-68.

VIEIRA, S.L.; MORAN Jr., E.T. Broiler yield using chicks from egg weight extremes and diverse strains. Journal of Applied Poultry Research, v.7, n.3, p.339-346, 1998.

WARRIS, P.D.; BEVIS, E.A.; BROWN, S.N.; EDWARDS, J.E. Longer journeys to processing plant are associated with higher mortality in broiler chickens. British Poultry Science, v.33, n.1, p.201-206, 1992.

WARRIS, P.D.; BROWN, S.N. The relationship between initial $\mathrm{pH}$, reflectance and exudation in pig muscle. Meat Science, v.20, n.1, p.65-72, 1987. 
WATTANACHANT, S.; BENJAKUL, S.; LEDWARD, D.A. Composition, color and texture of Thai Indigenous and broiler chicken muscle. Poultry Science, v.83, n.1, p.123-128, 2004.

WILLIAMS, S.K.; DAMRON, B.L. Sensory and objective characteristic of broiler meat from commercial broilers fed rendered whole-hen meal. Poultry Science, v.77, n.2, p.329-333, 1998a.

WILLIAMS, S.K.; DAMRON, B.L. Sensory and objective characteristic of broiler meat from commercial broilers fed rendered whole-spent hen meal. Poultry Science, v.77, n.9, p.1441-1445, 1998 b.

WOOD, D.F.; RICHARDS, J.F. Effect of some ante-mortem stressors on post-mortem aspects of chickens broiler pectoralis muscle. Poultry Science, v.54, n.2, p.528-531, 1975.

WOOLFEL, R.L.; OWENS, C.M.; HIRSCHLER, E.M.; MARTINEZ-DRAWSON, R.; SAMS, A.R. The characterization and incidence of pale, soft, and exudative broiler meat in a commercial processing plant. Poultry Science, v.81, n.4, p.579-584, 2002.

YANG, C.C.; CHEN, T.C. Effect of refrigerated store, $\mathrm{pH}$ adjustment, and marinates on color of raw and microwave cooked chicken meat. Poultry Science, v.72, n.2, p.355-362, 1993.

YOUNG, L.L.; LYON, C.E. Effect of post-chill and sodium tripolyphosphate on moisture binding properties, color, and Warner Bratlzer shear values of chicken breast meat. Poultry Science, v.78, n.11, p.1587-1590, 1997. 